\title{
Environmental Isotope Investigation of Groundwater Flow in the Honey Lake Basin, California and Nevada
}

\author{
Timothy P. Rose \\ M. Lee Davisson \\ G. Bryant Hudson \\ Angela R. Varian
}

July 1997

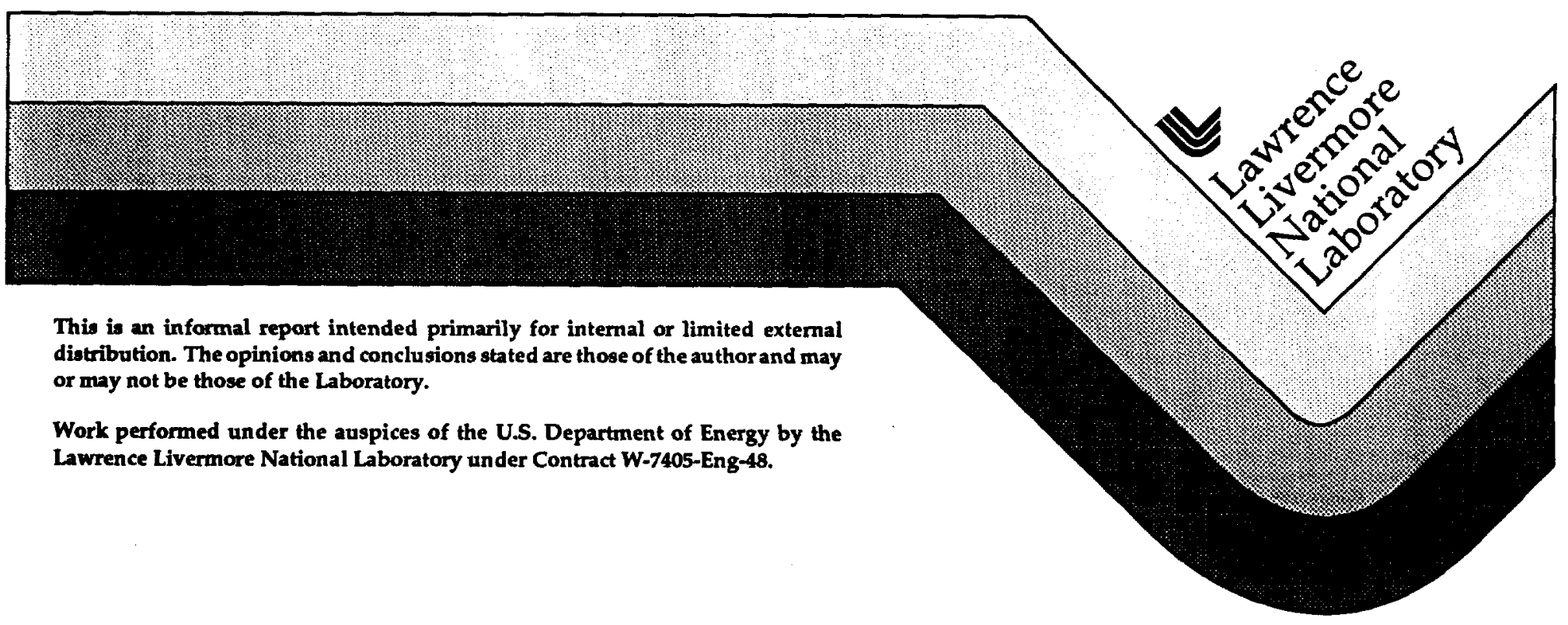




\section{DISCLAIMER}

This document was prepared as an account of work sponsored by an agency of the United States Government. Neither the United States Government nor the University of California nor any of their employees, makes any warranty, express or implied, or assumes any legal liability or responsibility for the accuracy, completeness, or usefulness of any information, apparatus, product, or process disclosed, or represents that its use would not infringe privately owned rights. Reference herein to any specific commercial products, proces, or service by trade mame, trademark, manufacturer, or otherwise, does not necessarily constitute or imply its endorsement, recommendation, or favoring by the United States Government or the University of California. The views and opinions of authors expressed herein do not necessarily state or reflect those of the United States Government or the University of Californiz, and shall not be used for advertising or product endorsement purposes.

This report has been reproduced directly from the best available copy.

Available to DOE and DOE contractors from the Ofrice of Scientific and Technical Information P.O. Box 62, Oak Ridge, TN 37831

Prices available from (615) 576-8401, FTS 626-8401

Available to the public from the

National Technical Information Service

U.S. Department of Commerce 5285 Port Royal Rd. Springfield, VA 22161 


\title{
Environmental Isotope Investigation of Groundwater Flow in the Honey Lake Basin, California and Nevada
}

\author{
Timothy P. Rose \\ M. Lee Davisson \\ G. Bryant Hudson \\ Isotope Sciences Division \\ Lawrence Livermore National Laboratory \\ Livermore, CA 94550 \\ and \\ Angela R. Varian \\ U.S. Army Corps of Engineers \\ Sacramento District \\ Sierra Army Depot Field Office \\ Herlong, CA 96113
}

July, 1997 


\section{Executive Summary}

The hydrology of Honey Lake Basin was studied using environmental isotope measurements of approximately 130 water samples collected during 1995 and 1996. The principal analytical methods included hydrogen, oxygen and carbon stable isotope ratio measurements, radiocarbon and tritium dating, and measurements of dissolved noble gas abundances. The main conclusions are as follows.

- Isotopic and chemical data are consistent with groundwater discharge within an evapotranspiration zone along the central axis of the basin. Evidence includes: (1) relatively old ${ }^{14} \mathrm{C}$ ages at shallow depths; (2) moderately evaporated $\delta^{18} \mathrm{O}-\delta \mathrm{D}$ signatures in shallow groundwaters from this area; and (3) correspondingly high electrical conductivities in the evaporated groundwaters.

- Annual runoff and precipitation from the Sierra Nevada (Diamond Mountains) is not a source of groundwater recharge east of the Warm Springs fault. Modern recharge in the eastern half of the basin is provided only by seasonal precipitation and infiltration of runoff from the eastem Fort Sage, Virginia and Skedaddle Mountains. Hence, recharge rates are quite low in the eastern basin. Northwest of Honey Lake (in the Susanville area) groundwater recharge originates in the Sierra Nevada, and from north of latitude $40^{\circ} 30^{\prime} \mathrm{N}$, in the Willow Creek drainage basin.

- Fault zones have created impermeable barriers to lateral groundwater flow in parts of the basin. This is particularly evident in the Herlong area, where a hidden segment of the Warm Springs fault zone separates older groundwater to the east from younger groundwater to the west. Groundwaters from deep wells on the east side of this fault have ${ }^{14} \mathrm{C}$ ages in excess of 16,000 years. West of the fault, the maximum ${ }^{14} \mathrm{C}$ ages are less than 8,000 years. 
Significant differences are also observed in the stable isotope compositions and noble gasderived recharge temperatures on either side of the Warm Springs fault. The combined isotope data suggest that deep groundwater east of the fault was recharged during colder climatic conditions that existed in this area between 12,000 and 19,000 years ago. At depths $<200$ feet, groundwaters east of the Warm Springs fault show a range in ${ }^{14} \mathrm{C}$ ages from 2400 to 12,000 years due to shallow mixing of younger water with older groundwater ascending under hydraulic head into the discharge area.

- Only two groundwater samples were observed to contain tritium at concentrations above the background level. Both of these samples are from the Long Valley area. The lack of tritium in other groundwater samples indicates that modern recharge ( $<45$ years) is not present in detectable amounts in many of the wells.

- Estimated recharge rates based on groundwater ${ }^{14} \mathrm{C}$ data suggest a range of values between 45,000 and 60,000 ac- $\mathrm{ft} \mathrm{yr}^{-1}$ for the entire basin. This range of values is

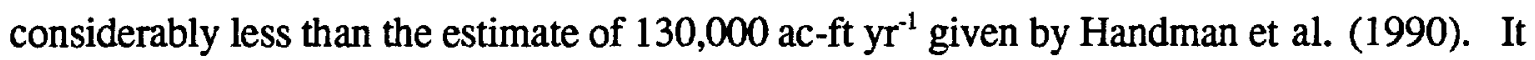
should be emphasized that recharge is not uniform across the basin. The highest recharge rates occur in the western part of the basin, where precipitation rates are the greatest. Estimated recharge rates along the base of the Sierra Nevada range are on the order of 17,000 to 23,000 ac-ft $\mathrm{yr}^{-1}$.

- The effect of intensive groundwater pumping in the eastern half of the basin would be equivalent to groundwater "mining" since the majority of the groundwater in this region has old ${ }^{14} \mathrm{C}$ ages. Moreover, prolonged pumping would be expected to induce the migration of contaminants that currently reside in shallow groundwater within the boundaries of the Sierra Army Depot. 


\section{Introduction}

Honey Lake Basin is a $5700 \mathrm{~km}^{2}$ closed alluvial basin located in the semi-arid high desert $\sim 100 \mathrm{~km}$ northwest of Reno, Nevada. The proposed development of production wells to augment the municipal water supply for Reno provided the impetus for several recent studies aimed at understanding the hydrogeology and availability of water resources in the basin (e.g. Handman et al., 1990; Rockwell, 1990; Bohm, 1990; Stone et al., 1990). Two central issues must be addressed with regard to water resource development in this region. First, the rate at which the aquifer is recharged must be evaluated in order to determine how much groundwater withdrawal the basin can sustain before serious overdrafting occurs. Second, there is a question as to whether intensive groundwater pumping will induce the migration of contaminants residing in shallow groundwaters beneath the Sierra Army Depot, on the eastern side of Honey Lake (see Figure 1).

This study was undertaken in cooperation with the Sierra Army Depot to evaluate these questions using environmental isotope tracer methods. Environmental isotopes permit quantitative determinations of the origin, age and flow paths of groundwaters on a regional scale (see reviews by Fontes, 1980; Mook, 1980; Mazor, 1991). Whereas conventional hydrologic studies are concerned with determining the water transport properties of porous media, environmental isotope studies focus on measuring properties that are intrinsic to the water itself. Hence, the two methods provide complimentary data that can be combined to generate well constrained models for hydrologic systems.

The principal objectives of this study are to (1) identify the sources of recharge to the basin, (2) determine the age distribution of groundwater in the basin, and (3) estimate the rate at which groundwater recharge occurs. 


\section{Hydrogeologic Setting}

Honey Lake Basin is a northwest trending structural depression approximately $125 \mathrm{~km}$ long by $60 \mathrm{~km}$ wide, with a total drainage area of approximately $5700 \mathrm{~km}^{2}\left(2200 \mathrm{mi}^{2}\right)$ (Rockwell, 1990). It is located near the northern terminus of the Walker Lane shear zone, along the boundary between the Basin and Range extensional province and the northern Sierra Nevada batholith (Stewart, 1988). The basin is transected by a series of northweststriking normal and right-lateral transcurrent faults (Figure 1) that have been active since at least mid-Miocene time (Roberts, 1985). The principal geologic units in the region consist of Cretaceous granites exposed in the Sierra Nevada (Diamond Mountains) and Fort Sage Mountains, Tertiary volcanic rocks exposed in the northern and eastern parts of the basin, and Plio-Pleistocene fluvial and lacustrine basin-fill deposits (Bonham, 1969; Roberts, 1985; Grose et al., 1990). Granitic bedrock, displaced downward along faults, forms the lower boundary for most groundwater flow in the basin, with the depth to bedrock generally increasing along strike toward the northeast (Handman et al., 1990). The basin-fill aquifer consists of unconsolidated and semiconsolidated clastic sediments and pyroclastic rocks that reach a maximum thickness of $>1500 \mathrm{~m}(5000 \mathrm{ft})$ in the northeastern part of the basin (Handman et al., 1990).

The dominant source of groundwater recharge is from precipitation and streamflow infiltration in upland areas. Groundwater flows down gradient from recharge areas in or near the mountains to discharge areas near the central axis of the basin (Handman et al., 1990). Mean annual precipitation rates range from $<10 \mathrm{~cm} \mathrm{yr}^{-1}\left(<4\right.$ in $\left.\mathrm{yr}^{-1}\right)$ in the eastcentral basin to $>50 \mathrm{~cm} \mathrm{yr}^{-1}\left(>20\right.$ in $\left.\mathrm{yr}^{-1}\right)$ in the Sierra Nevada (Rantz, 1969). Mass balance calculations by Handman et al. (1990) suggest that $90 \%$ of the water entering the basin each year is lost to runoff, evaporation and transpiration. The remaining $10 \%$, approximately $1.60 \times 10^{8} \mathrm{~m}^{3} \mathrm{yr}^{-1}\left(130,000\right.$ acre- $\left.\mathrm{ft} \mathrm{yr}^{-1}\right)$, recharges the aquifer system. The groundwater recharge rate is balanced by an approximately equal amount of groundwater discharge, primarily as evapotranspiration and withdrawals from wells (Handman et al., 1990). 
Thermal waters in the northeastern part of the basin are exploited for geothermal energy (Juncal and Bohm, 1987).

The largest streams in the study area are the Susan River, Willow Creek and Long Valley Creek (Figure 1). Other streams are intermittent and reach the valley floor only in wet years. The water level in Honey Lake fluctuates considerably, occasionally going dry during extended periods of drought. On average, Honey Lake has a surface area of about $190 \mathrm{~km}^{2}\left(47,000\right.$ acres) and contains about $1.48 \times 10^{8} \mathrm{~m}^{3}(120,000$ acre-ft) of water (Rockwell, 1990; Handman et al., 1990). Honey Lake occupies an area previously covered by one lobe of Pleistocene Lake Lahontan, which achieved a high stand between 14,000 and 12,500 years ago that was approximately 115 meters ( 380 feet) above the present-day level of Honey Lake (Benson and Mifflin, 1986; Benson et al., 1990).

\section{Sampling and Analytical Methods}

Water samples were collected during 1995 and 1996 from wells, springs, surface runoff, and precipitation events. Sample sites are reported as township, range and section locations in Tables 1 and 2. Map locations are shown in Figures 4, 8 and 9. Stable isotope and tritium samples were collected in glass bottles with air tight seals to prevent atmospheric exchange. Samples collected for carbon isotopic analysis were treated with a few drops of saturated $\mathrm{HgCl}_{2}$ solution to kill any biological activity in the water. Dissolved inorganic carbon (DIC) is extracted by acidifying the sample with $100 \% \mathrm{H}_{3} \mathrm{PO}_{4}$ under vacuum and cryogenically trapping the evolved $\mathrm{CO}_{2}$ gas (McNichol et al., 1994). The $\mathrm{CO}_{2}$ sample is split, and the aliqout intended for ${ }^{14} \mathrm{C}$ measurement is reduced to graphite by reaction with hydrogen gas at $570^{\circ} \mathrm{C}$ in the presence of a cobalt metal catalyst, followed by analysis on the accelerator mass spectrometer at Lawrence Livermore National Laboratory (Vogel et al., 1987). The remaining $\mathrm{CO}_{2}$ is analyzed for $\delta^{13} \mathrm{C}$. The ${ }^{14} \mathrm{C}$ results are reported as percent modem ${ }^{14} \mathrm{C}$ relative to a NBS OX-1 standard that represents prenuclear testing atmospheric $\mathrm{CO}_{2}$ abundances (Stuiver and Polach, 1977). The analytical precision is \pm 1 percent modem 
carbon (pmc). Apparent ages are calculated using a ${ }^{14} \mathrm{C}$ half life of 5730 years (Walker et al., 1989).

Waters were analyzed for their oxygen and hydrogen isotope ratios using the water- $\mathrm{CO}_{2}$ equilibration (Epstein and Mayeda, 1953) and zinc-reduction techniques (Coleman et al., 1982), respectively, followed by analysis on an isotope ratio mass spectrometer. Oxygen, hydrogen and carbon stable isotope analyses are reported in the usual delta $(\delta)$ notation as per mil deviations from SMOW (oxygen and hydrogen) or PDB (carbon) reference standards, as appropriate (e.g. Criss, 1995). Analytical precision is $\pm 0.1 \%$ for $\delta^{18} \mathrm{O}$, $\pm 0.3 \%$ for $\delta^{13} \mathrm{C}$, and $\pm 1 \%$ for $\delta \mathrm{D}$.

Tritium was analyzed by the helium-accumulation method (Surano et al., 1992) wherein water samples are cryogenically degassed, sealed, and stored for 15-60 days to allow the accumulation of ${ }^{3} \mathrm{He}$ from tritium decay. The sample is subsequently degassed and the ${ }^{3} \mathrm{He}$ is isolated and measured on a noble gas mass spectrometer. The analytical precision is approximately $\pm 0.5 \mathrm{TU}$ or better.

Noble gas samples are collected in 3/8" copper tubes with pinch clamp assemblies that seal the water sample free of any gas bubbles. In the laboratory, the copper tubes are vacuum fitted to an evacuated container, the cold seal is uncrimped, and the water sample is released into an evacuated container. The sample is subsequently degassed and the noble gases are isolated and analyzed on a noble gas mass spectrometer. Calculated noble gas recharge temperatures are accurate to less than $\pm 1^{\circ} \mathrm{C}$.

\section{Results and Discussion}

\subsection{Aqueous Chemistry}

Alkalinity, conductivity, $\mathrm{pH}$ and temperature measurements of waters were routinely determined in the field during sample collection. Dissolved inorganic carbon (DIC), reported in parts per million (ppm) as bicarbonate ion, was determined in the laboratory as part of the carbon isotope analytical procedure. Results are presented in Tables 1 and 2. 
Total alkalinity is defined as the equivalent sum of the bases that are titratable with a strong acid (Stumm and Morgan, 1981). Since the $\mathrm{pH}$ of most natural waters is near neutral, the hydrogen and hydroxyl ion concentrations are generally very small compared to those of bicarbonate and carbonate (Drever, 1982). Under these conditions, the total alkalinity is approximately equal to the carbonate alkalinity (reported as ppm $\mathrm{CaCO}_{3}$ ). For the observed range of $\mathrm{pH}$ values in Honey Lake Basin waters $(\mathrm{pH}=6.7$ to 9.7), the bicarbonate ion is the dominant DIC species. Differences in alkalinity and DIC values primarily reflect inaccuracies in the alkalinity field test procedure. In addition, waters with $\mathrm{pH}$ values $\leq 7.5$ contain the neutral species $\mathrm{H}_{2} \mathrm{CO}_{3}$, which does not influence alkalinity, but contributes to the measured DIC concentration.

Conductivity (or electrical conductance) measures the ability of a water to conduct an electric current. As ion concentrations increase, the conductivity of the solution increases. Conductivity measurements therefore provide an approximate indication of the dissolved ion concentration in the water (Hem, 1985). Conductivity values are reported in units of microsiemens per centimeter $\left(\mu \mathrm{S} \mathrm{cm}^{-1}\right)$.

Figure 2 shows the variation in alkalinity versus conductivity in Honey Lake Basin waters. Most springs and surface waters plot in the lower left comer of the graph with alkalinity and conductivity values $<180 \mathrm{ppm}$ and $<500 \mu \mathrm{S} \mathrm{cm} \mathrm{c}^{-1}$, respectively. The approximately linear increase in conductivity with alkalinity in these samples indicates that DIC is the predominant dissolved anion. This is consistent with data reported by Webber (1996) that shows springs and streams in Honey Lake Basin contain $\mathrm{HCO}_{3}$ anions with variable amounts of $\mathrm{Ca}, \mathrm{Na}$, and $\mathrm{Mg}$ cations. Higher concentrations of total dissolved solids (reflected by higher conductivity and alkalinity values) indicate increasing evapotranspiration or water-rock interaction.

The groundwater data in Figure 2 shows considerable scatter, with alkalinity values up to $500 \mathrm{ppm}$ and conductivity values as high as $2660 \mu \mathrm{S} \mathrm{cm}^{-1}$. Concentrations increase toward the center of the basin, with the highest values observed in shallow groundwaters in 
the vicinity of the Sierra Army Depot. In this region, groundwater rises toward the surface under hydraulic head and undergoes evapotranspiration, causing a gradual build up of dissolved solids in the shallow aquifer (Handman et al., 1990). Webber (1996) notes that shallow groundwaters evolve in their chemistry from relatively fresh $\mathrm{Na}-\mathrm{Ca}-\mathrm{HCO}_{3}$ type waters at the valley margin to saline $\mathrm{Na}-\mathrm{Cl}$ dominated waters on the valley floor.

Deep geothermal waters with temperatures near $100^{\circ} \mathrm{C}$ have relatively low alkalinity values, reflecting the decreased solubility of $\mathrm{CaCO}_{3}$ at elevated temperatures (Plummer and Busenberg, 1982). The high conductivity of these waters is due to high levels of $\mathrm{Na}, \mathrm{SO}_{4}$ and $\mathrm{Cl}$ (Webber, 1996), reflecting elevated temperatures and increased water-rock interaction.

\subsection{Oxygen and Hydrogen Isotopes}

The stable isotope ratios of oxygen $\left({ }^{18} \mathrm{O} /{ }^{16} \mathrm{O}\right)$ and hydrogen $\left({ }^{2} \mathrm{H} /{ }^{1} \mathrm{H}\right.$ or $\left.\mathrm{D} / \mathrm{H}\right)$ show systematic variations in hydrologic systems that can be used to trace the origin and transport pathways of different water masses. Oxygen and hydrogen isotope measurements are reported as $\delta$-values, representing the per mil (\%o, or parts per thousand) difference in the isotope ratio of a sample $(\mathrm{x})$ relative to a reference standard (std):

$$
\delta=1000\left[\left(R_{\alpha} / R_{s t d}\right)-1\right]
$$

where $\mathrm{R}$ refers to the appropriate isotope ratio $\left({ }^{18} \mathrm{O} /{ }^{16} \mathrm{O}\right.$ or $\left.\mathrm{D} / \mathrm{H}\right)$. The internationally accepted standard for $\delta^{18} \mathrm{O}$ and $\delta \mathrm{D}$ analyses of waters is Standard Mean Ocean Water (SMOW), which represents the average isotopic composition of the world's oceans. In general, meteoric waters from continental interiors have negative $\delta$-values because they contain a lower abundance of the heavy isotopes $\left({ }^{18} \mathrm{O}\right.$ or $\left.\mathrm{D}\right)$ relative to the ocean.

The $\delta^{18} \mathrm{O}$ and $\delta \mathrm{D}$ values of precipitation are strongly dependent on temperature, and vary with latitude, elevation and distance from the ocean (Dansgaard, 1964). Most large storm systems originate over the ocean. However, when a storm moves inland, the removal 
of precipitation gradually depletes the system of its heavy isotopes (e.g. Ingraham and Taylor, 1991). Water molecules are partitioned between the vapor (cloud) and liquid (raindrop) according to differences in mass. Molecules containing heavy isotopes have a greater tendency to go into the liquid phase, whereas molecules containing light isotopes tend to remain in the vapor. This process is referred to as isotopic fractionation. In general, cooler temperatures produce larger fractionation effects. For example, as a saturated air mass rises up a mountain range and cools, the $\delta^{18} \mathrm{O}$ and $\delta \mathrm{D}$ values of its precipitation decrease with increasing altitude. These isotopic signatures are preserved once the precipitation infiltrates to the saturated groundwater zone. It is therefore possible to use $\delta^{18} \mathrm{O}$ and $\delta \mathrm{D}$ values to establish the recharge location for a groundwater, particularly in areas with significant topographic relief.

Evaporation processes also fractionate the oxygen and hydrogen isotope ratios in water. This effect is readily observed in standing bodies of water where evaporation progressively enriches the remaining water in heavy isotopes. Using a combination of $\delta^{18} \mathrm{O}$ and $\delta \mathrm{D}$ measurements, the secondary effect of evaporation is easily distinguished from the primary precipitation signature.

The $\delta^{18} \mathrm{O}$ and $\delta \mathrm{D}$ values of approximately 130 water samples were measured during this study. Precipitation, surface runoff, and spring water isotopic values are useful indicators of modern groundwater recharge compositions. Regional variations in these recharge components can be used to constrain the origin of young groundwater masses. The following sections describe the observed stable isotope variations in recharge, followed by a comparison of these data with groundwater isotope data in order to deduce modem recharge sources. 


\subsection{1 $\delta^{18} O$ and $\delta D$ in Precipitation}

The dominant sources of groundwater recharge in the Honey Lake region are: (1) infiltration of runoff during spring melting of mountain snowpacks, and (2) direct infiltration of precipitation. Precipitation rates are highest in the western part of the basin, along the crest of the Sierra Nevada. Precipitation rates decrease dramatically to the east of the Sierra Nevada (cf. Rantz, 1969), although the highest elevation regions of the Fort Sage and Virginia Mountains may receive precipitation amounts comparable to the Sierra Nevada.

Craig (1961) showed that the $\delta^{18} \mathrm{O}$ and $\delta \mathrm{D}$ values of precipitation samples from around the world are linearly correlated and are best represented by the equation

$$
\delta \mathrm{D}=8 \delta^{18} \mathrm{O}+10
$$

known as the global meteoric water line (GMWL). In detail, both the slope of this line and its y-intercept, also called the deuterium excess (or $d$-value), vary with geographic location such that different regions will often have slightly different "local" meteoric water lines (LMWL). Significant deviations of the LMWL from the GMWL usually indicate the influence of various physical processes, such as evaporation. Determining the extent of these effects is important when comparing the isotopic compositions of groundwaters and meteoric waters for a particular region. For example, if a groundwater shows a significant shift from the GMWL, it is important to be able to quantify how much of this shift is due to deviations of the LMWL from the GMWL.

Sixteen precipitation samples were collected in the Honey Lake basin between June, 1995 and August, 1996. Considerable variation exists in the stable isotopic compositions of different storm events (see Table 3), with ${ }^{18} \mathrm{O}$ values ranging from -4.4 to $-22.8 \%$ and $\delta \mathrm{D}$ values ranging from -36 to $-171 \%$. Most of this variability is related to the origin and trajectory of a particular storm event. Storms that originate from polar regions have much lower $\delta^{18} \mathrm{O}$ and $\delta \mathrm{D}$ values than storms originating from subtropical areas. The weighted average for all Honey Lake precipitation (rain + snow) is $\delta^{18} \mathrm{O}=-13.5$ and $\delta \mathrm{D}=-104$. 
However, the water content of the snow samples were not measured directly, and this estimate is based on an assumed snowpack density of $25 \%$. The non-weighted precipitation average (rain + snow) is $\delta^{18} \mathrm{O}=-14.0$ and $\delta \mathrm{D}=-109$.

A linear regression through the Honey Lake precipitation data yields a LMWL with the equation

$$
\delta \mathrm{D}=7.55 \delta^{18} \mathrm{O}-3.00
$$

represented by the solid line in Figure 3. The GMWL of Craig (1961) is shown as a dashed line for comparison. Relative to the GMWL, the Honey Lake Basin LMWL has a slightly lower slope and a significantly lower $d$-value. These features are common in low-humidity, arid environments (e.g., Ehhalt et al., 1963; Benson and Klieforth, 1989; Ingraham et al., 1991; Friedman et al., 1992; Benson, 1994) and are attributable to the evaporation of raindrops falling through unsaturated air (Friedman et al., 1962; Stewart, 1975; Gat, 1980). The evaporation process enriches a raindrop in the heavy isotopes, shifting its $\delta^{18} \mathrm{O}$ and $\delta \mathrm{D}$ values to the right of the GMWL (Craig et al., 1963). In the case of storm systems moving eastward from the Sierra Nevada, the dramatic change in topography along the western margin of Honey Lake valley suddenly increases the cloud-to-ground travel distance of a raindrop by several thousand feet. Depending on the radius of the water droplet and the atmospheric relative humidity, this increase in travel distance can result in a substantial amount of evaporation.

Snowfall normally provides a more accurate measure of the isotopic composition of a cloud because snow does not evaporate as it falls through the atmosphere. For example, in a precipitation study conducted in southern Nevada, Benson and Klieforth (1989) observed that rainfall events typically plotted along an evaporation-shifted LMWL, whereas snowfall events defined a regression line almost identical to the GMWL.

Two of the snow samples collected during this study plot very close to the GMWL in Figure 3, but five other samples plot directly on the LMWL. Most of the snow samples were collected at relatively low elevations, where snowfall seldom lasts throughout the 
winter. It is therefore noteworthy that the samples that plot close to the GMWL (sample \# 073 and 074 , Table 3 ) were collected immediately following a snowfall event, whereas those that plot on the LMWL sat on the ground for nearly two weeks prior to sampling. Recrystallization and partial melting within a snowpack can cause an isotopic enrichment similar to the evaporation effect in raindrops (Friedman et al., 1991; Sommerfeld et al., 1991). This process may explain the isotopic enrichments observed in some snow samples collected during this study.

Stone et al. (1990) measured the stable isotope compositions of three snow cores collected at high elevations in the Fort Sage and Virginia Mountains during the winter of 1990. They observed a range in $\delta^{18} \mathrm{O}$ values from -17.8 to $-21.2 \%$, with corresponding $\delta \mathrm{D}$ values between -129 and $-155 \%$. All of their samples plot along the GMWL.

\subsection{2 $\delta^{18} O$ and $\delta D$ in Surface Waters}

The seasonal infiltration of mountain snowmelt carried by streams and rivers is another important component of groundwater recharge. Fifteen different streams and rivers were sampled, primarily during spring runoff, and analyzed for their $\delta^{18} \mathrm{O}$ and $\delta \mathrm{D}$ values. In addition, standing bodies of water were sampled (including Honey Lake) to evaluate evaporation effects. Sample locations are shown in Figure 4, and analytical results are given in Table 2.

The $\delta^{18} \mathrm{O}-\delta \mathrm{D}$ pairs for streams originating in the Sierra Nevada, including the Diamond Mountains, generally plot close to the GMWL (circles in Figure 5). The Sierra Nevada receives the heaviest precipitation in the region, mostly as winter snowfall. These data suggest that high elevation Sierran snowfall is similar in composition to the GMWL. In contrast, surface runoff from other parts of the basin generally plots along the LMWL (diamonds in Figure 5), reflecting evaporation effects during precipitation, or evaporation of runoff prior to infiltration. 
The Susan River and its tributary, Willow Creek, together make up approximately $60 \%$ of the total annual runoff in the basin, and are the principal source of water in Honey Lake (Rockwell, 1990). The Susan River originates at high elevations in the Sierra Nevada and adjacent Cascade Range, whereas Willow Creek originates in the Eagle Lake region. Both of these streams show enriched isotopic values compared to other waters from the same regions. However, in both cases, a significant amount of runoff is derived from intermontane lakes or reservoirs.

In general, standing bodies of water are highly susceptible to evaporation effects, as reflected by $\delta^{18} \mathrm{O}-\delta \mathrm{D}$ pairs that plot well to the right of the LMWL. The evaporation process is characterized by a kinetic isotope separation effect that concentrates the remaining liquid in the heavier isotopes (Craig et al., 1963). Evaporating bodies of water define a linear relationship between $\delta^{18} \mathrm{O}$ and $\delta \mathrm{D}$ with a slope in the range of 2 to 5.5. The slope of the evaporation line reflects the rate of vapor separation and isotopic exchange with atmospheric water vapor, and is strongly dependent on the relative humidity (Craig et al., 1963). The intercept with the meteoric water line defines the initial isotopic value of the water before evaporation started.

We conducted an experiment at the Sierra Army Depot during the summer of 1996 to determine the local slope of the evaporation line during conditions of maximum vapor loss. A standard evaporation pan that initially contained 30 gallons $(114 \mathrm{~L})$ of water was allowed to evaporate in the sun, and samples were periodically collected and analyzed for their $\delta^{18} \mathrm{O}$ and $\delta D$ values. The results are given in Figure 6 and Table 4 . The average evaporation rate integrated over the duration of the eight day experiment was $1.0 \mathrm{~cm}$ day ${ }^{-1}$ A linear regression through the isotope data gives the best-fit equation:

$$
\delta \mathrm{D}=3.9 \delta^{18} \mathrm{O}-63 .
$$

The slope of 3.9 represents the evaporation trajectory during the warm, dry summer months. It is interesting to note that a somewhat greater evaporation slope of 5.3 is 
observed for water evaporating from Honey Lake (Figure 5). The difference reflects variations in evaporation conditions at different times during the year, as well as different surface area to volume ratios for the evaporating water masses (cf. Craig et al., 1963; Gat, 1971; Ingraham and Criss, 1993).

\subsection{3 $\delta^{18} O$ and $\delta D$ in Springs}

Natural spring waters provide another useful indicator of the stable isotope composition of local groundwater recharge. Water samples were collected from 26 different springs in the Honey Lake Basin, mostly during April, 1996. The majority of the springs are located in two geographic areas: (1) the region north and northeast of Susanville, and (2) the Fort Sage-Virginia Mountains (Figure 4). The analytical results are compiled in Table 2. Variations in the $\delta^{18} O$ versus $\delta \mathrm{D}$ values of the springs are shown in Figure 7, along with order of magnitude estimates of their discharge rates (in liters per minute). The data show a good correlation between spring discharge rates and isotopic compositions.

Many of the smaller springs with discharge rates $\leq 10 \mathrm{~L} \mathrm{~min}^{-1}$ have evaporated $\delta^{18} \mathrm{O}-\delta \mathrm{D}$ pairs that plot to the right of the LMWL (Figure 7). In a few cases, the spring orifice was inaccessibly located beneath an open, evaporating pool. However, most samples were collected directly from the discharge point, which typically consisted of a pipe driven horizontally into the ground. Under these circumstances, enriched isotopic values are more suggestive of evaporation during recharge, or evaporative loss of shallow groundwater through the vadose zone (Barnes and Allison, 1983; Allison et al., 1983).

Springs with higher discharge rates $\left(>10 \mathrm{~L} \mathrm{~min}^{-1}\right)$ typically have lower $\delta^{18} \mathrm{O}$ and $\delta \mathrm{D}$ values that plot along the LMWL. All but one of the springs with flow rates $>10 \mathrm{~L} \mathrm{~min}^{-1}$ have $\delta^{18} \mathrm{O}$ values <-14\%o (Figure 7). The largest perennial springs represent the integrated flow of a large aquifer wherein heterogeneities in the isotopic values of individual recharge events are averaged out during subsurface mixing (e.g. Wenner et al., 1991). In contrast, 
small desert springs can exhibit large fluctuations in both discharge and $\delta^{18} \mathrm{O}$ in response to heavy recharge events (e.g. Ingraham et al., 1991).

\subsection{4 $\delta^{18} O$ and $\delta D$ in Groundwater}

Groundwater samples were collected from more than 60 wells in Honey Lake Valley (Figure 8), including a detailed set of samples from the Sierra Army Depot (SIAD) in Herlong (Figure 9). Isotopic and chemical data are given in Table 1. The majority of the wells penetrate shallow, unconsolidated alluvial aquifers, and have perforation intervals less than 250 feet $(76 \mathrm{~m})$. Fewer than $10 \%$ of the wells that were sampled extend to depths greater than 500 feet $(152 \mathrm{~m})$.

The groundwater stable isotope data is presented on two different graphs showing $\delta^{18} \mathrm{O}$ versus $\delta \mathrm{D}$ (Figure 10), and $\delta^{18} \mathrm{O}$ as a function of depth (Figure 11). On each graph, the data is separated into five groups, representing samples from the following locations: (1) the SIAD and other nearby wells (circles); (2) the region northwest of Honey Lake (boxes); (3) the Long Valley region (diamonds); (4) the Fish Springs Ranch area (triangles); and (5) geothermal wells (crosses).

The majority of groundwater samples have $\delta^{18} \mathrm{O}$ values between -13 and $-15 \%$, and $\delta \mathrm{D}$ values between -100 and $-120 \%$ (Figure 10). It is notable that many of the groundwaters are shifted to the right of the LMWL, indicating evaporation beyond that which occurred during precipitation. As a group, the samples from the SIAD show this evaporation effect most clearly. Many of the SIAD samples are from shallow monitoring wells located near the central axis of the basin, where the water table is sufficiently shallow to permit direct evaporative loss through the unsaturated zone (e.g., Barnes and Allison, 1983; Allison et al., 1983). Small amounts of evaporated surface water may also infiltrate this region. However, the widespread occurrence of evaporated groundwaters near the center of the basin is good evidence that this is predominantly a groundwater discharge area. 
In contrast, samples from the area northwest of Honey Lake (the second largest data group) conform reasonably well to the LMWL (Figure 10). The northwestern basin is characterized by higher precipitation rates relative to the SIAD, and closer proximity to important recharge areas. A similar argument can be made for the Long Valley data, although one of the Long Valley samples (sample \# 030) is relatively evaporated.

The Fish Springs Ranch and geothermal samples show relatively depleted isotopic signatures with $\delta^{18} \mathrm{O}$ values in the range of $-15 \%$. In the case of the Fish Springs samples, this may be related to recharge from the northern Virginia Mountains, where non-evaporated spring waters exhibit $\delta^{18} \mathrm{O}$ values in the range of -14.5 to $-15.1 \%$ o (cf. Bohm, 1990; Webber, 1996). In contrast, the geothermal samples represent deep groundwaters that are moderately shifted to the right of the LMWL (Figure 10). Geothermal waters commonly exhibit a positive ${ }^{18} \mathrm{O}$-shift due to fluid-rock isotopic exchange at elevated temperatures (Craig, 1963). Groundwater $\delta D$ values remain essentially constant during this process. If we restore these samples to their pre-shifted values on the LMWL, we find that the recharge waters would have $\delta^{18} \mathrm{O}$ values as low as $-15.8 \%$. If we project back to the GMWL, the unshifted values would drop as low as $-16.5 \%$. These values are lower than any modem recharge in the Honey Lake region. We will later show that these deeper waters represent old groundwater that was recharged during the last glacial period.

The variation in $\delta^{18} \mathrm{O}$ as a function of depth is shown in Figure 11. Whenever possible, the sample depth is represented as the center of the well perforation interval. When these data were unavailable, total well depth was used instead. Perforation intervals are known for approximately $80 \%$ of the wells that were sampled (see Table 1). At shallow depths, the groundwaters show a wide variation in $\delta^{18} \mathrm{O}$ values, ranging from about -8.5 to $-15.2 \%$. The highest $\delta^{18} \mathrm{O}$ values occur at depths $<100$ feet, and represent highly evaporated groundwater (see Figure 11). With increasing depth, the range of values becomes more restricted, although a variation of $>1$ permil persists to depths of around 500 feet. Below 
500 feet, only three samples are available, but the range in $\delta^{18} \mathrm{O}$ values is tightly grouped around $-15 \%$.

Detailed depth profiles are available for two sets of cluster piezometers located on the SIAD in Herlong. Each piezometer cluster includes four separate boreholes that represent discrete production intervals for nearby potable supply wells (PSW \#5 and PSW \#8). The locations of these wells are shown in Figure 9. Significant differences are observed in the $\delta^{18} \mathrm{O}$-depth profiles of the two piezometer clusters (Figure 12), even though they are located only a mile apart. Although the $\delta^{18} \mathrm{O}$ values for both piezometer clusters are similar at a depth of $\sim 200$ feet, PSW \#5 shows a $\delta^{18} \mathrm{O}$ range of only 0.3 permil over its entire depth profile (-13.6 to $-13.9 \%$ ) whereas PSW \#8 steadily decreases in $\delta^{18} \mathrm{O}$ with depth, ranging from -13.8 to $-15.1 \%$. These differences imply the presence of entirely different groundwater masses within relatively short lateral distances. The ${ }^{14} \mathrm{C}$ and noble gas data for these same wells reinforce this interpretation (see Figure 18 and discussion below).

The PSW \#5 and PSW \#8 piezometer data strongly suggest the presence of an impermeable groundwater divide at depths greater than about 250 feet in the Herlong area. It is notable that a linear projection of the Warm Springs fault trace off the north side of the Fort Sage Mountains exactly bisects the PSW \#5 and \#8 wells (Figure 13). Faults are known to be impermeable barriers to lateral groundwater flow in some cases. It should be emphasized that this structural boundary has important implications for groundwater flow patterns in the basin. If the Warm Springs fault zone forms a continuous barrier to flow across the entire southwestern side of the basin, it suggests that recharge from the Sierra Nevada will not reach the eastern half of the basin. This implies that virtually all modern groundwater recharge to the east of Honey Lake probably originates in the eastern Fort Sage, Virginia and Skedaddle Mountains. We cannot rule out the possibility of additional recharge from the north, flowing beneath Honey Lake. However, major fault systems also occur to the north of Honey Lake, including the Antelope Mountain fault zone (Figure 1), which may represent a northern continuation of the Warm Springs fault system. 


\subsection{Radiocarbon Dating of Groundwaters}

Carbon-14 is a naturally occurring radioactive isotope with a half life of 5730 years that is widely used to date carbon-bearing materials with ages less than about 40,000 years. One common application of ${ }^{14} \mathrm{C}$ dating is the measurement of dissolved inorganic carbon (DIC) in groundwaters to determine aquifer residence times (Mook, 1980; Fontes, 1992). DIC in groundwater originates from two main sources: (1) the biogenic production of $\mathrm{CO}_{2}$ in the soil zone, either from plant root respiration or from the decomposition of organic matter, and (2) the chemical dissolution of carbonate minerals (Fontes, 1983). The latter process can significantly dilute the ${ }^{14} \mathrm{C}$ content of the DIC before any radiogenic decay has taken place. Therefore, a central issue in the interpretation of ${ }^{14} \mathrm{C}$ data involves estimating how much of the observed DIC is derived from "active" ${ }^{14} \mathrm{CO}_{2}$ in the soil zone, and to what extent this initial ${ }^{14} \mathrm{C}$ content has been modified by reactions with carbonate minerals.

A common method of evaluating the relative proportions of different carbon sources involves using stable carbon isotope ratios $\left({ }^{13} \mathrm{C}^{12} \mathrm{C}\right)$, which are reported using the standard $\delta$-notation. Biogenic soil $\mathrm{CO}_{2}$ gas ranges in $\delta^{13} \mathrm{C}$ from -12 to $-25 \%$, depending on the type of vegetation. Marine carbonate rocks do not occur in the Honey Lake Basin, but carbonate mineralization does occur in the form of fresh water carbonate precipitates and tufa deposits. Benson et al. (1996) measured the carbon isotope compositions for a number of tufa samples collected in the Lake Lahontan basin (a Pleistocene lake that covered an area including the Honey Lake and Pyramid Lake basins). The tufas have $\delta^{13} \mathrm{C}$ values ranging from -0.2 to $+5.7 \%$. Sedimentary carbonate minerals precipitated directly from lake waters are expected to show the same range of compositions.

A number of models have been developed using $\delta^{13} \mathrm{C}$ data to correct for modifications of the initial ${ }^{14} \mathrm{C}$ activity in DIC by chemical dilution and isotopic exchange processes (e.g. Pearson and Hanshaw, 1970; Deines et al., 1974; Wigley, 1975; Mook, 1976; Fontes and Garnier, 1979). Unfortunately, these models are best applied to relatively simple hydrologic systems where dispersion and mixing effects are minimal. Available data 
indicates that groundwater mixing is a significant process in the Honey Lake aquifer (see discussion below). It is nevertheless possible to use ${ }^{14} \mathrm{C}$ data to gain insight into relative age differences without making absolute age determinations. Moreover, simple models for estimating ages can be developed by assuming the initial ${ }^{14} \mathrm{C}$ activities of all samples experienced a uniform amount of chemical reaction (e.g. Vogel, 1970).

\subsection{1 $\delta^{13} \mathrm{C}$ and ${ }^{14} \mathrm{C}$ Variations in Honey Lake Basin Groundwaters}

Radiocarbon values were measured for 35 groundwater samples and one surface water from Honey Lake. The samples ranged from 112 to $10 \mathrm{pmc}$, yielding uncorrected ages ranging from modem to 19,000 years (Table 1). Radiocarbon values greater than 100 pmc indicate young waters containing ${ }^{14} \mathrm{C}$ derived from the atmospheric testing of nuclear weapons (Levin et al., 1980). The $\delta^{13} \mathrm{C}$ values were determined for 42 groundwaters and 10 surface waters or springs, which ranged in composition from -14.4 to $+0.4 \%$.

The variation in ${ }^{14} \mathrm{C}$ with $\delta^{18} \mathrm{O}$ is shown in Figure 15. The data are divided into the same geographic groups that were shown in Figures 10 and 11 . The youngest groundwaters, with ${ }^{14} \mathrm{C}$ ages $\leq 4000$ years, generally have $\delta^{18} \mathrm{O}$ values $>-14 \%$. Note there are two independent trends toward decreasing $\delta^{18} \mathrm{O}$ values with increasing ${ }^{14} \mathrm{C}$ age, indicated by arrows. Both trends project toward $\delta^{18} \mathrm{O}$ values in the range of $-15 \%$, but the ${ }^{14} \mathrm{C}$ ages of the two groups are significantly different. The $10 w_{-1}{ }^{18} \mathrm{O}$ group with the younger ages ( $\leq 8200$ years) includes all of the Fish Springs Ranch samples, and a shallow groundwater from west of Shaffer Mountain (sample \#9) that was discussed earlier. These samples are interpreted to represent relatively recent recharge of low $\delta^{18} \mathrm{O}$ water that resides at shallower levels ( $\leq 300$ feet) in the basin.

A second trend in Figure 15 projects toward samples with older ${ }^{14} \mathrm{C}$ ages up to 19,000 years. These include the geothermal well samples, the PSW \#8 piezometer samples, and groundwaters from deep wells or locations near the center of the basin. This group is interpreted to represent deeper groundwater, some of which is ascending under hydraulic 
pressure to shallower levels in the SIAD region. The depleted $\delta^{18} \mathrm{O}$ values and old ${ }^{14} \mathrm{C}$ ages of the deepest samples suggest they were recharged during cooler climatic conditions that existed at the time Lake Lahontan covered this area. Lake Lahontan achieved a high stand in this region between 14,000 and 12,500 years ago (Benson and Mifflin, 1986; Benson et al., 1990).

Figure 16 is a plot of $\delta^{13} \mathrm{C}$ versus ${ }^{14} \mathrm{C}$ values for Honey Lake Basin groundwaters. The plot also includes a single data point from Honey Lake. Although there is considerable scatter in the data, it is nevertheless possible to draw some general conclusions regarding the sources of DIC in these waters. The entire range in groundwater $\delta^{13} \mathrm{C}$ values (from about -2 to $-14 \%$ ) is observed in samples with ${ }^{14} \mathrm{C}$ ages less than about 5000 years. With increasing age, the range in $\delta^{13} \mathrm{C}$ becomes narrower, such that samples with ${ }^{14} \mathrm{C}$ ages $>10,000$ years all have $\delta^{13} \mathrm{C}$ values in the range of -10 to $-14 \%$.

Recall that biogenic soil $\mathrm{CO}_{2}$ gas ranges in $\delta^{13} \mathrm{C}$ from -12 to $-25 \%$. During the conversion of $\mathrm{CO}_{2}$ gas to dissolved bicarbonate, an isotopic fractionation occurs that enriches the dissolved carbon in ${ }^{13} \mathrm{C}$ by approximately $9 \%$ relative to the $\mathrm{CO}_{2}$ gas (Mook et a1., 1974). Therefore, biogenic $\mathrm{CO}_{2}$ gas with $\delta^{13} \mathrm{C}$ values in the range of -19 to $-23 \%$ o would readily account for the large number of groundwater samples with $\delta^{13} \mathrm{C}$ values in the -10 to $-14 \%$ range. This source largely accounts for the $\delta^{13} \mathrm{C}$ compositions observed in the oldest groundwater samples, with little indication of extensive carbonate dissolution or exchange reactions. This suggests that the ${ }^{14} \mathrm{C}$ ages observed in the oldest, deepest samples mostly result from radioactive decay, not dilution effects such as water-rock interaction. Caution is still required in interpreting these ${ }^{24} \mathrm{C}$ values as "true" ages since groundwater mixing effects can significantly influence the observed values. However, if mixing did occur, one of the mixing components would need to be older than the observed ${ }^{14} \mathrm{C}$ values.

Referring again to Figure 16 , the relatively high $\delta^{13} \mathrm{C}$ values in some of the groundwater samples suggests (1) closed system reactions with soil zone carbonate minerals (calcite) during groundwater recharge; and/or (2) mixing with a ${ }^{13} \mathrm{C}$-enriched groundwater that 
underwent equilibration with atmospheric $\mathrm{CO}_{2}$ gas. In the first case, up to $50 \%$ of the DIC in groundwater can be derived from soil carbonate (Mook, 1980), and this can account for up to one half-life of ${ }^{14} \mathrm{C}$ apparent aging $(\sim 5700$ years). Assuming an average carbonate mineral $\delta^{13} \mathrm{C}$ value of $+3 \%$, reaction of biogenic $\mathrm{CO}_{2}$ gas with soil carbonate can enrich the resultant DIC by 12 to $13 \%$ relative to the biogenic $\mathrm{CO}_{2}$. This results in a $\delta^{13} \mathrm{C}$ value of -8 to $-10 \%$ for the groundwater DIC. However, this process cannot account for all of the observed ${ }^{13} \mathrm{C}$ enrichment.

An alternative explanation for some of the heavy $\delta^{13} \mathrm{C}$ values involves direct equilibration with atmospheric $\mathrm{CO}_{2}$ gas. Modern atmospheric $\mathrm{CO}_{2}$ has a $\delta^{13} \mathrm{C}$ value of approximately $-8 \%$ (Keeling et al., 1989). Dissolved bicarbonate in isotopic equilibrium with atmospheric $\mathrm{CO}_{2}$ gas will therefore have a $\delta^{13} \mathrm{C}$ value around $+1 \%$. Partial isotopic equilibration will yield somewhat lower $\delta^{13} \mathrm{C}$ values. This mechanism provides a plausible explanation for the isotopic composition of Honey Lake surface water $\left(\delta^{13} \mathrm{C}=-2.6 \%\right.$ ), which has a ${ }^{14} \mathrm{C}$ value of $104 \mathrm{pmc}$. It would also explain the relatively high $\delta^{13} \mathrm{C}$ values observed in many of the creek and river samples $\left(\delta^{13} \mathrm{C}=-0.3\right.$ to $-6.5 \%$; Table 2). Mixing of regional groundwater with this atmospherically-equilibrated groundwater may explain some of the high $\delta^{13} \mathrm{C}$ values observed in Figure 16.

The variation in ${ }^{14} \mathrm{C}$ age as a function of depth is shown in Figure 17. Whenever possible, the sample depth is represented by the average well perforation interval. In all other cases ( $<15 \%$ of the data), total well depths were plotted. A majority of the data lie along a concave downward mixing curve. Groundwaters from depths less than 200 feet show a wide range in ${ }^{14} \mathrm{C}$ ages (up to 12,000 years) that are interpreted to reflect shallow mixing of young groundwater with older waters ascending under hydraulic pressure. Alternatively, older groundwater rising into discharge areas may simply undergo partial reequilibration of its dissolved inorganic carbon with modem biogenic or atmospheric $\mathrm{CO}_{2}$ gas. Long term fluctuations of the water table would help facilitate this process. 
At depths greater than 200 feet, the ${ }^{14} \mathrm{C}$ data can be separated into two groups depending on whether the data conform to the mixing curve. All groundwater samples with ${ }^{14} \mathrm{C}$ ages $>12,000$ years occur at depths $>300$ feet and plot along the steeply dipping part of the mixing curve. These data include groundwaters from the deepest parts of the basin that were previously interpreted to represent Pleistocene waters recharged during Lake Lahontan time. The concave down form of this curve is similar to the age profiles predicted during numerical simulations of discharge from a regional aquifer system undergoing advectivedispersive transport (e.g. Goode, 1996).

A second group of samples with ${ }^{14} \mathrm{C}$ ages less than 8,500 years occur at depths between 200 and 500 feet, including all four of the PSW \#5 piezometer samples. These data plot below the mixing curve in Figure 17. Two of the samples are quite young ( 2500 years), providing evidence for the deep transmission of relatively recent recharge. It is notable that all of the samples in this group occur in close proximity to fault zones. This implies that under some circumstances, faults may provide a mechanism for the rapid vertical transport of groundwater. These data also reinforce the concept that faults create barriers to lateral groundwater transport. With one exception, all of the samples that fall off the mixing trend in Figure 17 are from wells located to the west of the Warm Springs fault zone. This fault system appears to play a significant role in separating older waters in the eastern part of the basin from younger waters to the west.

Comparison of the ${ }^{14} \mathrm{C}$ age versus depth profiles from the PSW \#5 and PSW \#8 piezometer clusters strengthens this argument (Figure 18). Recall from our previous discussion that the $\delta^{18} \mathrm{O}$-depth profiles in the PSW \#5 and \#8 piezometer groups showed the presence of isotopically distinct groundwater masses on either side of the Warm Springs fault (Figure 12). The data in Figure 18 reveals a large difference in the ${ }^{14} \mathrm{C}$ ages of groundwaters from these two piezometer groups. The PSW \#5 samples (west of the fault) have ${ }^{14} \mathrm{C}$ ages ranging from 2800 to 7900 years with the youngest groundwater occurring at a depth of $\sim 300$ feet. In contrast, the PSW \#8 samples (east of the fault) show a systematic 
increase in age with depth, ranging from 12,000 to 16,800 years. The lateral distance between these two well clusters is $\sim 2 \mathrm{~km}$. Groundwaters from two other deep wells in this area (PSW \#2 and \#9) show similar ${ }^{14} \mathrm{C}$ age relationships relative to the Warm Springs fault zone (see Figure 13).

\subsection{Tritium Measurements}

Tritium $\left({ }^{3} \mathrm{H}\right)$ is a radioactive isotope of hydrogen that undergoes decay to ${ }^{3} \mathrm{He}$ with a half-life of 12.3 years. Although there is a small rate of natural production of tritium in the atmosphere, most tritium in the environment was generated during the atmospheric testing of thermonuclear weapons during the 1950's and early 1960's. This bomb-generated tritium serves as a useful tracer for detecting the presence of young recharge in groundwaters. The concentration of tritium in water is expressed as the ratio of ${ }^{3} \mathrm{H}$ atoms to ${ }^{1} \mathrm{H}$ atoms, where the ratio ${ }^{3} \mathrm{H} /{ }^{1} \mathrm{H}=10^{-18}$ is defined as 1 tritium unit (TU). Because tritium has a short half life, groundwaters with low tritium values $(<0.5 \mathrm{TU})$ are considered to have been recharged prior to 1952 .

Tritium concentrations were measured for 9 groundwaters and 2 surface runoff samples during this study (see Table 5). Groundwater tritium concentrations varied from 0 to 4.7 TU. Only two groundwater samples have tritium concentrations above the $0.5 \mathrm{TU}$ detection limit. Both of these samples (sample \#25 and \#30) were collected in the Long Valley recharge area. Interestingly, one of these samples (\#30) was among the group of young ${ }^{14} \mathrm{C}$ groundwaters that plotted below the mixing curve in Figure 17. This sample is from a well with a perforation interval of 250-350 feet that is situated along a major fault. The presence of post-1952 groundwater in this relatively deep well suggests the rapid vertical infiltration of recharge along the fault plane. Nevertheless, the majority of the groundwater samples that were analyzed for tritium during this study contained concentrations below the detection limit. This suggests a general lack of young groundwater ages in the basin. 
The two river samples that were analyzed for tritium had concentrations of 5.7 and 9.2 TU. These are consistent with the range of values expected for modern precipitation. Stone et al. (1990) measured the tritium concentrations of snow samples from the Fort Sage and Virginia Mountains during a single season and observed values ranging from 3.1 to $5.3 \mathrm{TU}$.

\subsection{Noble Gas Measurements}

Helium, neon, argon, krypton, and xenon are chemically inert gases that occur naturally in the atmosphere. The solubility of these "noble" gases in water is dependent on temperature, and is proportional to atmospheric pressure. Thus, the abundance of dissolved noble gases in a groundwater provides a means of estimating the recharge temperature of that water (e.g. Mazor, 1972; Andrews and Lee, 1979; Stute et al., 1992, 1995). The temperature that is recorded represents the mean temperature at the transition to saturated conditions. Seasonal temperature variations tend to be smoothed out during transport through the unsaturated zone. The uncertainty in the temperature calculation is typically $<1^{\circ} \mathrm{C}$ provided the recharge altitude is known to within $\sim 200 \mathrm{~m}$ ( $650 \mathrm{ft}$ ). However, prior to calculating a temperature, corrections must be applied to the data to account for the entrainment of gas bubbles during groundwater infiltration ("excess air"), and for the subsurface production of ${ }^{4} \mathrm{He}$ and ${ }^{40} \mathrm{Ar}$. This subject is reviewed by Pearson et al. (1991) and Hudson (1994).

Noble gas concentrations were measured for two groundwater samples collected from deep wells on either side of the Warm Springs fault zone. These wells (PSW \#2 and \#9) are located within the SIAD in Herlong, in close proximity to the PSW \#5 and \#8 wells that were discussed earlier (see Figure 13). The analytical results are given in Table 6. Assuming a recharge altitude of $1200 \mathrm{~m}$ (3940 ft) for both samples, the noble gas recharge temperatures were determined to be $10.4^{\circ} \mathrm{C}$ for PSW \#2 and $13.3^{\circ} \mathrm{C}$ for PSW \#9.

The relatively warm recharge temperature in PSW \#9 is associated with younger groundwaters $\left({ }^{14} \mathrm{C}\right.$ ages $<8000$ years) from the west side of the Warm Springs fault. This 
is consistent with groundwater recharge during the warmer climatic conditions of postglacial time. In contrast, the cooler recharge temperature in PSW \#2 is associated with older groundwaters $\left({ }^{14} \mathrm{C}\right.$ ages of 12,000 to 16,800 years) on the east side of the fault. The ${ }^{14} \mathrm{C}$ ages and $\delta^{18} \mathrm{O}$ values of these waters indicate recharge during colder climatic conditions that occurred during the last glacial period (e.g. Dansgaard et al., 1993; Broecker, 1994).

\section{Discussion}

\subsection{Sources of Groundwater Recharge}

Before going on to discuss groundwater recharge rates, it is useful to summarize our understanding of where groundwater recharge occurs in the Honey Lake Basin, and what impact it has on the availability of water in the region. On the basis of known precipitation rates, it is logical to assume that recharge rates should be greatest along the base of the Sierra Nevada. Although this is probably true, the amount of water that actually infiltrates the aquifer may be considerably less than was inferred by previous studies.

Figure 14 shows a summary plot of the samples that were analyzed for $\delta^{18} \mathrm{O}$ and $\delta \mathrm{D}$ during this study. The data are divided into three groups: groundwater, surface water and springs. Note that most of the surface water data (represented by boxes) plots well above the main cluster of groundwater and spring water data. Moreover, the surface water data that is the furthest removed from the main cluster of data is the Sierra Nevada runoff (circled data in Figure 14). This observation is rather remarkable since it implies that the Sierran runoff is very poorly represented in the groundwater isotopic data!

The lack of correlation between the Sierran runoff and the groundwater samples cannot be explained by evaporation processes. Mixing of an isotopically light groundwater (perhaps from a deep source) with Sierran runoff could produce an intermediate composition similar to some of the groundwater samples. However, this mechanism will not account for a majority of the groundwater data. Therefore, we are forced to conclude that modern Sierra Nevada runoff is not a major source of groundwater recharge in most of 
Honey Lake Basin. This is consistent with the concept that fault zones have created barriers to groundwater flow between the eastem and western parts of the basin. Some recharge from the Sierra Nevada undoubtedly occurs in the coarse alluvium at the base of the mountain front, particularly in the Susanville and Long Valley areas. However, the lack of a well-defined Sierran isotopic signature in most of the groundwater samples suggests a large component of the seasonal snowmelt runs off into Honey Lake, where it is lost to evaporation. The ${ }^{14} \mathrm{C}$ data presented below shows that groundwaters along the Sierran front have ages as great as 8,000 years. This further suggests that recharge rates are rather low in this area.

Available data suggests that the area northwest of Honey Lake (east of Susanville) receives some of its recharge from groundwater flowing in from further north. Nonevaporated spring waters from north of latitude $40^{\circ} 30^{\prime} \mathrm{N}$ have $\delta^{18} \mathrm{O}$ values in the range of -14.5 to $-15.2 \%$. These values are consistent with the range in $\delta^{18} \mathrm{O}$ values observed in wells west of Shaffer Mountain, including one groundwater (sample \#9; $\delta^{18} \mathrm{O}=-14.9 \%$ ) that was collected from a depth of less than 60 feet. There are no local recharge sources with such depleted $\delta^{18} \mathrm{O}$ values in this area.

As previously discussed, modern groundwater recharge to the east of Honey Lake Basin is probably limited to precipitation and runoff derived from the Fort Sage, Virginia and Skedaddle Mountains. Stable isotope data from springs and creeks in these mountains are consistent with the compositions of shallow groundwaters near Fish Springs Ranch and south of the Skedaddle Mountains (cf. Bohm, 1990; Webber, 1996). However, net recharge rates are probably fairly low in these areas. Rockwell (1990) estimated that

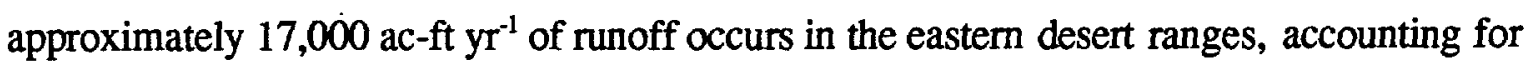
only about $7 \%$ of all runoff in the basin. Although additional recharge will occur via direct infiltration of precipitation, this is only likely to be important in high elevation areas. The extent to which high elevation infiltration contributes recharge to the alluvial aquifer depends 
on the interconnectivity of the fracture network in the volcanic and granitic rocks that comprise these ranges.

\subsection{Groundwater Recharge Rates}

Groundwater recharge rates in the Honey Lake Basin can be estimated from groundwater ${ }^{14} \mathrm{C}$ data. The approach is relatively simple, and involves calculating linear flow velocities (in $\mathrm{ft}^{\mathrm{yr}}{ }^{-1}$ ) by dividing the ${ }^{14} \mathrm{C}$ ages into the distance between the recharge point and sampling point. An average linear flow velocity is then integrated over the recharge area to obtain a flux in $\mathrm{ft}^{3} \mathrm{yr}^{-1}$. This value is readily converted to recharge units of ac-ft $\mathrm{yr}^{-1}$. Linear flow rates can be calculated for both vertical and lateral transport. For vertical transport, the distance is simply the length between the ground surface and the average perforation depth. For lateral transport, a maximum distance is calculated from the length between the sampling point and the edge of the basin where recharge was assumed to occur. The result provides a maximum estimate of the lateral flow velocity.

Average linear flow rates for the vertical infiltration of groundwater were calculated for two different cases: (1) using all the wells where ${ }^{14} \mathrm{C}$ values were measured; and (2) using only those wells that are located in recharge areas. The latter case essentially eliminates most of the SIAD wells. The calculated linear flow rates are given in Table 7, with averages given at the bottom of the table. Only the sample numbers marked with asterisks were used during the second set of calculations.

Each set of vertical flow rate calculations were performed assuming two possible ${ }^{14} \mathrm{C}$ initial values. One calculation uses uncorrected ${ }^{14} \mathrm{C}$ ages, assuming an initial ${ }^{14} \mathrm{C}$ activity ( $\mathrm{A}_{\mathrm{o}}$ ) of $100 \mathrm{pmc}$. The second calculation assumes an initial ${ }^{14} \mathrm{C}$ activity of $85 \mathrm{pmc}$, taking into account the possibility of chemical dilution effects (see Table 7).

Consider the first case, where we use all of the wells where ${ }^{14} \mathrm{C}$ values were measured. The average vertical flux of groundwater into the basin is obtained by integrating the average linear flow velocity over entire area of the basin $\left(2200 \mathrm{mi}^{2}\right)$. In all of our calculations, we 
will assume a porosity of $30 \%$. For $A_{o}=100 \mathrm{pmc}$, the average linear flow velocity is 0.04

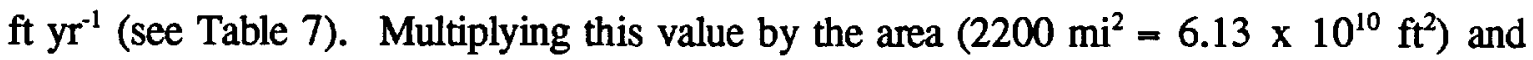
porosity (0.3), we obtain a vertical flux of $7.71 \times 10^{8} \mathrm{ft}^{3} \mathrm{yr}^{-1}$, which is equivalent to a recharge rate of $17,700 \mathrm{ac}-\mathrm{ft} \mathrm{yr}^{-1}$. For $\mathrm{A}_{\mathrm{o}}=85 \mathrm{pmc}$, the average linear flow velocity is 0.11 $\mathrm{ft} \mathrm{yr}^{-1}$, yielding a vertical flux of $1.97 \times 10^{9} \mathrm{ft}^{3} \mathrm{yr}^{-1}$, for a recharge rate of $45,300 \mathrm{ac}-\mathrm{ft}_{\mathrm{yr}}{ }^{-1}$. This range of values is considerably less than a previous recharge estimate of 130,000 ac- $\mathrm{ft}$ $\mathrm{yr}^{-1}$ given in Handman et al. (1990).

Next we will consider the case where the vertical flux is determined using only the data from wells located in assumed recharge areas. The sample data subset used for these calculations is marked with asterisks in Table 7. The assumed recharge area and porosity are the same as in the previous set of calculations. For $A_{\circ}=100$ pmc, the average linear flow velocity is again $0.04 \mathrm{ft} \mathrm{yr}^{-1}$, giving a vertical flux of $7.68 \times 10^{8} \mathrm{ft}^{3} \mathrm{yr}^{-1}$, and a recharge rate of $17,600 \mathrm{ac}-\mathrm{ft}_{\mathrm{yr}} \mathrm{r}^{-1}$. This is remarkably similar to the previous calculation using all of the groundwater ${ }^{14} \mathrm{C}$ data. For $\mathrm{A}_{\mathrm{o}}=85 \mathrm{pmc}$, the average linear flow velocity is $0.14 \mathrm{ft} \mathrm{yr}^{-1}$, yielding a vertical flux of $2.66 \times 10^{9} \mathrm{ft}^{3} \mathrm{yr}^{-1}$, and a somewhat higher recharge rate of 61,000 ac-ft $\mathrm{yr}^{-1}$.

Lateral flow velocity calculations are more problematic since we know that the Honey Lake Basin is dissected by faults that limit the interaction of groundwater between different parts of the basin. However, there are a sufficient number of wells on the west side of the Warm Springs and Antelope Mountain fault zones to make an estimate of lateral flow velocities for groundwater recharging from the Sierra Nevada range. Theoretically, this area should have the highest recharge rates due to the fact that it is the wettest part of the basin. Lateral flow rates were calculated for a total of 11 wells (including four from the PSW \#5 piezometer cluster), and are presented in Table 8. The horizontal distances were estimated from topographic maps, and represent the approximate distance from the well to the nearest bedrock exposure at the edge of the basin. Since the horizontal distance is large compared 
to the well depth, the "true" linear distance between the recharge point and the well intake is approximately the same as the measured surface distance.

Note that the horizontal flow velocities (Table 8) are approximately two orders of magnitude greater than the vertical flow velocities (Table 7). Horizontal permeabilities in sedimentary material commonly exceed vertical permeabilities by 1-2 orders of magnitude due to the geometry of alluvial deposits and the horizontal layering of sediments with contrasting permeabilities (Domenico and Schwartz, 1990). This in general validates the usefulness of the ${ }^{14} \mathrm{C}$ measurements.

Two sets of horizontal flow velocities were calculated in Table 8, assuming initial ${ }^{14} \mathrm{C}$ activities of either $100 \mathrm{pmc}$ or $85 \mathrm{pmc}$. To determine the groundwater flux, we will assume that recharge occurs along the base of the Sierra Nevada range between Susanville and the Long Valley area (near Doyle) -- a linear distance of 225,000 feet (42.6 miles). The sedimentary basin fill west of the Warm Springs and Antelope Mountain fault zones form a wedge shaped deposit with a maximum thickness of approximately 3500 feet. To obtain an average flux through this wedge, we will assume lateral transport through a vertical plane oriented parallel to the recharge area. Assuming an average depth equal to one half of the maximum depth, the area of this vertical plane is $225,000 \mathrm{ft}$. $\times 1750 \mathrm{ft} .=3.94 \times 10^{8} \mathrm{ft}^{2}$. Multiplying this area by the average horizontal flow velocity and the porosity gives us the lateral flux.

For $A_{o}=100 \mathrm{pmc}$, we calculate a lateral flux of $7.50 \times 10^{8} \mathrm{ft}^{3} \mathrm{yr}^{-1}$, which is equivalent to a recharge rate of $17,200 \mathrm{ac}-\mathrm{ft} \mathrm{yr}^{-1}$. This is very similar to the value obtained for the vertical flux for the entire basin. For $A_{\circ}=85 \mathrm{pmc}$, we calculate a lateral flux of $2.44 \times 10^{9}$ $\mathrm{ft}^{3} \mathrm{yr}^{-1}$, which gives a recharge rate of 56,200 ac-ft $\mathrm{yr}^{-1}$. However, it is notable that the $\mathrm{A}_{\circ}=$ 85 pmc data is biased toward a higher average flow velocity by a few samples with young ${ }^{14} \mathrm{C}$ model ages (Table 8). If we omit the two youngest samples from these data (sample \# 029 and 126), we obtain a flux estimate of $1.00 \times 10^{9} \mathrm{ft}^{3} \mathrm{yr}^{-1}$, equivalent to $23,100 \mathrm{ac}-\mathrm{ft}^{\mathrm{yr}}{ }^{-1}$ of recharge. This is probably a more reasonable estimate of the lateral recharge rate. It 
should be emphasized that the lateral flux calculations yield maximum recharge rate estimates based on linear flow paths. They do not take into account the curvature of the groundwater flow paths or the influence of groundwater mixing.

To summarize, the recharge rates estimated from ${ }^{14} \mathrm{C}$ data indicate a range of values from

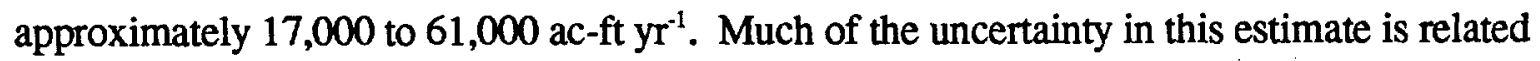
to uncertainties in the initial ${ }^{14} \mathrm{C}$ activity $\left(\mathrm{A}_{\mathrm{o}}\right.$ ) of the groundwater during recharge. Assuming a ${ }^{14} \mathrm{C}$ initial value of $85 \mathrm{pmc}$, lateral recharge rates along the base of the Sierra Nevada are in the range of 17,000 to $23,000 \mathrm{ac}-\mathrm{ft}_{\mathrm{yr}^{-1}}$, whereas the vertical recharge rates averaged over the entire basin are in the range of 45,000 to $60,000 \mathrm{ac}-\mathrm{ft}^{-1}$. This range in values is less than half of that previously estimated by Handman et al. (1990).

\section{Conclusions}

Water resources in the Honey Lake Basin were characterized using environmental isotope hydrology methods as a means of addressing current resource development issues. The stable isotopes of oxygen and hydrogen were used to identify the principal recharge areas in the basin. Recharge from relatively high winter snowfall amounts in the Sierra Nevada is limited to the westernmost part of the basin. Even in this area, the isotopic signatures of many of the groundwaters collected during this study do not match that of springtime runoff from the Sierra. This suggest that a significant fraction of the potential recharge in this area does not infiltrate the aquifer, but instead runs off into Honey Lake where it is lost to evaporation. Modern recharge water containing tritium was observed in only two wells in the Long Valley area.

In the eastern half of the basin, the stable isotope data shows that a limited amount of recharge is provided by the seasonal influx of snowmelt from the Fort Sage, Virginia, and Skedaddle Mountains. However, the low precipitation rates in this area suggest very low recharge rates. Groundwater ${ }^{14} \mathrm{C}$ ages reveal that the bulk of the groundwater east of Honey Lake was recharged during the last glacial period. Intensive groundwater pumping in the 
eastern part of the basin will draw heavily on these old groundwaters. Sustained pumping is associated with a high risk of mobilizing groundwater contaminants that currently reside in shallow groundwaters beneath the Sierra Army Depot.

The Warm Springs fault zone creates an impermeable barrier to lateral groundwater flow that separates older groundwater in the eastem basin from younger groundwater to the west. Radiocarbon ages in excess of 16,000 years were observed in groundwaters from deep wells on the east side of this fault. West of the fault, the maximum ${ }^{14} \mathrm{C}$ ages are less than 8,000 years. Noble gas recharge temperature calculations and $\delta^{18} O$ measurements of deep groundwater east of the fault are consistent with the hypothesis that recharge occurred during colder climatic conditions that existed in the area during the last ice age. At depths $<200 \mathrm{ft}$, groundwaters east of the Warm Springs fault show a range in ${ }^{14} \mathrm{C}$ ages from 2400 to 12,000 years that reflect shallow mixing of young water with older groundwater ascending under hydraulic pressure. These data reinforce earlier interpretations of this area as a groundwater discharge zone (e.g. Handman et al., 1990). The extent to which faults limit lateral groundwater transmission in the region north of Honey Lake is less clear. However, the Antelope Mountain fault zone (Figure 1) may represent a northern extension of the Warm Springs fault system.

Our best estimate of the recharge rates based on groundwater ${ }^{14} \mathrm{C}$ data gives a range of values between 45,000 and $60,000 \mathrm{ac}-\mathrm{ft}^{\mathrm{yr}^{-1}}$ for the entire basin. Estimated recharge rates along the base of the Sierra Nevada range from 17,000 to $23,000 \mathrm{ac}-\mathrm{ft}_{\mathrm{rr}} \mathrm{r}^{-1}$. These estimates are significantly lower than previous estimates given by Handman et al. (1990). 


\section{Acknowledgments}

We thank the staff at the Environmental Division of the Sierra Army Depot, in particular Robert Weis, for their support of this project. We also thank Bob Criss, Jordan Clark and

Glen Pearson for their contributions to the ideas presented in this paper. Dave Hart provided helpful advice regarding the average water content of snowpacks. 


\section{References}

Allison, G.B., Barnes, C.J. and Hughes, M.W. (1983) The distribution of deuterium and ${ }^{18} \mathrm{O}$ in dry soils. 2. Experimental. Jour. Hydrol., 64: 377-397.

Andrews, J.N. and Lee, D.J. (1979) Inert gases in groundwater from the Bunter Sandstone of England as indicators of age and paleoclimatic trends. Jour. Hydrol., 41: 233-252.

Barnes, C.J. and Allison, G.B. (1983) The distribution of deuterium and ${ }^{18} \mathrm{O}$ in dry soils. 1. Theory. Jour. Hydrol., 60: 141-156.

Benson, L.V. (1994) Stable isotopes of oxygen and hydrogen in the Truckee River Pyramid Lake surface water system. 1. Data analysis and extraction of paleoclimatic information. Limnol. Oceanogr., 39: 344-355.

Benson, L. and Klieforth, H. (1989) Stable isotopes in precipitation and ground water in the Yucca Mountain region, southern Nevada: Paleoclimatic implications. In: D.H. Peterson, ed., Aspects of Climate Variability in the Pacific and Western Americas. Amer. Geophys. Union, Geophys. Monograph 55, 41-59.

Benson, L.V. and Mifflin, M.D. (1986) Reconnaissance bathymetry of basins occupied by Pleistocene Lake Lahontan, Nevada and California. U.S. Geol. Survey WaterResources Investigations Report 85-4262, 14 p.

Benson, L.V., Currey, D.R., Dorn, R.I., Lajoie, K.R., Oviatt, C.G., Robinson, S.W., Smith, G.I. and Stine, S. (1990) Chronology of expansion and contraction of four Great Basin lake systems during the past 35,000 years. Palaeogeogr. Palaeoclimatol. Palaeoecol., 78: 241-286.

Benson, L.V., White, L.D. and Rye, R. (1996) Carbonate deposition, Pyramid Lake Subbasin, Nevada: 4. Comparison of the stable isotope values of carbonate deposits (tufas) and the Lahontan lake-level record. Palaeogeogr. Palaeoclimatol. Palaeoecol., 122: 45-76.

Bohm, B. (1990) Isotope hydrology of southern Honey Lake Valley, Nevada and California. Unpublished report, Washoe County Utility Division, Reno, Nevada. $62 \mathrm{p}$. 
Bonham, H.F. (1969) Geology and mineral deposits of Washoe and Storey Counties, Nevada. Nevada Bureau of Mines Bulletin 70, 140 p.

Broecker, W.S. (1994) Massive iceberg discharges as triggers for global climate change. Nature, 372: 421-424.

Coleman, M.L., Sheperd, T.J., Durham, J.J., Rouse, J.E. and Moore, G.R. (1982) Reduction of water with zinc for hydrogen isotope analysis. Anal. Chem., 54: 993-995.

Craig, H. (1961) Isotopic variations in meteoric waters. Science, 133: 1702-1703.

Craig, H. (1963) The isotopic geochemistry of water and carbon in geothermal areas. In: E. Tongiorgi, ed., Nuclear Geology on Geothermal Areas. Consiglio Nazionale delle Ricerche, Laboratorio di Geologia Nucleare, Pisa, Italy, pp. 17-53.

Craig, H., Gordon, L.I. and Horibe, Y. (1963) Isotope exchange effects in the evaporation of water. 1. Low-temperature experimental results. Jour. Geophys. Res., 68: 5079-5087.

Criss, R.E. (1994) Stable isotope distribution: Variations from temperature, organic and water-rock interactions. In: Handbook of Physical Constants, Sec. 1-20. Am. Geophys. Union, 14 p.

Dansgaard, W. (1964) Stable isotopes in precipitation. Tellus, 16: 436-468.

Dansgaard, W., Johnsen, S.J., Clausen, H.B., Dahl-Jensen, D., Gundestrup, N.S., Hammer, C.U., Hvidberg, C.S., Steffensen, J.P., Sveinbjornsdottir, A.E., Jouzel, J. and Bond, G. (1993) Evidence for general instability of past climate from a 250-kyr ice-core record. Nature, 364: 218-220.

Deines, P., Langmuir, D. and Harmon, R.S. (1974) Stable carbon isotope ratios and the existence of a gas phase in the evolution of carbonate groundwaters. Geochim. Cosmochim. Acta, 38: 1147-1164.

Domenico, P.A. and Schwartz, F.W. (1990) Physical and Chemical Hydrogeology. John Wiley and Sons, New York, 824 p.

Drever, J.I. (1982) The Geochemistry of Natural Waters. Prentice-Hall, Englewood Cliffs, New Jersey, 388 p. 
Ehhalt, D., Knott, K., Nagel, J.F. and Vogel, J.C. (1963) Deuterium and oxygen 18 in rain water. Jour. Geophys. Res., 68: 3775-3780.

Epstein, S. and Mayeda, T.K. (1953) Variation of $\mathrm{O}^{18}$ content of waters from natural sources. Geochim. Cosmochim. Acta, 4: 213-224.

Fontes, J.Ch. (1980) Environmental isotopes in groundwater hydrology. In: P.Fritz and J.Ch. Fontes, eds., Handbook of Environmental Isotope Geochemistry, Volume 1, The Terrestrial Environment. Elsevier, Amsterdam, pp. 75-140.

Fontes, J.Ch. (1983) Dating of groundwater. In: Guidebook on Nuclear Techniques in Hydrology. IAEA Technical Reports Series, no. 91, pp. 285-317.

Fontes, J.Ch. (1992) Chemical and isotopic constraints on ${ }^{14} \mathrm{C}$ dating of groundwater. In: R.E. Taylor, et al., eds., Radiocarbon after Four Decades: An Interdisciplinary Perspective. Springer-Verlag, New York, pp. 242-261.

Fontes, J.Ch. and Garnier, J.M. (1979) Determination of the initial ${ }^{14} \mathrm{C}$ activity of the total dissolved carbon: a review of the existing models and a new approach. Water Resour. Res., 15: 399-413.

Friedman, I., Machta, L. and Soller, R. (1962) Water-vapor exchange between a water droplet and its environment. Jour. Geophys. Res., 67: 2761-2766.

Friedman, I., Benson, C. and Gleason, J. (1991) Isotopic changes during snow metamorphism. In: H.P. Taylor, Jr., J.R. O'Neil and I.R. Kaplan, eds., Stable Isotope Geochemistry: A Tribute to Samuel Epstein. Geochem. Soc. Special Pub. 3, p. 211-221.

Friedman, I., Smith, G.I., Gleason, J.D., Warden, A. and Harris, J.M. (1992) Stable isotope composition of waters in southeastern California. 1. Modern precipitation. Jour. Geophys. Res., 97: 5795-5812.

Gat, J.R. (1971) Comments on the stable isotope method in regional groundwater investigations. Water Resour. Res., 7: 980-993.

Gat, J.R. (1980) The isotopes of hydrogen and oxygen in precipitation. In: P. Fritz and J.Ch. Fontes, eds., Handbook of Environmental Isotope Geochemistry, Volume 1, The Terrestrial Environment. Elsevier, Amsterdam, p. 21-47. 
Goode, D.J. (1996) Direct simulation of groundwater age. Water Resour. Res., 32: 289-296.

Grose, T.L.T., Saucedo, G.J. and Wagner, D.L. (1990) Geologic map of the Susanville Quadrangle, Lassen and Plumas Counties, California, scale 1:100,000. California Division of Mines and Geology, Open File Report 91-1, 26 p.

Handman, E.H., Londquist, C.J. and Maurer, D.K. (1990) Groundwater resources of Honey Lake Valley, Lassen County, California and Washoe County, Nevada. U.S. Geol. Survey Water-Resources Investigations Report 90-4050, 112 p.

Hem, J.D. (1985) Study and interpretation of the chemical characteristics of natural waters, Third Edition. U.S. Geol. Survey Water-Supply Paper 2254, 263 p.

Hudson, G.B. (1994) Natural and artificial noble gas hydrologic tracers. Lawrence Livermore National Laboratory Report UCRL-ID-117543, 30 p.

Ingraham, N.L. and Taylor, B.E. (1991) Light stable isotope systematics of large-scale hydrologic regimes in California and Nevada. Water Resour. Res., 27: 77-90.

Ingraham, N.L., Lyles, B.F., Jacobson, R.L. and Hess, J.W. (1991) Stable isotopic study of precipitation and spring discharge in southern Nevada. Jour. Hydrol., 125: 243-258.

Ingraham, N.L. and Criss, R.E. (1993) Effects of surface area and volume on the rate of isotopic exchange between water and water vapor. Jour. Geophys. Res., 98: 20,54720,553 .

Juncal, R.W. and Bohm, B. (1987) A conceptual model of the Wendel-Amedee geothermal system, Lassen County, CA. Trans. Geotherm. Resour. Council, 11: 601-606.

Keeling, C.D., Bacastow, R.B., Carter, A.F., Piper, S.C., Whorf, T.P., Heimann, M., Mook, W.G. and Roeloffzen, H. (1989) A three-dimensional model of atmospheric $\mathrm{CO}_{2}$ transport based on observed winds: 1 . Analysis of observational data. Geophys. Monograph No. 55, Am. Geophys. Union, Washington DC, pp. 165-236.

Levin, I., Munnich, K.O. and Weiss, W. (1980) The effect of anthropogenic $\mathrm{CO}_{2}$ and ${ }^{14} \mathrm{C}$ sources on the distribution of ${ }^{14} \mathrm{C}$ in the atmosphere. In: M. Stuiver and R.S. Kra, eds., Proceedings of the 10th International ${ }^{14} \mathrm{C}$ Conference. Radiocarbon, 22: 379-391. 
Mazor, E. (1972) Paleotemperatures and other hydrological parameters deduced from noble gases dissolved in groundwaters: Jordan Rift Valley, Israel. Geochim. Cosmochim. Acta, 36: 1321-1336.

Mazor, E. (1991) Applied Chemical and Isotopic Groundwater Hydrology. Open University, Buckingham, UK, 274 p.

McNichol, A.P., Jones, G.A., Hutton, D.L., Gagnon, A.R. and Key, R.M. (1994) The rapid preparation of seawater $\Sigma \mathrm{CO}_{2}$ for radiocarbon analysis at the National Ocean Sciences AMS Facility. Radiocarbon, 36: 237-246.

Mook, W.G. (1976) The dissolution-exchange model for dating groundwater with ${ }^{14} \mathrm{C}$. In: Interpretation of Environmental Isotope and Hydrochemical Data in Groundwater Hydrology. IAEA, Vienna, pp. 213-225.

Mook, W.G. (1980) Carbon-14 in hydrogeological studies. In: P.Fritz and J.Ch. Fontes, eds., Handbook of Environmental Isotope Geochemistry, Volume 1, The Terrestrial Environment. Elsevier, Amsterdam, pp. 49-74.

Mook, W.G., Bommerson, J.C. and Staverman, W.H. (1974) Carbon isotope fractionation between dissolved bicarbonate and gaseous carbon dioxide. Earth Planet. Sci. Lett., 22: 169-176.

Pearson, F.J., Jr. and Hanshaw, B.B. (1970) Sources of dissolved carbonate species in groundwater and their effects on carbon-14 dating. In: Isotope Hydrology. IAEA, Vienna, pp. 271-286.

Pearson, F.J., Jr., Balderer, W., Loosli, H.H., Lehmann, B.E., Matter, A., Peters, Tj., Schmassmann, H. and Gautschi, A. (1991) Applied Isotope Hydrogeology - A Case Study in Northern Switzerland. Studies in Environmental Science, Vol. 43. Elsevier, Amsterdam, $439 \mathrm{p}$.

Plummer, L.N. and Busenberg, E. (1982) The solubilities of calcite, aragonite and vaterite in $\mathrm{CO}_{2}-\mathrm{H}_{2} \mathrm{O}$ solutions between 0 and $90^{\circ} \mathrm{C}$, and an evaluation of the aqueous model for the system $\mathrm{CaCO}_{3}-\mathrm{CO}_{2}-\mathrm{H}_{2} \mathrm{O}$. Geochim. Cosmochim. Acta, 46: 1011-1040.

Rantz, S.E. (1969) Mean annual precipitation in the California region. U.S. Geol. Survey Basic Data Compilation, Isohyetal map, scale 1:1,000,000. 
Roberts, C.T. (1985) Cenozoic evolution of the northwestern Honey Lake Basin, Lassen County, Califomia. Colorado School of Mines Quarterly, 80 (1), 64 p.

Rockwell, G.L. (1990) Surface-water hydrology of Honey Lake Valley, Lassen County, California, and Washoe County, Nevada. U.S. Geol. Survey Open File Report $90-177,2$ sheets.

Sommerfeld, R.A., Judy, C. and Friedman, I. (1991) Isotopic changes during the formation of depth hoar in experimental snowpacks. In: H.P. Taylor, Jr., J.R. O'Neil and I.R. Kaplan, eds., Stable Isotope Geochemistry: A Tribute to Samuel Epstein. Geochem. Soc. Special Pub. 3, p. 205-209.

Stewart, J.H. (1988) Tectonics of the Walker Lane belt, western Great Basin: Mesozoic and Cenozoic deformation in a shear zone. In: Ernst, W.G., ed., Metamorphism and crustal evolution of the westem United States. Prentice-Hall, Englewood Cliffs, New Jersey, p. 681-713.

Stewart, M.K. (1975) Stable isotope fractionation due to evaporation and isotopic exchange of falling waterdrops: applications to atmospheric processes and evaporation of lakes. Jour. Geophys. Res., 80: 1133-1146.

Stone, R., Albright, W. and Adams, G. (1990) A reconnaissance survey of the chemical and isotopic composition of snow from the Honey Lake Region from the 1990 winter season. Desert Research Institute, Atmospheric Sciences Center, Reno, Nevada, 14 p.

Stuiver, M. and Polach, H. (1977) Reporting of ${ }^{14} \mathrm{C}$ data. Radiocarbon, 19: 355-363.

Stumm, W. and Morgan, J.J. (1981) Aquatic Chemistry, 2nd edition. Wiley, New York, $780 \mathrm{p}$.

Stute, M., Schlosser, P., Clark, J.F. and Broecker, W.S. (1992) Paleotemperatures in the southwestern United States derived from noble gases in ground water. Science, 256: 1000-1003.

Stute, M., Clark, J.F., Schlosser, P., Broecker, W.S. and Bonani, G. (1995) A 30,000 yr continental paleotemperature record derived from noble gases in groundwater from the San Juan Basin, New Mexico. Quaternary Research, 43: 209-220. 
Surano, K.A., Hudson, G.B., Failor, R.A., Sims, J.M., Holland, R.C., MacLean, S.C. and Garrison, J.C. (1992) Helium-3 mass spectrometry for low-level tritium analysis of environmental samples. Jour. Radioanal. Nuclear Chem. Articles, 161: 443-453.

Vogel, J.C. (1970) Carbon-14 dating of groundwater. In: Isotope Hydrology. IAEA, Vienna, pp. 225-239.

Vogel, J.S., Southen, J.R. and Nelson, D.E. (1987) Catalyst and binder effects in the use of filamentous graphite for AMS. Nuclear Instruments and Methods in Physics Research, B29: 50-56.

Walker, F.W., Parrington, J.R. and Feiner, F. (1989) Nuclides and Isotopes. General Electric Co. Nuclear Energy Operations, San Jose, California, 57 p.

Webber, W.D. (1996) Salinization of shallow ground waters in Honey Lake Valley, California-Nevada. Unpublished M.S. Thesis, Brigham Young University, Provo, Utah, 87 p.

Wenner, D.B., Ketcham, P.D. and Dowd, J.F. (1991) Stable isotopic composition of waters in a small Piedmont watershed. In: H.P. Taylor, Jr., J.R. O'Neil and I.R. Kaplan, eds., Stable Isotope Geochemistry: A Tribute to Samuel Epstein. Geochem. Soc. Special Pub. 3, pp. 195-203.

Wigley, T.M.L. (1975) Carbon 14 dating of groundwater from closed and open systems. Water Resour. Res., 11: 324-328. 


\section{Figure Captions}

Figure 1. Location map of the Honey Lake Basin showing major physiographic features and fault zones.

Figure 2. Plot of conductivity versus alkalinity values for surface waters, springs and groundwaters from the Honey Lake Basin.

Figure 3. Plot of $\delta^{18} \mathrm{O}$ versus $\delta \mathrm{D}$ values for precipitation samples. Circles represent rainwaters whereas triangles indicate snow samples. GMWL (dashed line) refers to the global meteoric water line of Craig (1961). The equation $\delta \mathrm{D}=7.55 \delta^{18} \mathrm{O}-3.00$ represents the best fit linear regression line through the data (solid line), hereafter referred to as the local meteoric water line (LMWL).

Figure 4. Location map of spring and surface water samples collected during this study. Spring locations are indicated by solid circles; triangles indicate surface water sampling locations. Numbers correspond to the sample numbers in Table 2.

Figure 5. Plot of $\delta^{18} \mathrm{O}$ versus $\delta \mathrm{D}$ values of surface waters. GMWL is the global meteoric water line (dashed line). LMWL is the local meteoric water line for Honey Lake precipitation (solid line). The evaporation line $\delta \mathrm{D}=5.3 \delta^{18} \mathrm{O}-29$ is the best fit regression line through the Sierra Nevada runoff (circles) and Honey Lake surface water samples.

Figure 6. Plot of $\delta^{18} \mathrm{O}$ versus $\delta \mathrm{D}$ values for samples collected during a pan evaporation experiment conducted in early August, 1996. The data define an evaporation equation $\delta \mathrm{D}=3.9 \delta^{18} \mathrm{O}-63$. Evaporation rates averaged approximately $1.0 \mathrm{~cm}$ day ${ }^{-1}$ during the course of the experiment.

Figure 7. Plot of $\delta^{18} \mathrm{O}$ versus $\delta \mathrm{D}$ values of spring waters. Samples are separated into groups according to estimated spring discharge rates. Note that more evaporated waters (plotting to the right of the LMWL) are generally associated with lower discharge rates.

Figure 8. Location map of groundwater samples collected from Honey Lake Valley. Numbers correspond to the sample numbers in Table 1. 
Figure 9. Location map of groundwater samples collected from the Sierra Army Depot in Herlong (inset from Figure 8). Numbers indicate sample numbers given in Table 1.

Figure 10. Plot of $\delta^{18} \mathrm{O}$ versus $\delta \mathrm{D}$ values of groundwater samples. The data is separated into five geographic groups representing samples from the Sierra Army Depot and nearby locations (circles); the region northwest of Honey Lake, including the Susanville area (squares); the Long Valley region (diamonds); the Fish Springs Ranch region (triangles); and Geothermal wells (crosses). Note that a majority of the groundwater samples are more evaporated than the local meteoric water line (LMWL).

Figure 11. Plot of groundwater $\delta^{18} \mathrm{O}$ values as a function of depth. For approximately $80 \%$ of the samples, depth is represented by the average well perforation interval. For the remaining samples, total well depth is plotted. Note that the range in $\delta^{18} \mathrm{O}$ values becomes more restricted with increasing depth, approaching values of around $-15 \%$.

Figure 12. Plot of $\delta^{18} \mathrm{O}$ versus depth relationships for the PSW \#5 (circles) and PSW \#8 (squares) piezometer clusters, located in Herlong. Although these wells are located only $\sim 2 \mathrm{~km}$ apart, the $\delta^{18} \mathrm{O}$ data indicates the presence of discrete groundwater masses at depth.

Figure 13. Map of southeastern Honey Lake Valley showing the locations of the four PSW wells sampled during this study. Ages indicate the uncorrected ${ }^{14} \mathrm{C}$ values measured for groundwater from these wells. $T_{R}$ refers to the noble gas recharge temperatures measured in PSW \#2 and \#9. The trace of the Warm Springs fault zone bisects this group of wells, and accounts for the significant difference in groundwater ${ }^{14} \mathrm{C}$ ages and recharge temperatures on either side of the fault.

Figure 14. Plot of $\delta^{18} \mathrm{O}$ versus $\delta \mathrm{D}$ values for all groundwater, surface water and spring water samples collected during this study. Note that the main cluster of surface water samples (squares) plot above the groundwater and spring water group. These surface waters were predominantly collected during springtime runoff from the Sierra Nevada. The lack of correspondence between these samples and the bulk of the groundwater data indicates that modern Sierra Nevada runoff is not a dominant source of recharge to most of the basin. 
Figure 15. Plot of $\delta^{18} \mathrm{O}$ versus ${ }^{14} \mathrm{C}$ values of groundwater samples. The data define two trends of decreasing $\delta^{18} \mathrm{O}$ with increasing ${ }^{14} \mathrm{C}$ age (arrows). The samples plotting along the upper trend represent younger recharge in areas dominated by low $\delta^{18} \mathrm{O}$ waters, as in the Fish Springs Ranch area. Samples that plot along the lower trend represent older groundwaters from the deeper parts of the basin.

Figure 16. Plot of $\delta^{13} \mathrm{C}$ versus ${ }^{14} \mathrm{C}$ values of groundwater samples. The large number of samples with $\delta^{13} \mathrm{C}$ values in the range of -10 to $-14 \%$ indicate that biogenic $\mathrm{CO}_{2}$ is a dominant source of dissolved inorganic carbon in these samples. More enriched $\delta^{13} \mathrm{C}$ values indicate (1) closed system reactions with soil zone carbonate minerals (calcite) during groundwater recharge; and/or (2) mixing with a ${ }^{13} \mathrm{C}$-enriched groundwater that underwent equilibration with atmospheric $\mathrm{CO}_{2}$ gas.

Figure 17. Plot of groundwater ${ }^{14} \mathrm{C}$ values as a function of depth. The curve indicates mixing between old, deep groundwaters ascending near the center of the basin, and younger groundwaters at shallower depths. Note that the groundwater data shows a range in ${ }^{14} \mathrm{C}$ ages from 1500 to 12,000 years at depths less than 200 feet. The majority of samples that cluster below the mixing curve represent groundwaters collected west of the Warm Springs fault zone.

Figure 18. Plot of ${ }^{14} \mathrm{C}$ age versus depth relationships for the PSW \#5 (circles) and PSW \#8 (squares) piezometer clusters, located in Herlong. The disparity in the ${ }^{14} \mathrm{C}$ ages of these two groups of samples reinforces the interpretation that the Warm Springs fault is an impermeable barrier to lateral groundwater transport. 


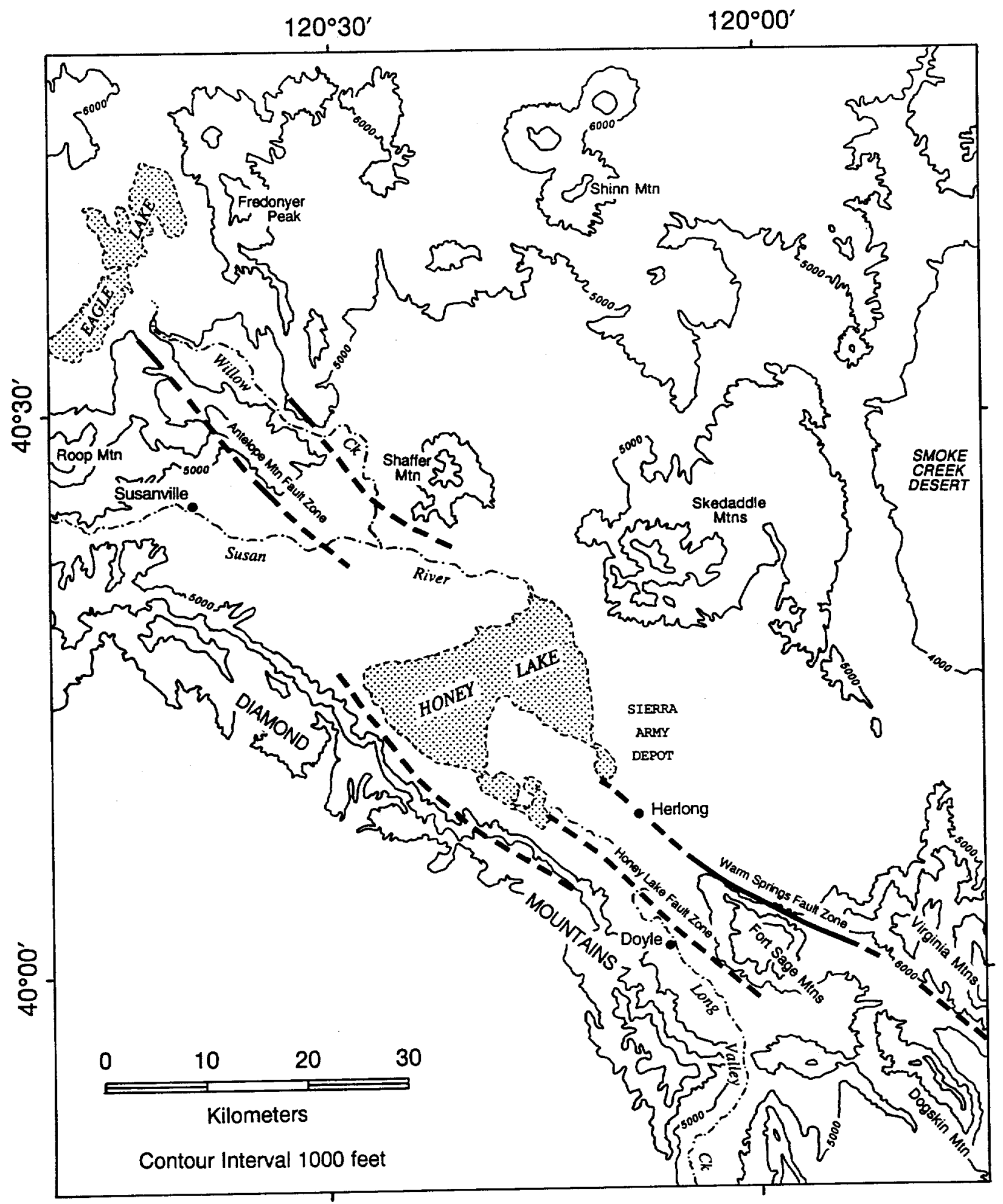

Figure 1 


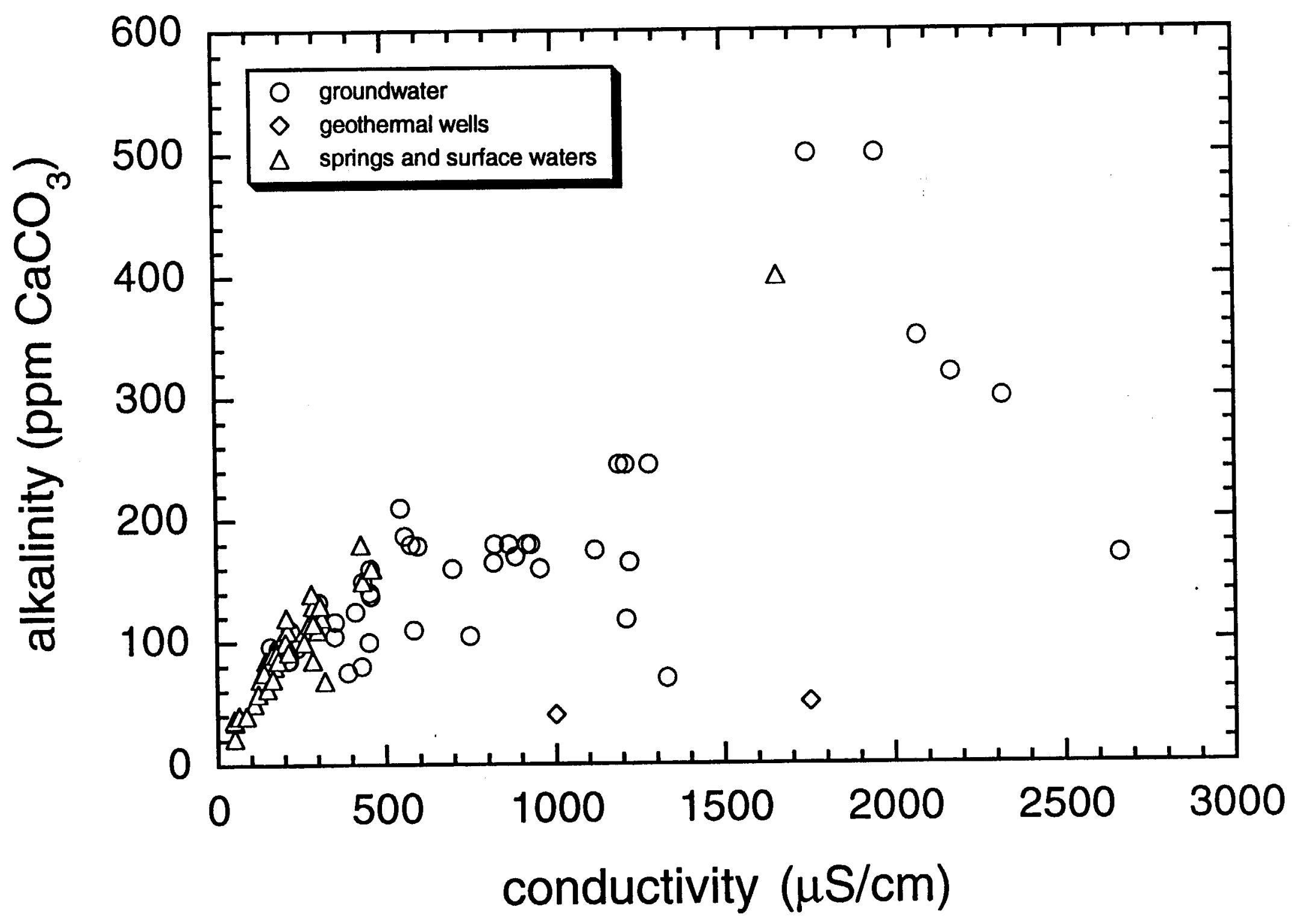




\section{Honey Lake precipitation}

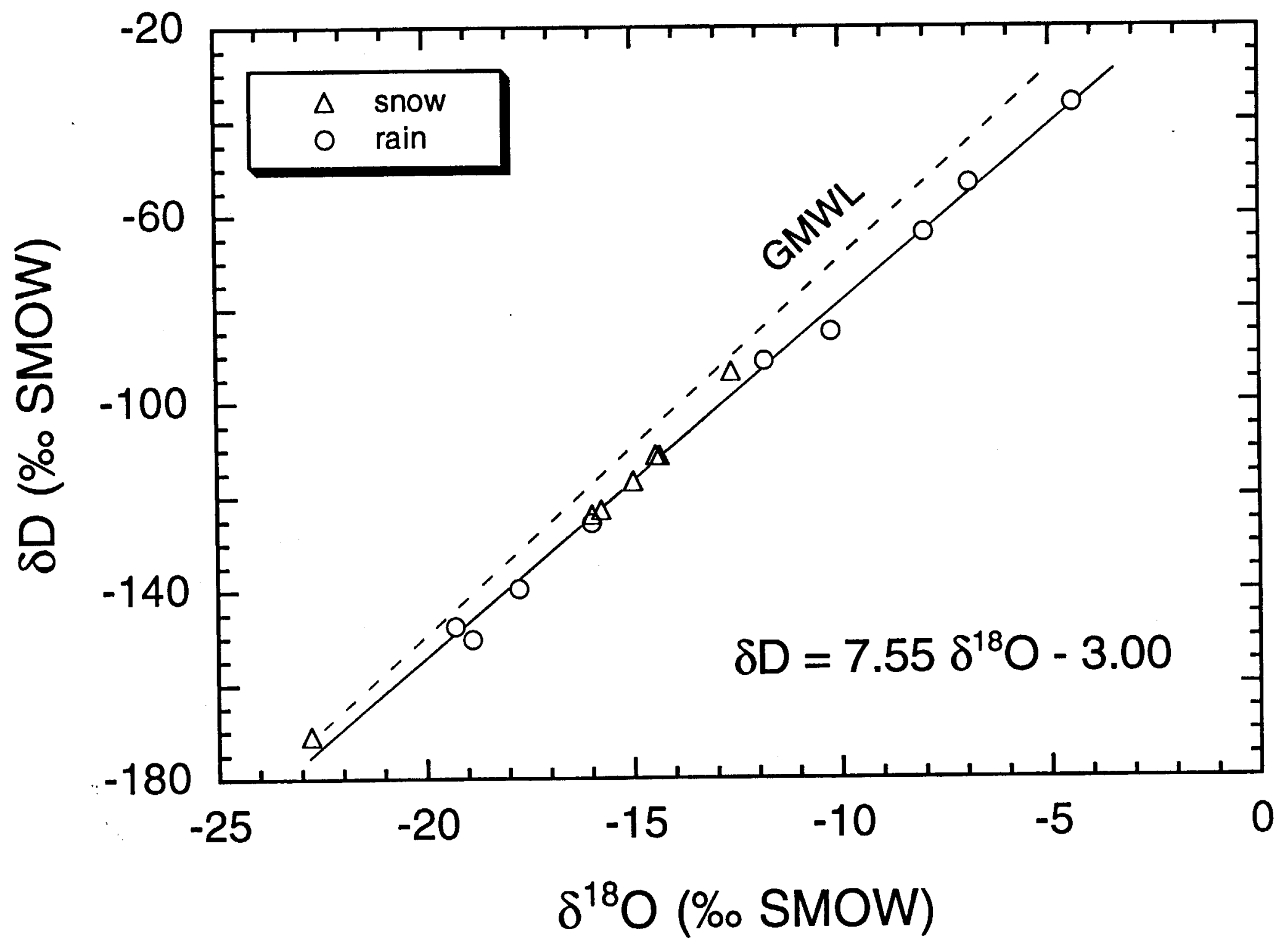




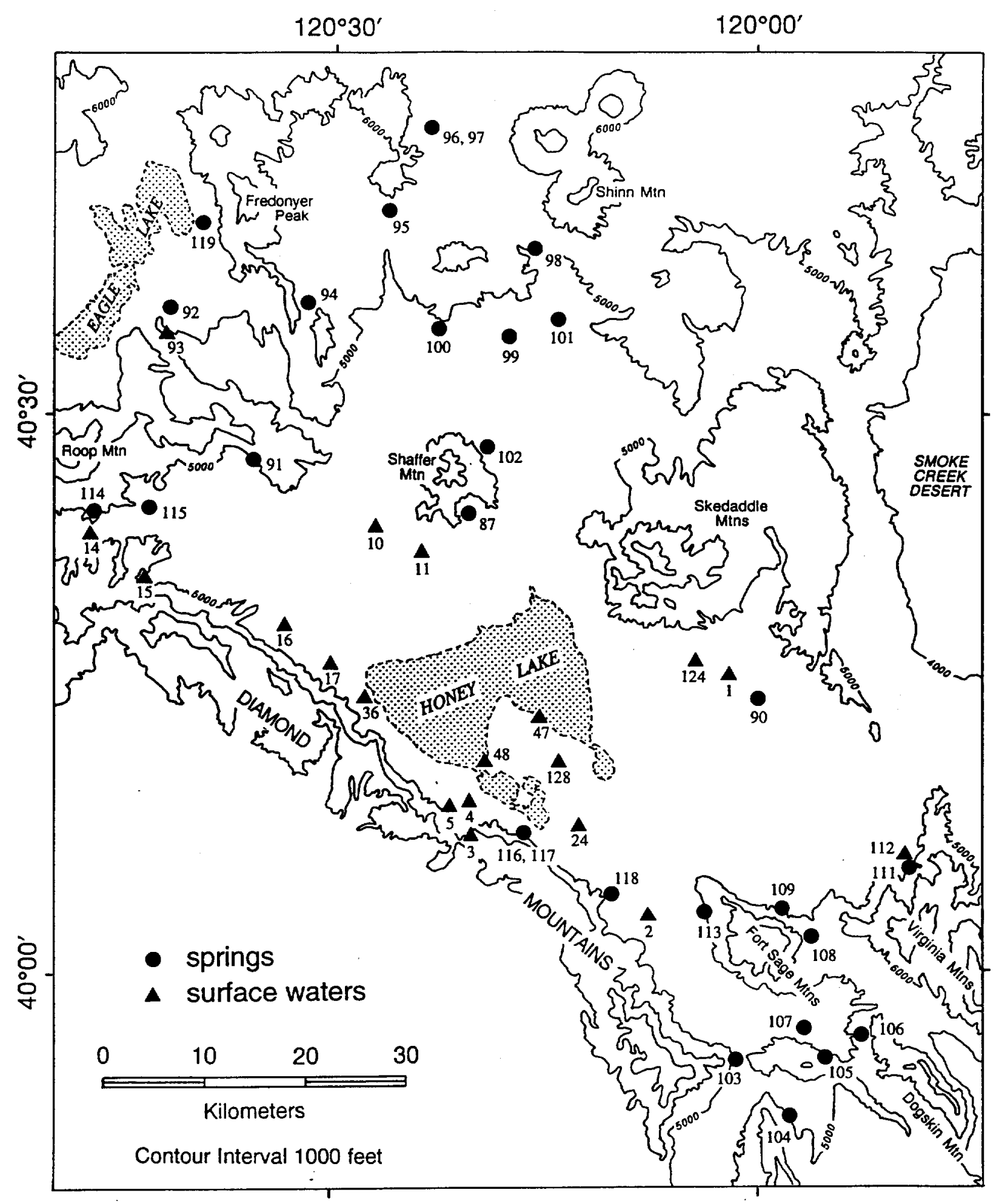

Figure 4 


\section{Honey Lake Basin surface waters}

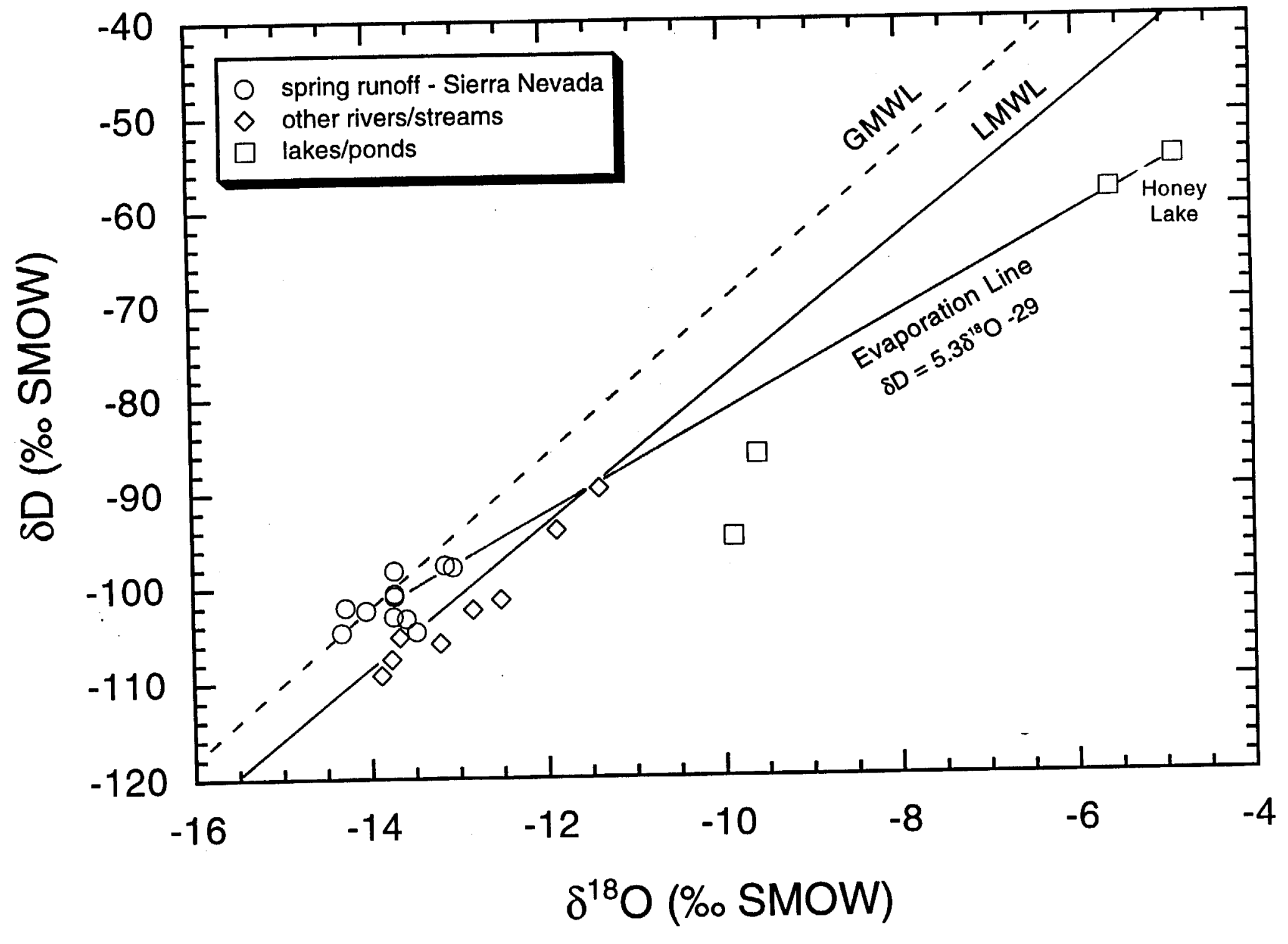




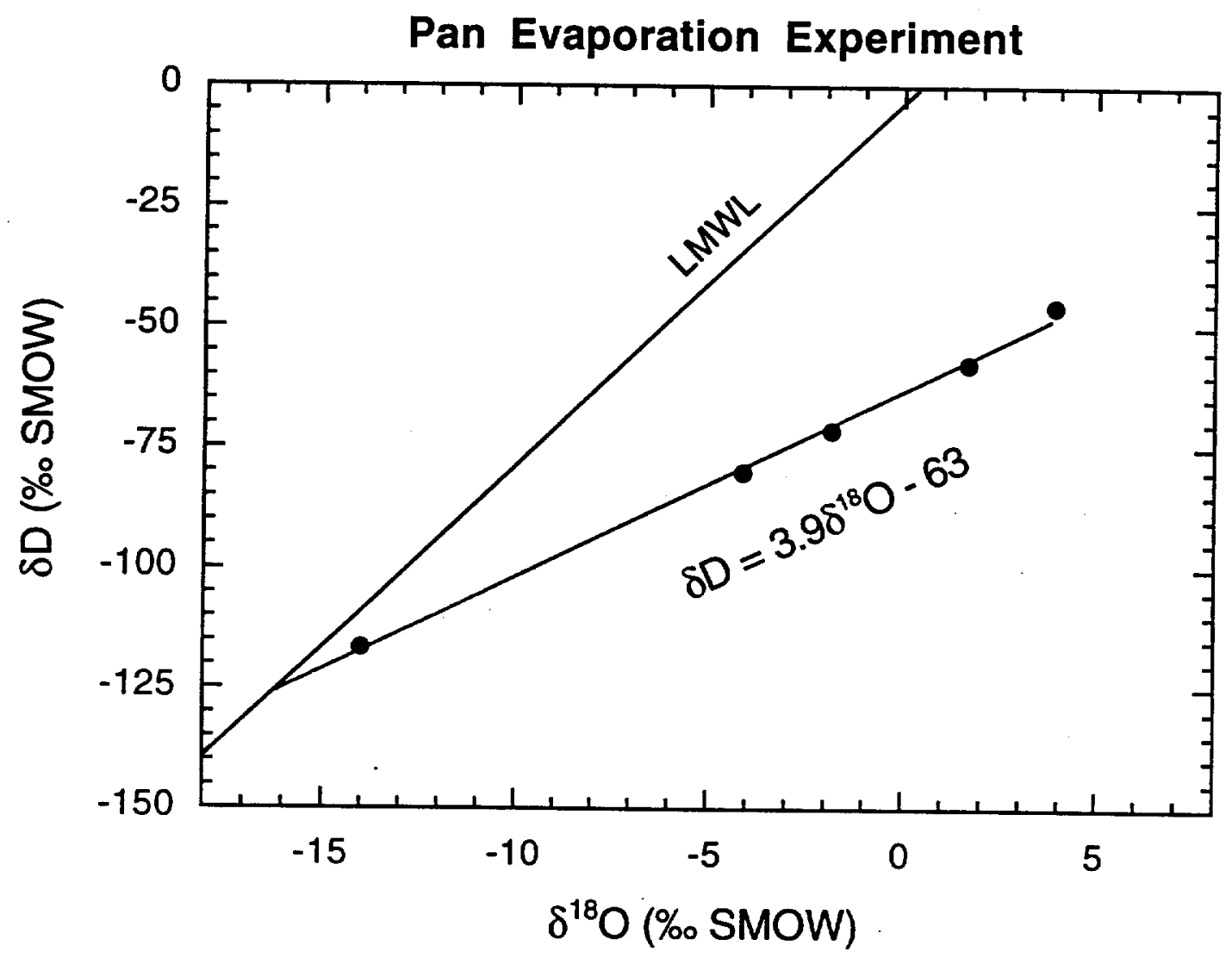

Figure 6 
Honey Lake Basin Spring Waters

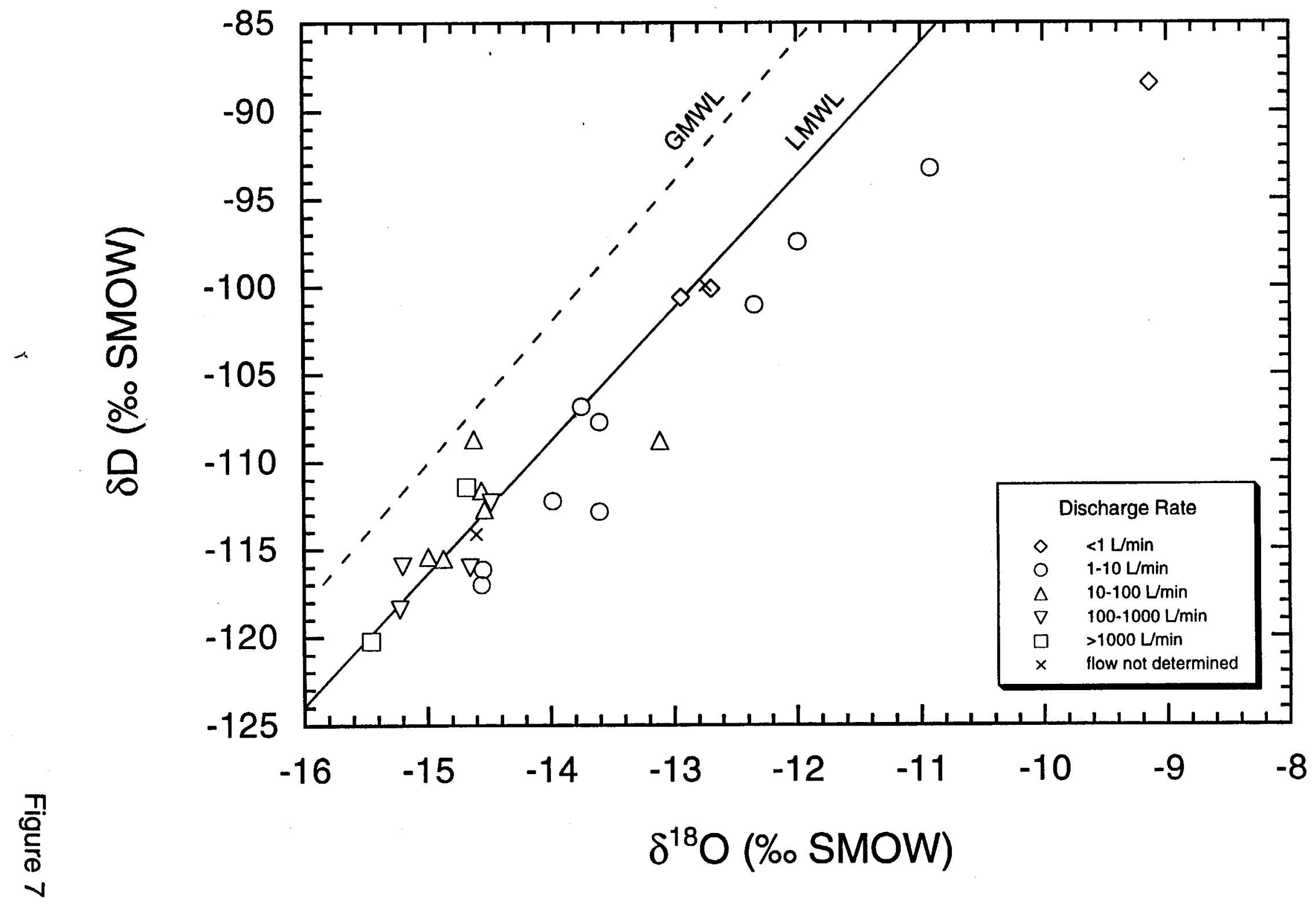




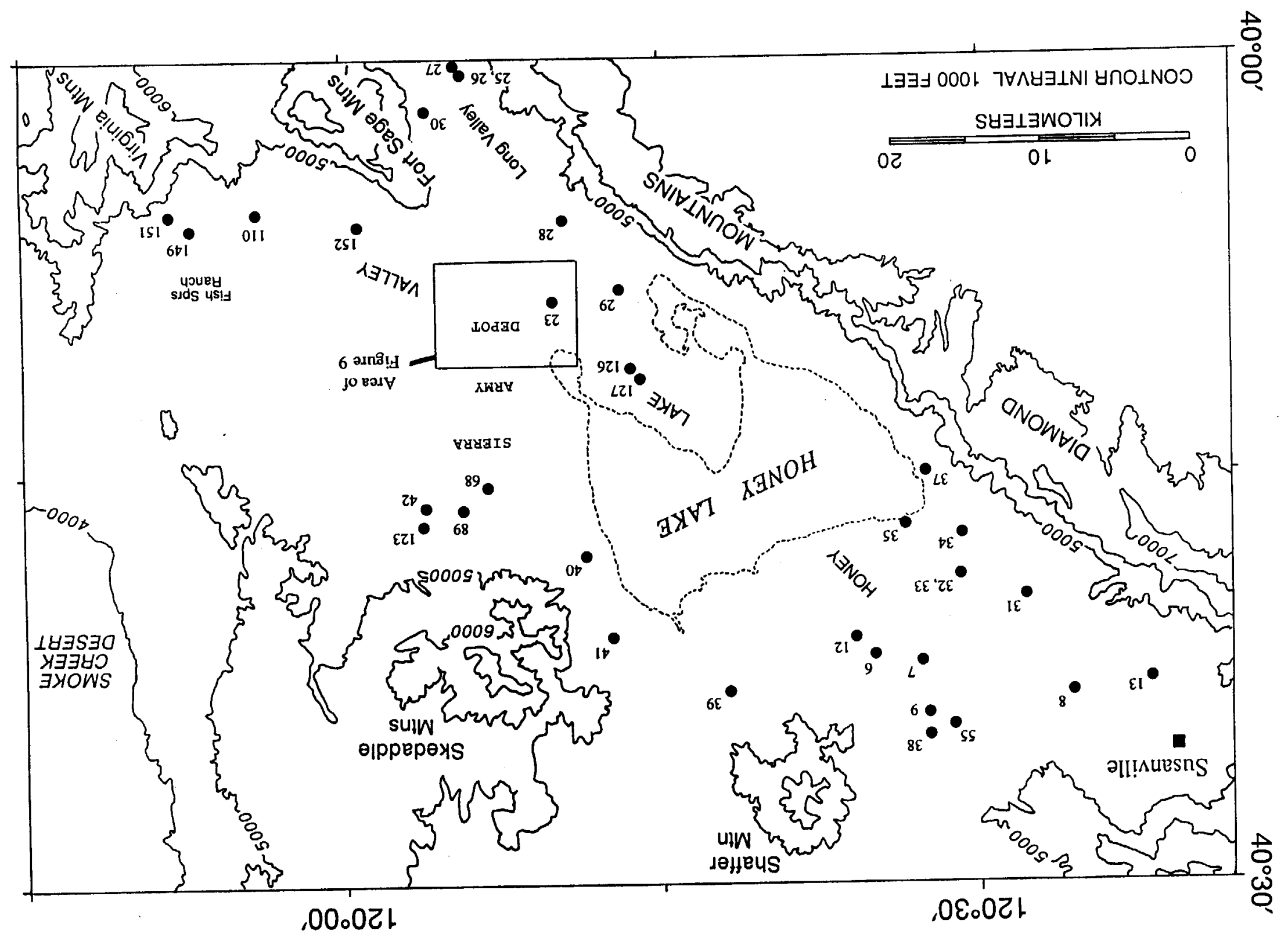




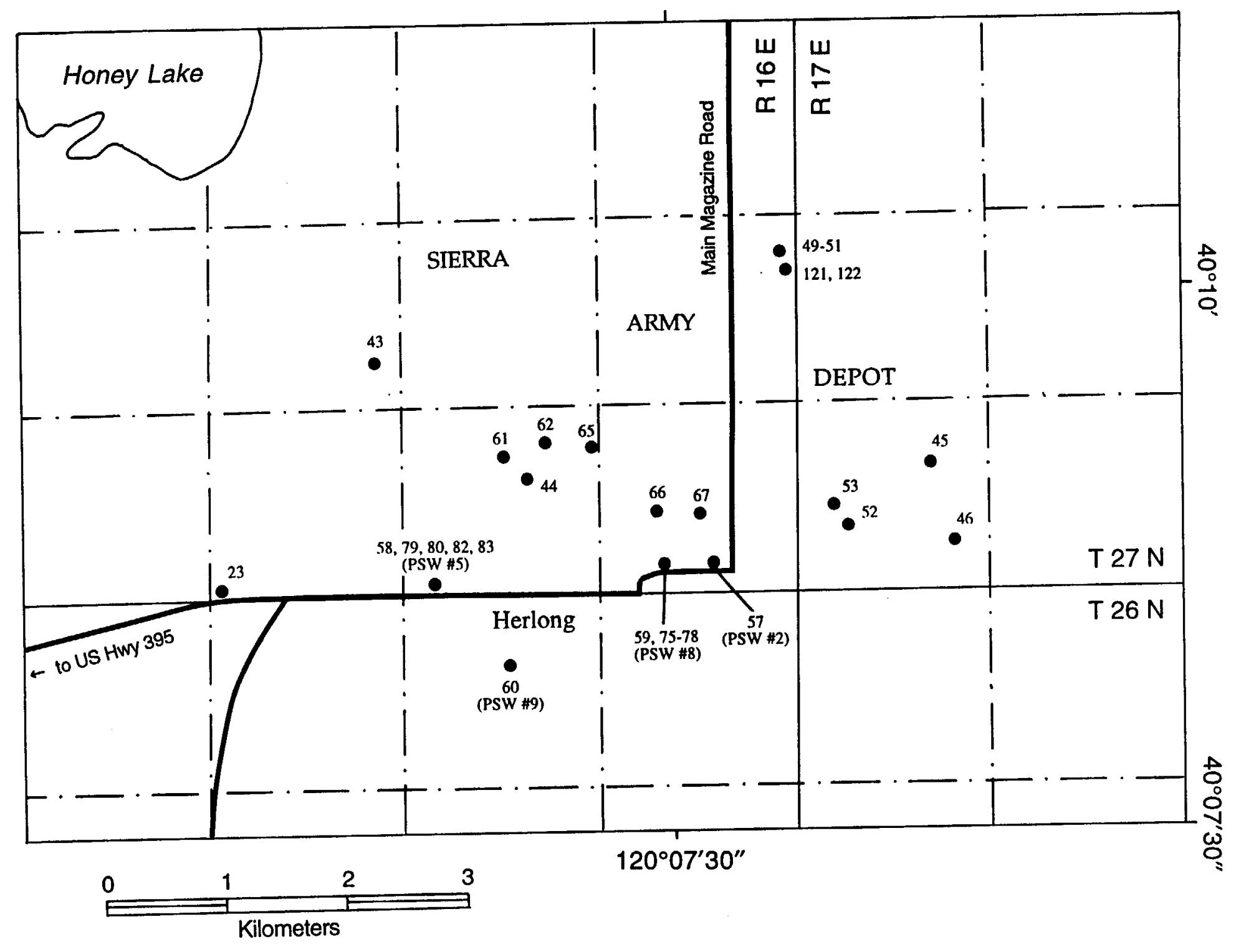




\section{Honey Lake Basin Groundwater}

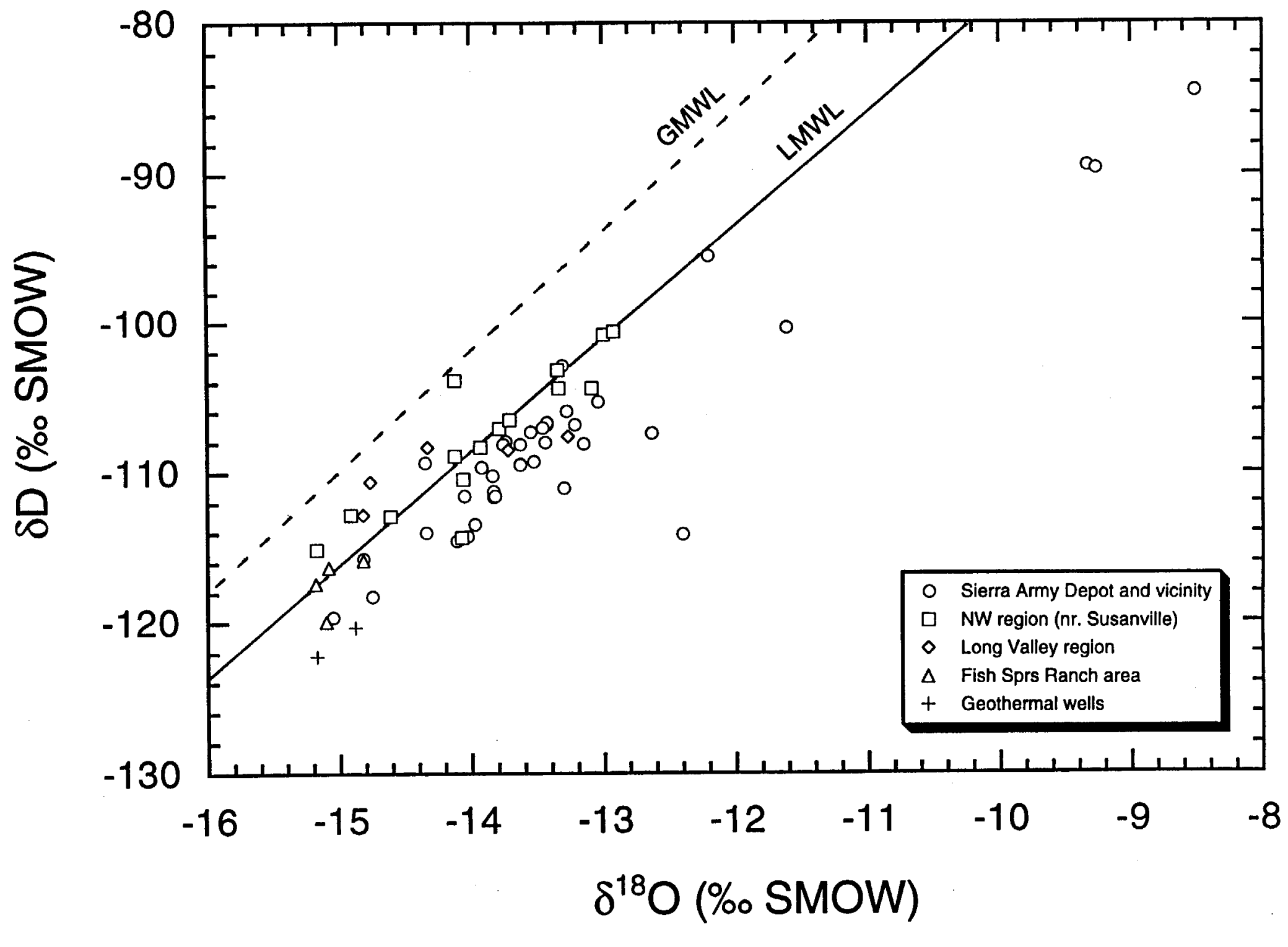




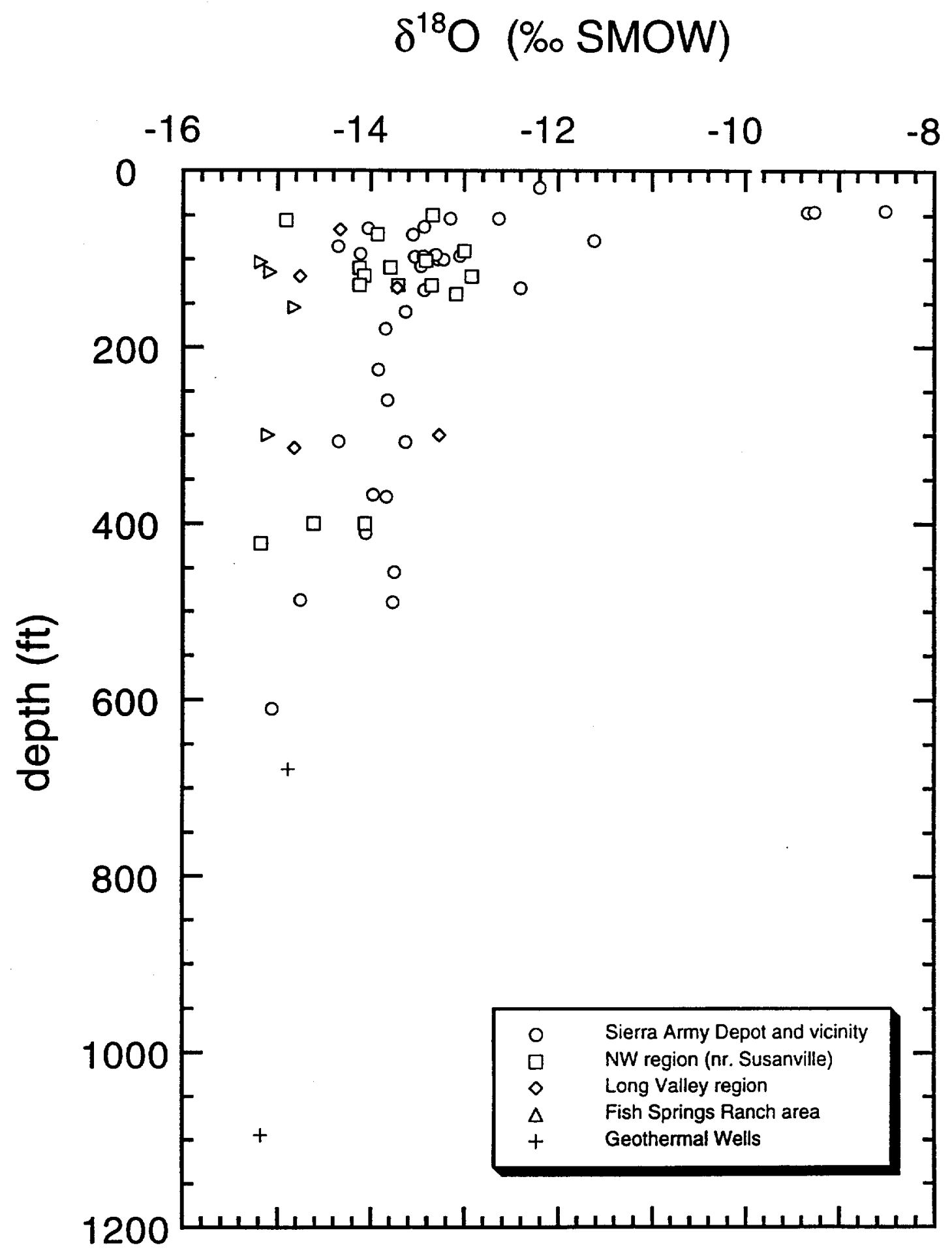

Figure 11 
$\delta^{18} \mathrm{O}(\%$ SMOW)

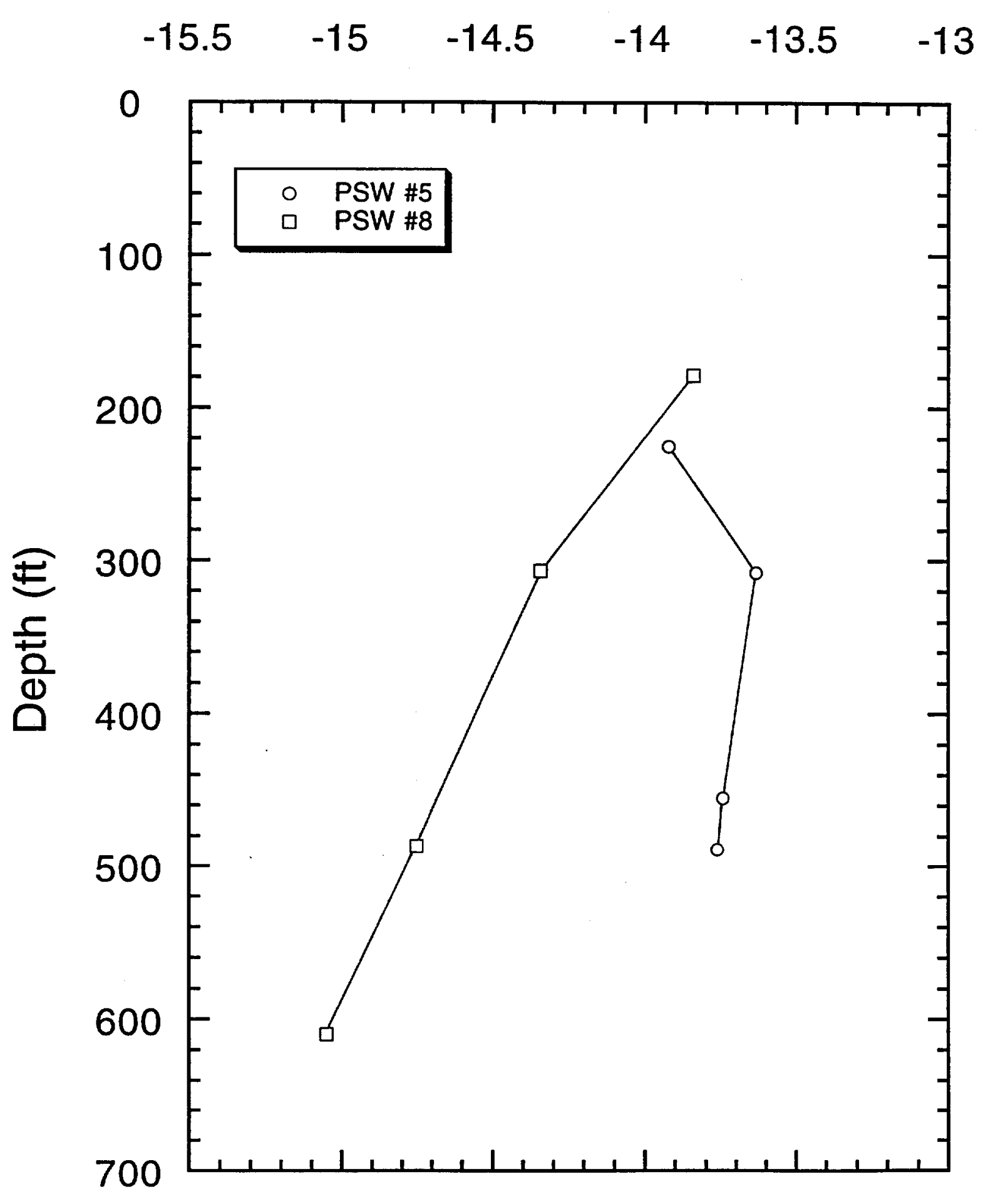

Figure 12 

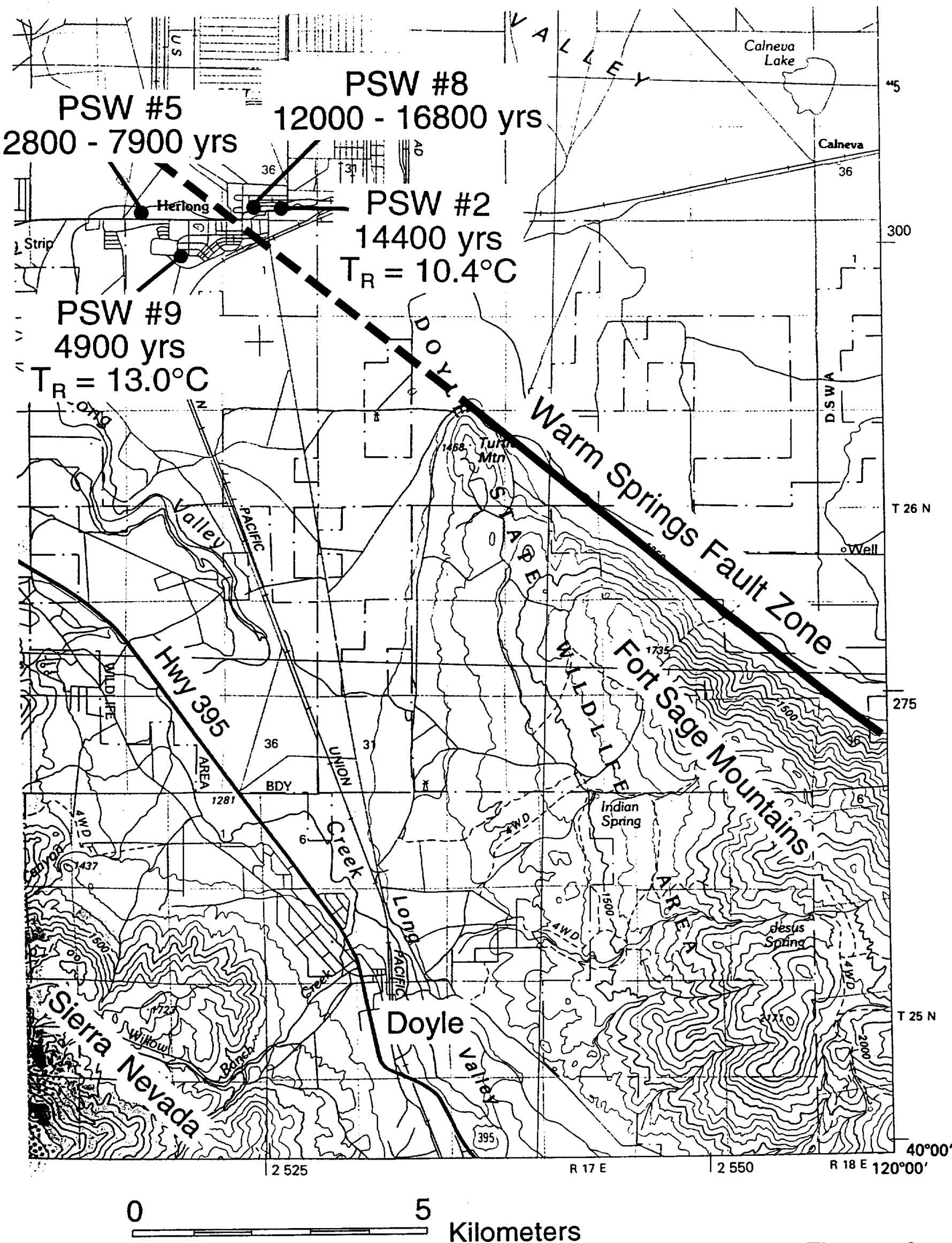

Figure 13 


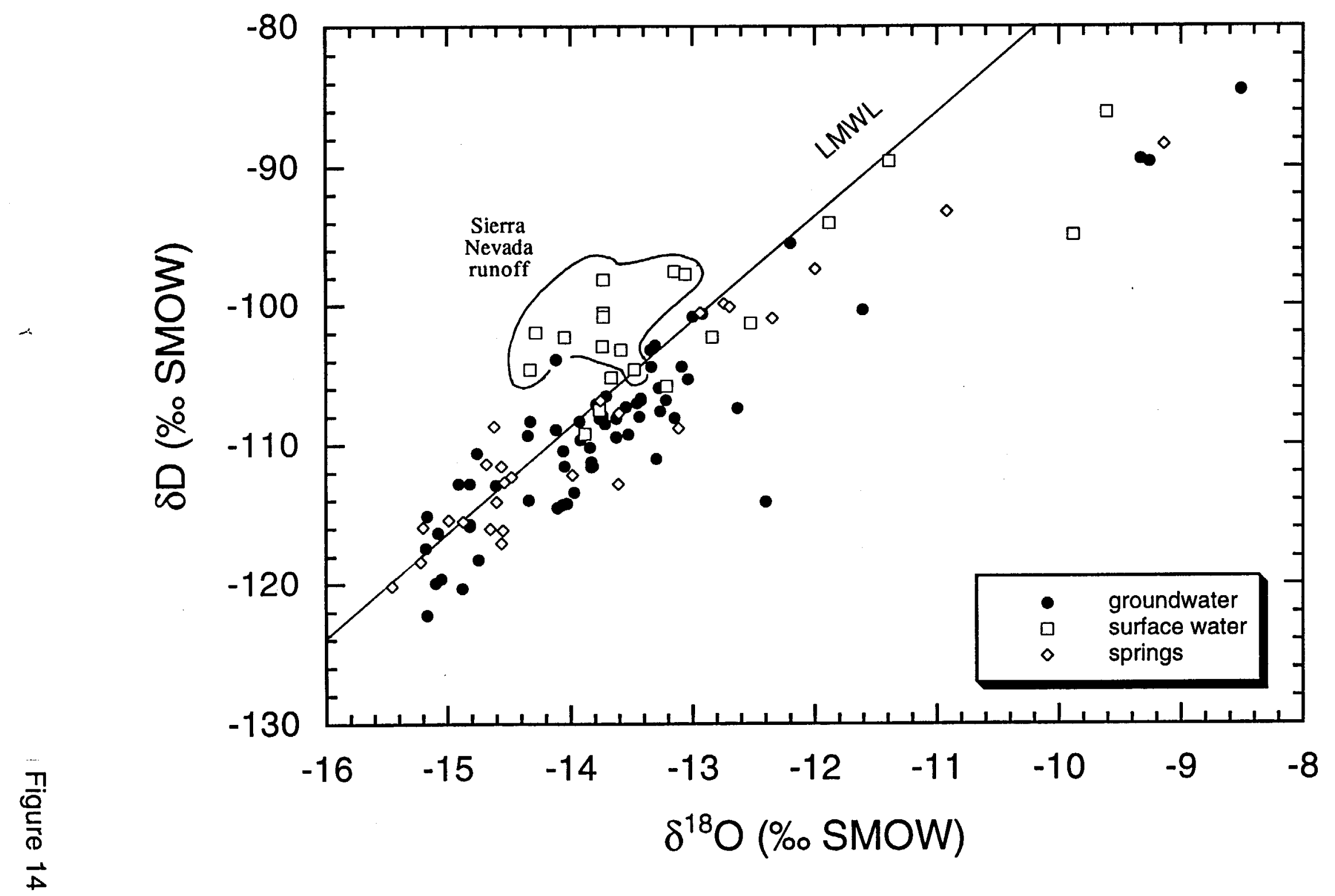




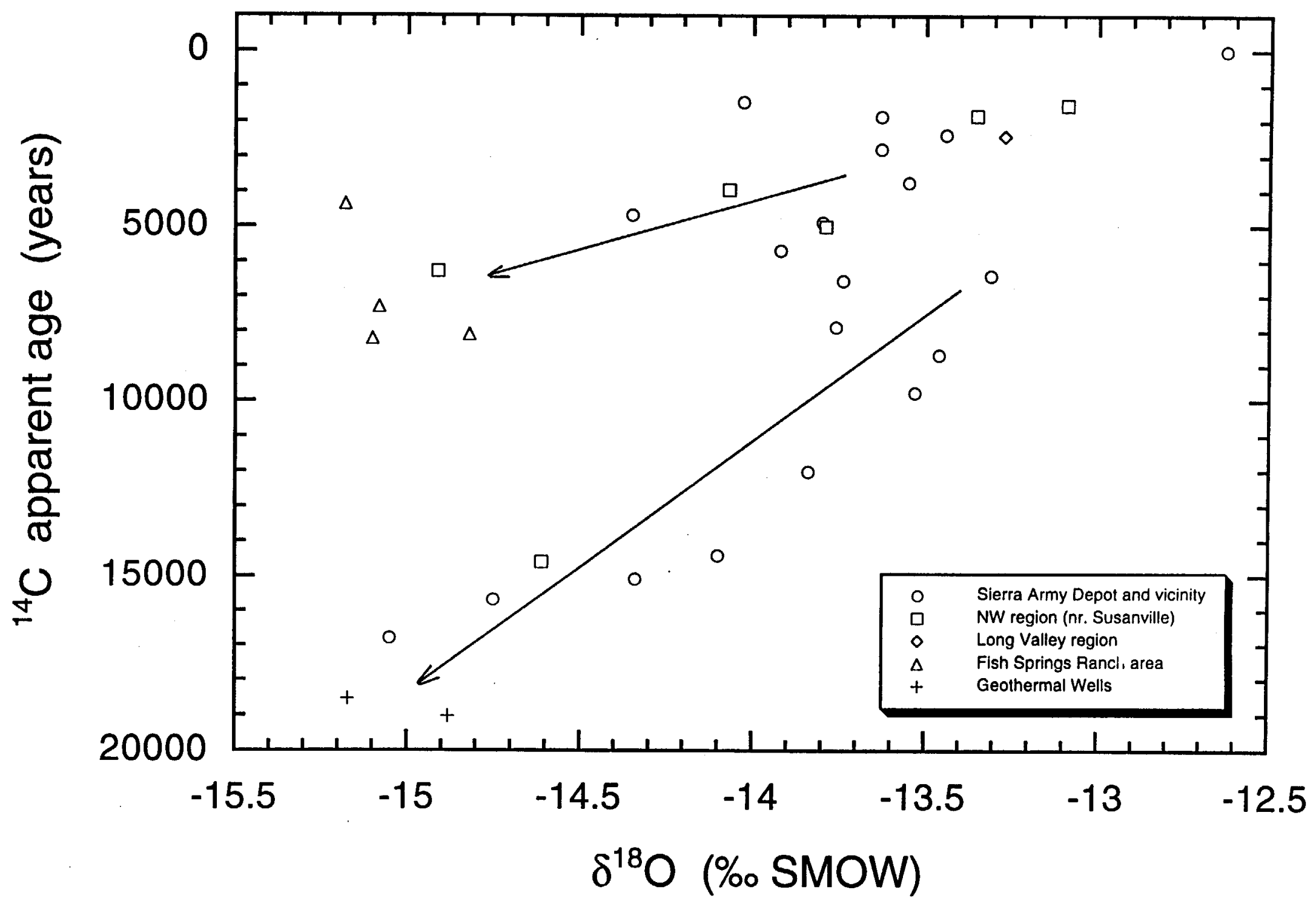




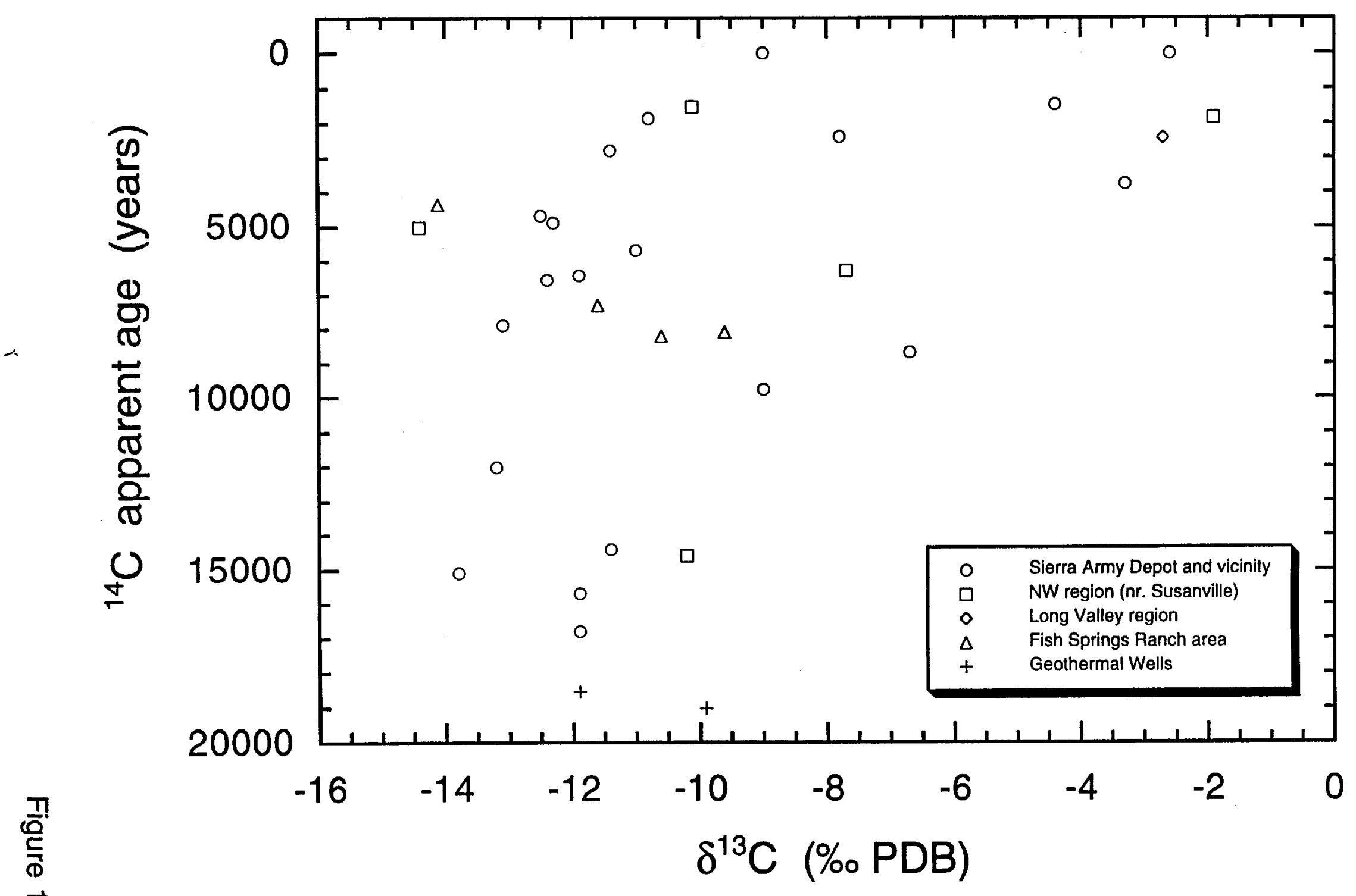




\section{${ }^{14} \mathrm{C}$ apparent age (years)}

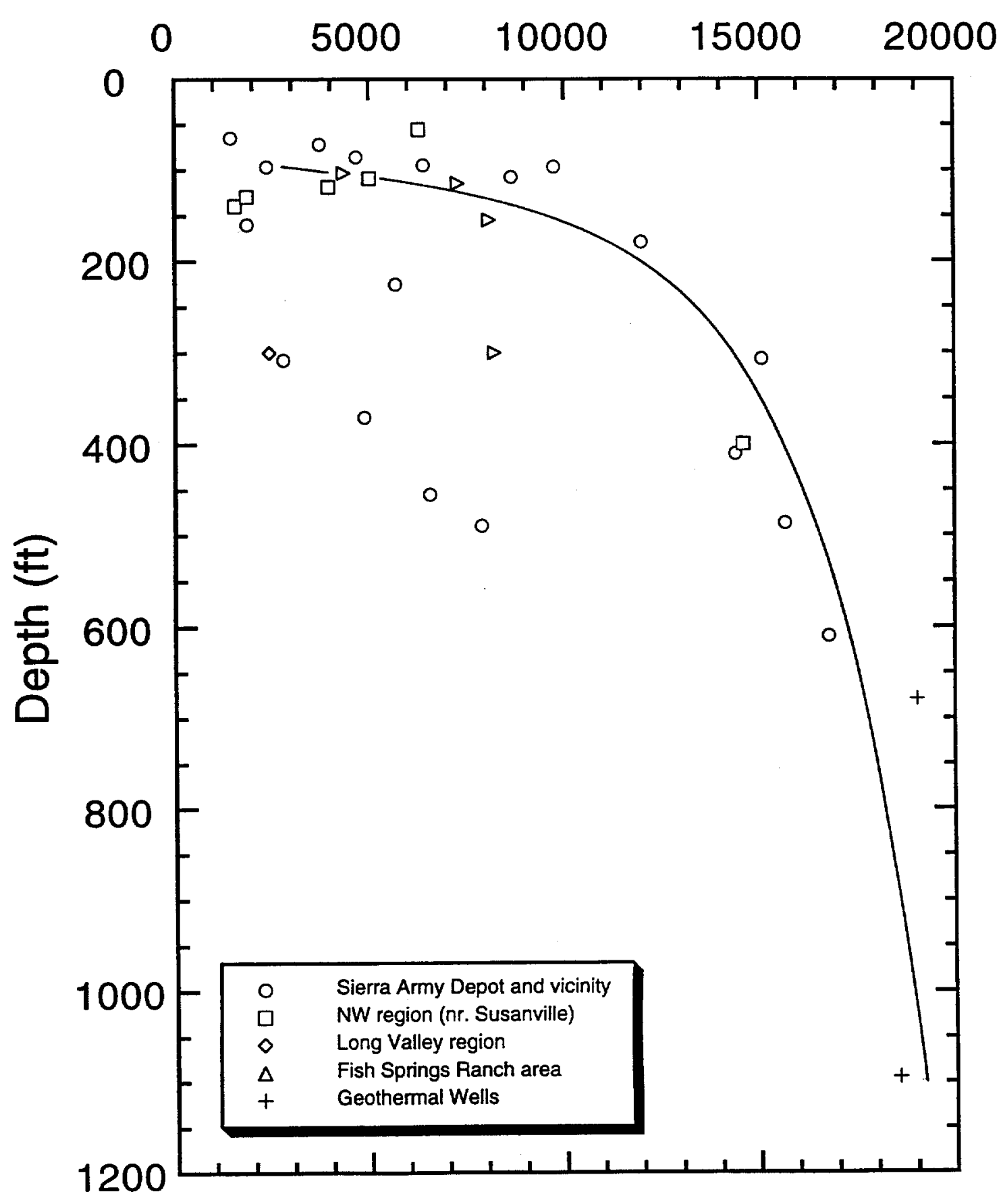

Figure 17 


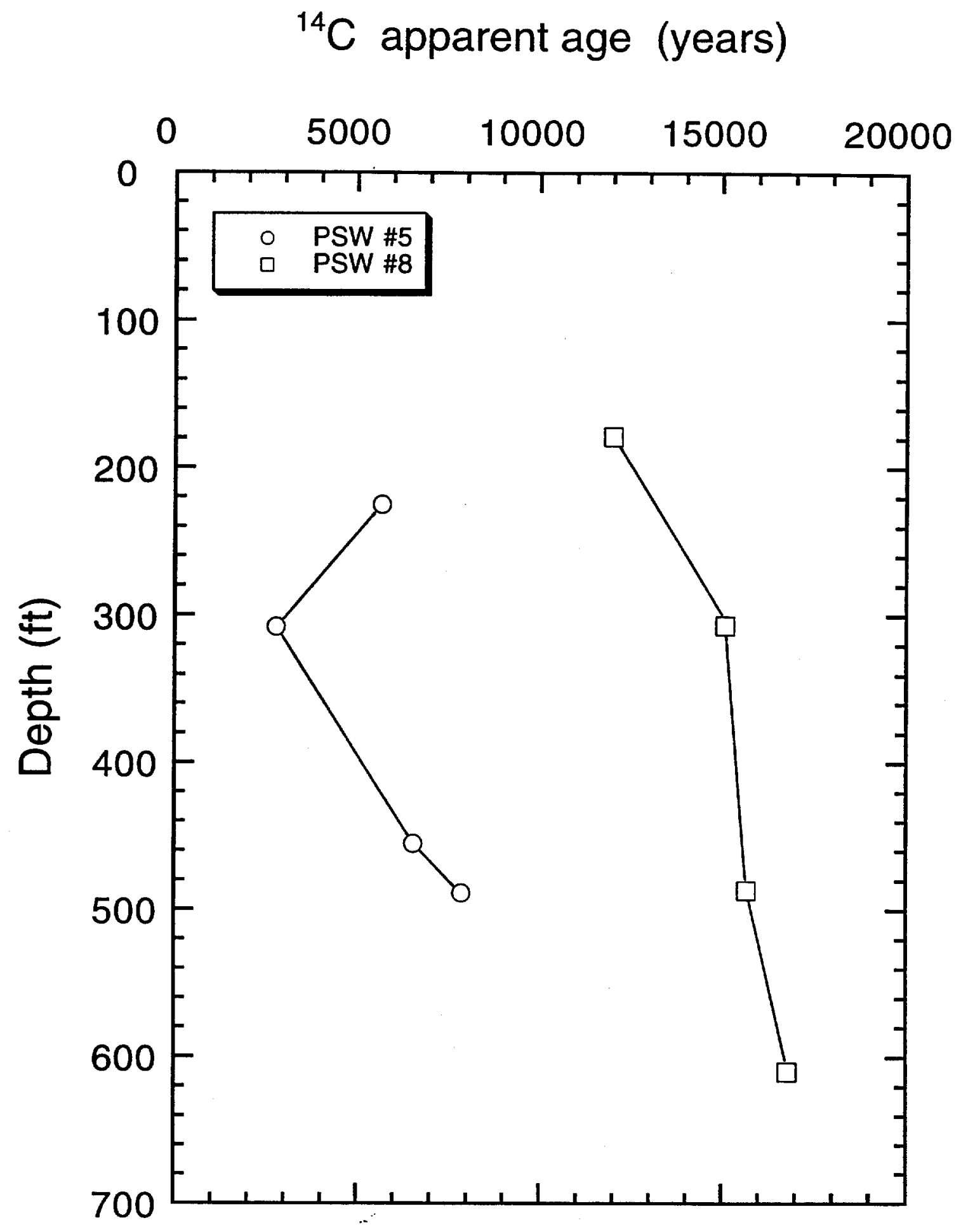

Figure 18 
Table 1. Chemical and Isotopic Data for Groundwater Samples

\begin{tabular}{|c|c|c|c|c|c|c|c|c|c|c|c|c|c|c|c|}
\hline $\begin{array}{l}\text { Sample } \\
\text { Number }\end{array}$ & Sample $\mathrm{ID}^{\dagger}$ & Location & Date & $\begin{array}{l}\text { Total } \\
\text { Depth } \\
\text { (ft) }\end{array}$ & $\begin{array}{l}\text { Perf. } \\
\text { Interval } \\
\text { (ft) }\end{array}$ & $\begin{array}{c}8^{18} \mathrm{O} \\
(\% \circ) \\
\text { (SMOW) }\end{array}$ & $\begin{array}{c}\delta \mathrm{D} \\
(\% o) \\
\text { (SMOW) }\end{array}$ & $\begin{array}{l}\delta^{13} \mathrm{C} \\
(\% o) \\
(\mathrm{PDB})\end{array}$ & $\begin{array}{c}{ }^{14} \mathrm{C} \\
(\mathrm{pmc})\end{array}$ & $\begin{array}{c}{ }^{14} \mathrm{C} \\
\text { app.age } \\
\text { (yrs) }\end{array}$ & $\begin{array}{l}\text { DIC } \\
(\mathrm{ppm} \\
\left.\mathrm{HCO}_{3}\right)\end{array}$ & $\begin{array}{c}\text { alkalinity } \\
(\mathrm{ppm} \\
\left.\mathrm{CaCO}_{3}\right)\end{array}$ & $\begin{array}{l}\text { cond } \\
\left(\mu \mathrm{S} \mathrm{cm}^{-1}\right)\end{array}$ & $\mathrm{pH}$ & $\mathrm{T}\left({ }^{\circ} \mathrm{C}\right)$ \\
\hline 006 & Lassen County well (i) & 29N14E-20NE & $06 / 18 / 95$ & 140 & - & -13.1 & -104 & -10.1 & 83.0 & 1540 & 460 & 350 & 2070 & 7.5 & 15.6 \\
\hline 007 & Standish (d) & 29N13E-14NE & $06 / 18 / 95$ & 144 & $81-140$ & -14.1 & -104 & -8.0 & - & - & 132 & 160 & 456 & 8.0 & 18.5 \\
\hline 008 & Johnstonville (d) & 29N13E-7SE & $06 / 19 / 95$ & 72 & - & -13.9 & -108 & - & - & - & - & 133 & 302 & 7.2 & 13.8 \\
\hline 009 & NW of Standish (d) & 29N13E-2SW & $06 / 19 / 95$ & 56 & - & -14.9 & -113 & -7.7 & 46.7 & 6295 & 86 & 117 & 351 & 7.9 & 14.9 \\
\hline 012 & SE of Standish (d) & 29N14E-22SE & $06 / 20 / 95$ & 91 & - & -13.0 & -101 & - & - & - & - & - & 431 & 7.5 & 16.7 \\
\hline 013 & Richmond School (d) & $29 \mathrm{~N} 12 \mathrm{E}-16 \mathrm{SW}$ & $11 / 14 / 95$ & 145 & $75-145$ & -13.8 & -107 & -14.4 & 54.5 & 5020 & 92 & 94 & 183 & 7.7 & 14.4 \\
\hline 023 & W of Herlong (d) & $26 \mathrm{~N} 16 \mathrm{E}-3 \mathrm{NW}$ & $07 / 05 / 95$ & 80 & $64-80$ & -13.6 & -107 & -3.3 & 63.6 & 3740 & 108 & 187 & 557 & 8.3 & 18.6 \\
\hline 025 & S of Doyle (d) & $25 \mathrm{~N} 17 \mathrm{E}-29 \mathrm{NE}$ & $07 / 06 / 95$ & 80 & $54-80$ & -14.3 & -108 & +0.4 & - & - & 25 & 85 & 215 & 6.8 & 21.4 \\
\hline 026 & $S$ of Doyle (d) & $25 N 17 E-21 S W$ & $07 / 06 / 95$ & 120 & - & -14.8 & -111 & - & - & - & - & 85 & 211 & 6.8 & 18.3 \\
\hline 027 & S of Doyle (a) & 25N17E-33SE & $07 / 06 / 95$ & 600 & $30-600$ & -14.8 & -113 & - & - & - & - & 95 & 237 & 8.1 & 22.4 \\
\hline 028 & SE of Herlong Jct. (d) & $26 \mathrm{~N} 16 \mathrm{E}-16 \mathrm{SE}$ & $07 / 07 / 95$ & 700 & $85-650$ & -14.0 & -113 & - & - & - & - & 138 & 457 & 7.2 & 19.3 \\
\hline 029 & NE of Hertong Jct. (d) & $26 \mathrm{~N} 16 \mathrm{E}-16 \mathrm{NW}$ & $07 / 07 / 95$ & 75 & $55-75$ & -14.0 & -114 & -4.4 & 83.8 & 1460 & 89 & 141 & 455 & 7.3 & 20.9 \\
\hline 030 & E of Doyle (d) & 25N17E-4SW & $08 / 08 / 95$ & 350 & $250-350$ & -13.3 & -108 & -2.7 & 74.6 & 2420 & 63 & 125 & 412 & 7.4 & 22.2 \\
\hline 031 & SW of Bass Hill (d) & 28N13E-5NE & $08 / 10 / 95$ & 200 & $40-200$ & -12.9 & -101 & - & 112.4 & modern & 37 & 110 & 219 & 6.9 & 20.0 \\
\hline 032 & $\mathrm{~N}$ of Buntingville (d) & $28 \mathrm{~N} 13 \mathrm{E}-2 \mathrm{SWa}$ & $08 / 10 / 95$ & 198 & $40-198$ & -14.1 & -114 & - & 62.0 & 3950 & 22 & 100 & 451 & 9.7 & 21.7 \\
\hline 033 & $\mathrm{~N}$ of Buntingville (d) & $28 \mathrm{~N} 13 \mathrm{E}-2 \mathrm{SWb}$ & $08 / 10 / 95$ & 400 & - & -14.1 & -110 & - & - & - & - & 80 & 429 & 9.7 & 21.6 \\
\hline 034 & Buntingville (d) & $28 \mathrm{~N} 13 \mathrm{E}-14 \mathrm{NW}$ & $08 / 10 / 95$ & 130 & - & -13.7 & -107 & - & - & - & - & 97 & 158 & 7.2 & 17.8 \\
\hline 035 & NW shore Honey L. (d) & 28N14E-18SE & $08 / 10 / 95$ & 100 & 0.100 & -13.3 & -104 & -2.6 & - & - & 72 & 105 & 350 & 7.6 & 17.4 \\
\hline 037 & Lake Crest Dr. (d) & $28 \mathrm{~N} 13 \mathrm{E}-25 \mathrm{SE}$ & $08 / 10 / 95$ & 140 & $120-140$ & -14.1 & -109 & - & $\cdot$ & - & - & 95 & 181 & 6.9 & 17.9 \\
\hline 038 & Carson-Litchfield (g) & 30N13E-36SW & $11 / 14 / 95$ & 1420 & $775-1414$ & -15.2 & -122 & -11.9 & 10.6 & 18550 & 19 & 40 & 1000 & 8.8 & 74.5 \\
\hline 039 & BLM well (a) & 29N15E-8SE & $08 / 11 / 95$ & 150 & $110-150$ & -13.4 & -103 & -1.9 & 79.9 & 1855 & 102 & 110 & 582 & 7.7 & 18.1 \\
\hline 040 & Wendel-Amedee-2 (g) & 28N16E-8NE & $08 / 11 / 95$ & 1058 & $312-1047$ & -14.9 & -120 & -9.9 & 10.0 & 19035 & 29 & 50 & 1750 & 7.0 & 98.9 \\
\hline 041 & Lee Rd. (d) & 29N16E-30NE & $08 / 11 / 95$ & 400 & - & -14.6 & -113 & -10.2 & 17.1 & 14600 & 97 & 75 & 388 & 8.2 & 22.6 \\
\hline 042 & SIAD UBG-4-MWA (m) & 28N17E-21NW & $08 / 23 / 95$ & 97 & $76-96$ & -14.4 & -109 & -12.5 & 56.8 & 4675 & 220 & 180 & 575 & 9.0 & 20.6 \\
\hline 043 & SIAD LF-1 (m) & 27N16E-27SE & $08 / 23 / 95$ & 65 & $43-65$ & -12.6 & -107 & -9.0 & 102.6 & modern & 606 & 500 & 1750 & 8.2 & 18.6 \\
\hline 044 & SIAD STP-2 (m) & 27N16E-35NE & $08 / 23 / 95$ & 58 & $37-57$ & -9.3 & -89 & - & - & - & $\cdot$ & 300 & 2320 & 6.9 & 18.3 \\
\hline 045 & SIAD B21-3-MW (m) & $27 \mathrm{~N} 17 \mathrm{E}-31 \mathrm{NE}$ & $09 / 25 / 95$ & 120 & $85-105$ & -13.3 & -103 & -11.9 & 46.0 & 6420 & 450 & 320 & 2170 & 7.3 & 18.9 \\
\hline 046 & SIAD B21-5-PZ (m) & 27N17E-31SE & $09 / 25 / 95$ & 105 & $90-105$ & -13.5 & -109 & -9.0 & 30.7 & 9760 & 221 & 170 & 2660 & 7.4 & 18.3 \\
\hline 049 & SIAD TNT-7-MWA (m) & $27 \mathrm{~N} 16 \mathrm{E}-25 \mathrm{NE}$ & $10 / 04 / 95$ & 69 & 58.68 & -13.4 & -107 & -7.9 & - & - & 224 & 245 & 1210 & 9.1 & 14.4 \\
\hline 050 & SIAD TNT-7-MWB (m) & $27 \mathrm{~N} 16 \mathrm{E}-25 \mathrm{NE}$ & $10 / 04 / 95$ & 104 & $92-102$ & -13.4 & -108 & -7.8 & 75.0 & 2380 & 271 & 245 & 1280 & 8.1 & 14.8 \\
\hline 051 & SIAD TNT-7-MWC (m) & $27 \mathrm{~N} 16 \mathrm{E}-25 \mathrm{NE}$ & $10 / 04 / 95$ & 147 & $130-140$ & -13.4 & -107 & -13.4 & - & - & 286 & 245 & 1190 & 7.9 & 14.9 \\
\hline 052 & SIAD DMO-13-A (m) & 27N17E-31SW & $10 / 11 / 95$ & 119 & $98-118$ & -13.5 & -107 & -6.7 & 35.0 & 8680 & 98 & 118 & 1210 & 7.7 & 18.1 \\
\hline 053 & SIAD DMO-11-A (m) & $27 N 17 E-31 S W$ & $10 / 11 / 95$ & 110 & $90-110$ & -13.3 & -106 & - & - & - & - & 70 & 1330 & 7.5 & 17.6 \\
\hline 055 & NCCC PA-12 (i) & $29 \mathrm{~N} 13 \mathrm{E}-2 \mathrm{~N}$ & $08 / 11 / 95$ & 660 & $185-660$ & -15.2 & -115 & - & - & - & - & - & - & 8.5 & 31.7 \\
\hline 057 & SIAD PSW \#2 (i) & $27 \mathrm{~N} 16 \mathrm{E}-36 \mathrm{SE}$ & $11 / 14 / 95$ & 700 & $167-655$ & -14.1 & -112 & -11.4 & 17.5 & 14410 & 205 & 175 & 1119 & 8.2 & 16.9 \\
\hline
\end{tabular}


Table 1. (continued)

\begin{tabular}{|c|c|c|c|c|c|c|c|c|c|c|c|c|c|c|c|}
\hline $\begin{array}{l}\text { Sample } \\
\text { Number }\end{array}$ & Sample $\mathrm{ID}^{\dagger}$ & Location & Date & $\begin{array}{l}\text { Total } \\
\text { Depth } \\
\text { (ft) }\end{array}$ & $\begin{array}{l}\text { Perf. } \\
\text { Interval } \\
\text { (ft) }\end{array}$ & $\begin{array}{c}\delta^{18} O \\
(\% \circ) \\
(\mathrm{SMOW})\end{array}$ & $\begin{array}{c}\delta \mathrm{D} \\
(\% \circ) \\
(\mathrm{SMOW})\end{array}$ & $\begin{array}{l}\delta^{13} \mathrm{C} \\
(\% \circ) \\
(\mathrm{PDB})\end{array}$ & ${ }_{(\mathrm{pmc})}^{14 \mathrm{C}}$ & $\begin{array}{c}{ }^{14} \mathrm{C} \\
\text { app.age } \\
\text { (yrs) }\end{array}$ & $\begin{array}{l}\text { DIC } \\
(\mathrm{ppm} \\
\left.\mathrm{HCO}_{3}\right)\end{array}$ & $\begin{array}{c}\text { alkalinity } \\
(\mathrm{ppm} \\
\left.\mathrm{CaCO}_{3}\right)\end{array}$ & $\begin{array}{l}\text { cond } \\
\left(\mu \mathrm{Sm}^{-1}\right)\end{array}$ & $\mathrm{pH}$ & $\mathrm{T}\left({ }^{\circ} \mathrm{C}\right)$ \\
\hline 058 & SIAD PSW \#5 (i) & $27 N 16 \mathrm{E}-35 S W$ & $11 / 14 / 95$ & 550 & $180-540$ & -13.6 & -109 & -11.8 & 60.9 & 4100 & 213 & 160 & 697 & 8.5 & 17.1 \\
\hline 059 & SIAD PSW \#8 (i) & $27 \mathrm{~N} 16 \mathrm{E}-36 \mathrm{SW}$ & $11 / 14 / 95$ & 700 & $165-690$ & -13.8 & -112 & -11.9 & 30.7 & 9760 & 201 & 160 & 955 & 8.3 & 16.7 \\
\hline 060 & SIAD PSW \#9 (i) & 26N16E-2NE & $11 / 14 / 95$ & 530 & $220-520$ & -13.8 & -111 & -12.3 & 55.4 & 4880 & 200 & 150 & 433 & 8.1 & 18.3 \\
\hline 061 & SIAD STP-3-PZ (m) & $27 \mathrm{~N} 16 \mathrm{E}-35 \mathrm{NW}$ & $12 / 20 / 95$ & 56 & $36-56$ & -9.3 & -90 & - & - & - & - & - & 1790 & 7.2 & 13.1 \\
\hline 062 & SIAD STP-4-PZ (m) & 27N16E-35NE & $12 / 20 / 95$ & 57 & $35-55$ & -8.5 & -85 & - & - & - & - & - & 1940 & 6.7 & 11.8 \\
\hline 064 & SIAD STP-7 (m) & $27 \mathrm{~N} 16 \mathrm{E}-36 \mathrm{E}$ & $12 / 20 / 95$ & 68 & $44-64$ & -13.1 & -108 & - & - & $\cdot$ & - & - & 1710 & 7.9 & 13.7 \\
\hline 065 & SIAD STP-5-PZ (m) & $27 \mathrm{~N} 16 \mathrm{E}-35 \mathrm{NE}$ & $12 / 20 / 95$ & 91 & 69.89 & -11.6 & -100 & - & - & - & - & - & 1250 & 7.7 & 14.1 \\
\hline 066 & SIAD ALF-8-MWA (m) & $27 N 16 E-36 S W$ & $12 / 20 / 95$ & 110 & $90-110$ & -13.2 & -107 & - & - & - & - & - & 1630 & 7.6 & 11.8 \\
\hline 067 & SIAD ALF-3 (m) & $27 N 16 E-36 S E$ & $12 / 20 / 95$ & 106 & $86-106$ & -13.0 & -105 & - & - & - & - & - & 1820 & 7.7 & 12.9 \\
\hline 068 & SIAD LBG-2 (m) & 28N16E-24SE & $01 / 24 / 96$ & 33 & $9-29$ & -12.2 & -96 & - & - & - & - & - & 11340 & 8.7 & 13.6 \\
\hline 075 & SIAD PSW \#8 PZ-3 (m) & $27 \mathrm{~N} 16 \mathrm{E}-36 \mathrm{SW}$ & $01 / 30 / 96$ & 495 & $482-492$ & -14.7 & -118 & -11.9 & 15.0 & 15680 & 256 & 180 & 864 & 8.1 & - \\
\hline 076 & SIAD PSW \#8 PZ-2 (m) & $27 \mathrm{~N} 16 \mathrm{E}-36 \mathrm{SW}$ & $01 / 30 / 96$ & 335 & $302-312$ & -14.3 & -114 & -13.8 & 16.1 & 15100 & 214 & 180 & 928 & 8.3 & - \\
\hline 077 & SIAD PSW \#8 PZ-4 (m) & $27 N 16 E-36 S W$ & $01 / 30 / 96$ & 630 & $605-615$ & -15.1 & -120 & -11.9 & 13.1 & 16800 & 204 & 165 & 818 & 8.1 & - \\
\hline 078 & SIAD PSW \#8 PZ-1 (m) & $27 \mathrm{~N} 16 \mathrm{E}-36 \mathrm{SW}$ & $01 / 30 / 96$ & 185 & $174-184$ & -13.8 & -110 & -13.2 & 23.4 & 12010 & 208 & 165 & 1220 & 8.1 & - \\
\hline 079 & SIAD PSW \#5 PZ-2 (m) & $27 \mathrm{~N} 16 \mathrm{E}-35 S W$ & $01 / 31 / 96$ & 315 & $303-313$ & -13.6 & -110 & -11.4 & 71.4 & 2785 & 249 & 180 & 917 & 7.7 & - \\
\hline 080 & SIAD PSW \#5 PZ-1 (m) & $27 \mathrm{~N} 16 \mathrm{E}-35 \mathrm{SW}$ & $01 / 31 / 96$ & 232 & $220-230$ & -13.9 & -110 & -11.0 & 50.3 & 5690 & 215 & 179 & 596 & 7.6 & - \\
\hline 082 & SIAD PSW \#5 PZ-3 (m) & $27 \mathrm{~N} 16 \mathrm{E}-35 \mathrm{SW}$ & $01 / 31 / 96$ & 463 & 450.460 & -13.7 & -108 & -12.4 & 45.2 & 6560 & 212 & 170 & 883 & - & - \\
\hline 083 & SIAD PSW \#5 PZ-4 (m) & $27 \mathrm{~N} 16 \mathrm{E}-35 \mathrm{SW}$ & $01 / 31 / 96$ & 600 & $484-494$ & -13.8 & -108 & -13.1 & 38.5 & 7890 & 225 & 180 & 822 & - & - \\
\hline 089 & Artesian Well & 28N17E-19NE & $03 / 12 / 96$ & • & - & -14.8 & -116 & -10.4 & - & - & 82 & 85 & 285 & 8.8 & 21.1 \\
\hline 110 & Fish Sprs Ranch (a) & 26N18E-26NE & $04 / 09 / 96$ & 440 & $160-440$ & -15.1 & -122 & -11.9 & - & - & 115 & 105 & 747 & 8.1 & 17.6 \\
\hline $110 b$ & Fish Sprs Ranch (a) & $26 \mathrm{~N} 18 \mathrm{E}-26 \mathrm{NE}$ & $08 / 15 / 96$ & 440 & $160-440$ & -15.1 & -120 & -10.6 & 37.0 & 8220 & 98 & - & - & - & - \\
\hline 121 & SIAD TNT-1-MWB (m) & $27 \mathrm{~N} 16 \mathrm{E}-25 \mathrm{NE}$ & $01 / 23 / 96$ & 103 & $90-100$ & -13.3 & -111 & - & - & - & - & - & - & - & - \\
\hline 122 & SIAD TNT-1 MWC (m) & $27 \mathrm{~N} 16 \mathrm{E}-25 \mathrm{NE}$ & $01 / 23 / 96$ & 147 & $128-138$ & -12.4 & -114 & - & - & - & - & - & - & - & $\cdot$ \\
\hline 123 & SIAD DEMO-1 (m) & $28 \mathrm{~N} 17 \mathrm{E}-16 \mathrm{SE}$ & $04 / 16 / 96$ & 94 & - & -14.1 & -115 & -10.2 & : & - & 218 & - & 800 & - & 26.7 \\
\hline 125 & Constantia (d) & $25 \mathrm{~N} 17 \mathrm{E}-20$ & $06 / 03 / 96$ & 180 & $85-180$ & -13.7 & -109 & - & - & - & - & - & - & - & - \\
\hline 126 & JDS Wetlands (a) & $27 \mathrm{~N} 16 \mathrm{E}-18 S \mathrm{~W}$ & $06 / 10 / 96$ & 160 & - & -13.6 & -108 & -10.8 & 79.8 & 1860 & 690 & 500 & 1950 & 8.6 & 18.2 \\
\hline 127 & JDS Wetlands (d) & $27 \mathrm{~N} 15 \mathrm{E}-13 \mathrm{E}$ & $06 / 10 / 96$ & 260 & - & -13.8 & -112 & -6.8 & - & - & 248 & 210 & 545 & 9.0 & 17.9 \\
\hline 149 & Fish Sprs Ranch (d) & $26 \mathrm{~N} 19 \mathrm{E}-20 \mathrm{SW}$ & $08 / 15 / 96$ & 258 & $52-258$ & -14.8 & -116 & -9.6 & 37.6 & 8100 & 159 & - & - & - & - \\
\hline 151 & Fish Sprs Ranch (a) & $26 \mathrm{~N} 19 \mathrm{E}-29 \mathrm{NE}$ & $08 / 15 / 96$ & 215 & $80-150$ & -15.1 & -116 & -11.6 & 41.3 & 7300 & 103 & - & - & - & - \\
\hline 152 & Cal Neva Rd. (m) & $26 \mathrm{~N} 17 \mathrm{E}-13 \mathrm{NW}$ & $08 / 15 / 96$ & 109 & $99-109$ & -15.2 & -117 & -14.1 & 59.0 & 4360 & 140 & - & - & - & - \\
\hline
\end{tabular}

† Letters in parentheses designate the principal use for each well: $a=$ agricultural irrigation well; $d=$ domestic well; $g=$ geothermal production well; $i=$ industrial/municipal production well; $m=$ monitoring well.

Slash mark $(-)=$ not determined or unavailable 
Table 2. Chemical and Isotopic Data for Springs and Surface Waters

\begin{tabular}{|c|c|c|c|c|c|c|c|c|c|c|c|}
\hline $\begin{array}{l}\text { Sample } \\
\text { Number }\end{array}$ & Sample ID & Location & Date & $\begin{array}{c}\delta^{18} \mathrm{O} \\
(\% \circ \text { SMOW })\end{array}$ & $\begin{array}{c}\delta \mathrm{D} \\
(\% \circ \text { SMOW) }\end{array}$ & $\begin{array}{c}\delta^{13} \mathrm{C} \\
(\% \circ \mathrm{PDB})\end{array}$ & $\begin{array}{c}\text { Dissolved } \\
\text { Inorganic Carbon } \\
\left(\mathrm{ppm} \mathrm{HCO}_{3}^{-}\right)\end{array}$ & $\begin{array}{c}\text { alkalinity } \\
\left(\text { ppm } \mathrm{CaCO}_{3}\right)\end{array}$ & $\begin{array}{l}\text { conductivity } \\
(\mu \mathrm{S} \mathrm{cm}-1)\end{array}$ & $\mathrm{pH}$ & $\mathrm{T}\left({ }^{\circ} \mathrm{C}\right)$ \\
\hline 001 & Skedaddle Creek & 28N17E-23SW & $05 / 15 / 95$ & -12.8 & -102 & - & - & - & - & - & - \\
\hline $001 b$ & Skedaddle Creek & 28N17E-23SW & $02 / 03 / 96$ & -13.7 & -105 & - & - & - & 70 & - & 6.4 \\
\hline 002 & Long Valley Creek & $25 \mathrm{~N} 16 \mathrm{E}-1 \mathrm{NE}$ & $06 / 17 / 95$ & -13.7 & -103 & -6.5 & 105 & 120 & 311 & 8.3 & 18.6 \\
\hline 003 & Milford Grade Creek & 27N14E-36NE & $06 / 17 / 95$ & -13.7 & -101 & - & - & 85 & 144 & 8.2 & 17.8 \\
\hline 004 & East Canyon Creek & $26 \mathrm{~N} 15 \mathrm{E}-6 \mathrm{SW}$ & $06 / 17 / 95$ & -14.3 & -105 & -5.2 & 34 & 70 & 127 & 7.9 & 17.2 \\
\hline 005 & McDermott Creek & $27 \mathrm{~N} 14 \mathrm{E}-36 \mathrm{NW}$ & $06 / 17 / 95$ & -14.3 & -102 & -2.8 & 54 & 100 & 189 & 8.2 & 18.8 \\
\hline 010 & Willow Creek & 29N14E-6SW & $06 / 20 / 95$ & -11.9 & -94 & -4.7 & 165 & 180 & 429 & 8.6 & 19.3 \\
\hline 011 & Susan R. @ Litchfield & $29 \mathrm{~N} 14 \mathrm{E}-15 \mathrm{NW}$ & $06 / 20 / 95$ & -13.1 & -98 & -0.3 & 36 & 75 & 136 & 8.1 & 18.9 \\
\hline 014 & Susan R. west of Susanville & 29N11E-6SE & $06 / 22 / 95$ & -13.1 & -98 & -2.4 & 12 & 35 & 52 & 7.4 & 17.8 \\
\hline 015 & Gold Run Creek & 29N11E-23SE & $06 / 22 / 95$ & -13.7 & -98 & - & - & 37 & 48 & 7.8 & 12.3 \\
\hline 016 & Elysian Creek & 28N13E-6SE & $06 / 22 / 95$ & -13.7 & -101 & - & - & 40 & 64 & 7.6 & 17.2 \\
\hline 017 & Parker Creek & 28N13E-15NW & $06 / 22 / 95$ & -14.1 & -102 & - & - & 50 & 110 & 7.7 & 12.4 \\
\hline 024 & Long Valley Creek & 26N16E-6SE & $07 / 05 / 95$ & -11.4 & -90 & - & - & 160 & 463 & 8.2 & 28.6 \\
\hline 036 & Brownell Creek & $28 \mathrm{~N} 13 \mathrm{E}-36 \mathrm{NE}$ & $08 / 10 / 95$ & -13.6 & -103 & - & - & 90 & 164 & 7.8 & 20.6 \\
\hline 047 & Honey Lake - East Arm & $27 \mathrm{~N} 15 \mathrm{E}-2 \mathrm{NE}$ & $09 / 30 / 95$ & -5.6 & -58 & .2 .6 & 422 & - & 917 & 9.0 & 23.9 \\
\hline 048 & Honey Lake - West Arm & $27 \mathrm{~N} 15 \mathrm{E}-20 \mathrm{NW}$ & $09 / 30 / 95$ & -4.9 & -57 & -2.0 & 287 & - & 713 & 8.8 & 24.4 \\
\hline 087 & Shaffer Spring & $29 \mathrm{~N} 15 \mathrm{E}-6 \mathrm{~N}$ & $02 / 03 / 96$ & -12.7 & -100 & - & - & - & 89 & - & 8.3 \\
\hline 090 & Spr. - NE of Stacy & $28 \mathrm{~N} 17 \mathrm{E}-25 \mathrm{SW}$ & $03 / 12 / 96$ & -14.6 & -114 & -10.1 & 114 & 110 & 300 & 8.9 & 15.0 \\
\hline 091 & Spr. - W Antelope Mtn. & $30 \mathrm{~N} 12 \mathrm{E}-13 \mathrm{SW}$ & $04 / 08 / 96$ & -12.9 & -101 & - & - & - & - & - & - \\
\hline 092 & Murrers Meadow Spring & $32 \mathrm{~N} 11 \mathrm{E}-35 \mathrm{SE}$ & $04 / 08 / 96$ & -14.6 & -112 & - & - & 110 & 210 & 7.6 & 15.5 \\
\hline 093 & Willow Creek & $31 \mathrm{~N} 11 \mathrm{E}-2 \mathrm{E}$ & $04 / 08 / 96$ & -13.2 & -106 & - & - & 130 & 286 & 7.8 & 10.4 \\
\hline 094 & Spr. - E Horse Lake Mtn. & $32 \mathrm{~N} 13 \mathrm{E}-29 \mathrm{SE}$ & $04 / 08 / 96$ & -15.0 & -115 & - & - & 120 & 207 & 8.4 & 11.9 \\
\hline 095 & Spr. - S Horse Mtn. & $33 \mathrm{~N} 14 \mathrm{E}-31 \mathrm{SE}$ & $04 / 08 / 96$ & -13.6 & -108 & - & - & 140 & 282 & 8.3 & 17.6 \\
\hline 096 & Fleming Spring & 33N14E-3E & $04 / 08 / 96$ & -13.8 & -107 & - & - & 58 & 121 & 8.3 & 16.8 \\
\hline 097 & Fleming Creek & $33 \mathrm{~N} 14 \mathrm{E}-3 \mathrm{E}$ & $04 / 08 / 96$ & -13.9 & -109 & - & - & - & 102 & 7.8 & 16.4 \\
\hline 098 & Tule Patch Spring & $32 \mathrm{~N} 15 \mathrm{E}-10 \mathrm{SE}$ & $04 / 08 / 96$ & -14.5 & -113 & - & - & 92 & 179 & 8.0 & 16.6 \\
\hline 099 & Spr. - S Snowstorm Mtn. & $31 \mathrm{~N} 15 \mathrm{E}-9 \mathrm{NW}$ & $04 / 08 / 96$ & -14.6 & -116 & - & - & 95 & 217 & 7.7 & 17.6 \\
\hline 100 & Railroad Spring & $31 \mathrm{~N} 14 \mathrm{E}-2 \mathrm{SW}$ & $04 / 08 / 96$ & -9.1 & -88 & - & - & 400 & 1660 & 7.9 & 19.1 \\
\hline 101 & Spr. - NW Five Sprs. Mtn. & $31 N 15 E-1 N W$ & $04 / 08 / 96$ & -14.6 & .117 & - & - & 115 & 274 & 8.0 & 15.7 \\
\hline 102 & Gilman Spring & $30 \mathrm{~N} 15 \mathrm{E}-8 \mathrm{SW}$ & $04 / 08 / 96$ & -12.0 & -97 & - & - & 80 & 172 & 8.1 & 18.9 \\
\hline
\end{tabular}


Table 2. (continued)

\begin{tabular}{|c|c|c|c|c|c|c|c|c|c|c|c|}
\hline $\begin{array}{l}\text { Sample } \\
\text { Number }\end{array}$ & Sample ID & Location & Date & $\begin{array}{c}\delta^{18} \mathrm{O} \\
(\% \text { SMOW })\end{array}$ & $\begin{array}{c}\delta \mathrm{D} \\
(\%, \text { SMOW) }\end{array}$ & $\begin{array}{c}\delta^{13} \mathrm{C} \\
(\% \circ \mathrm{PDB})\end{array}$ & $\begin{array}{c}\text { Dissolved } \\
\text { Inorganic Carbon } \\
\left(\mathrm{ppm} \mathrm{HCO}_{3}^{-}\right)\end{array}$ & $\begin{array}{c}\text { alkalinity } \\
\left(\mathrm{ppm} \mathrm{CaCO}_{3}\right)\end{array}$ & $\begin{array}{l}\text { conductivity } \\
\left(\mu \mathrm{cm}^{-1}\right)\end{array}$ & $\mathrm{pH}$ & $\mathrm{T}\left({ }^{\circ} \mathrm{C}\right)$ \\
\hline 103 & Zamboni Hot Spring & 24N17E-24NW & $04 / 09 / 96$ & -15.5 & -120 & -14.3 & 51 & 68 & 320 & 8.2 & 39.1 \\
\hline 104 & August Spring & 23N18E-9W & $04 / 09 / 96$ & -14.5 & -112 & - & - & 100 & 204 & 8.6 & 9.6 \\
\hline 105 & Spr. - E Seven Lakes Mtn. & 24N18E-26NE & $04 / 09 / 96$ & -12.4 & -101 & - & - & 75 & 138 & 8.3 & 15.0 \\
\hline 106 & Higgens Spring & 24N19E-18SE & $04 / 09 / 96$ & -14.6 & -116 & - & - & 150 & 434 & 7.9 & 14.2 \\
\hline 107 & Spr. - N Seven Lakes Mtn. & $24 \mathrm{~N} 18 \mathrm{E}-15 \mathrm{NE}$ & $04 / 09 / 96$ & -13.6 & -113 & - & - & 100 & 259 & 7.7 & 13.6 \\
\hline 108 & Spr. - E Fort Sage Mtns. & $25 \mathrm{~N} 18 \mathrm{E}-14 \mathrm{SW}$ & $04 / 09 / 96$ & -10.9 & -93 & - & - & 115 & 286 & 7.9 & 20.3 \\
\hline 109 & Spr. - NE Fort Sage Mtns. & $25 \mathrm{~N} 18 \mathrm{E}-4 \mathrm{SW}$ & $04 / 09 / 96$ & -14.9 & -116 & - & - & 130 & 307 & 8.0 & 10.3 \\
\hline 111 & E Cottonwood Canyon Spr. & $26 \mathrm{~N} 19 \mathrm{E}-26 \mathrm{NW}$ & $04 / 09 / 96$ & -15.2 & -118 & - & - & 85 & 182 & 8.1 & 15.5 \\
\hline 112 & E Cottonwood Canyon Ck. & $26 \mathrm{~N} 19 \mathrm{E}-23 \mathrm{SW}$ & $04 / 09 / 96$ & -13.8 & -108 & - & - & 62 & 149 & 8.3 & 14.1 \\
\hline 113 & Indian Spring & 25N17E-3NE & $04 / 09 / 96$ & -13.1 & -109 & - & - & 160 & 461 & 8.1 & 9.7 \\
\hline 114 & Spr. - SE Roop Mtn. & 30N11E-31SW & $04 / 10 / 96$ & -14.6 & -109 & - & - & 90 & 176 & 8.6 & 8.5 \\
\hline 115 & Cady Spring & $30 \mathrm{~N} 11 \mathrm{E}-35 \mathrm{SW}$ & $04 / 10 / 96$ & -14.7 & -111 & - & - & 85 & 182 & 8.2 & 10.5 \\
\hline 116 & Spr. - SE of Otis Canyon & $26 \mathrm{~N} 15 \mathrm{E}-10 \mathrm{NE}$ & $04 / 10 / 96$ & -12.7 & -100 & - & - & 40 & 86 & 8.4 & 12.3 \\
\hline 117 & Creek - SE of Otis Canyon & 26N15E-10NE & $04 / 10 / 96$ & -13.5 & -105 & - & - & 22 & 51 & 7.7 & 11.3 \\
\hline 118 & Cowboy Joe Spring & $26 \mathrm{~N} 16 \mathrm{E}-27 \mathrm{SW}$ & $04 / 10 / 96$ & -14.0 & -112 & - & - & 92 & 213 & 7.4 & 12.3 \\
\hline 119 & Spr. - NE side of Eagle Lake & $32 \mathrm{~N} 12 \mathrm{E}-5 \mathrm{SW}$ & $05 / 28 / 95$ & -15.2 & -116 & - & - & 70 & 165 & - & 17.0 \\
\hline 124 & Spencer Creek & $28 \mathrm{~N} 17 \mathrm{E}-16 \mathrm{SW}$ & $04 / 16 / 96$ & -12.5 & -101 & - & - & - & - & - & - \\
\hline 128 & JDS Wetlands - surface water & $27 \mathrm{~N} 15 \mathrm{E}-13 \mathrm{SW}$ & $06 / 10 / 96$ & -9.9 & .95 & - & - & - & 1340 & 9.7 & 26.1 \\
\hline
\end{tabular}


Table 3. Precipitation Data

\begin{tabular}{lllcccc}
\hline $\begin{array}{l}\text { Sample } \\
\text { Number }\end{array}$ & $\begin{array}{l}\text { Sample } \\
\text { Location }\end{array}$ & $\begin{array}{c}\text { Collection } \\
\text { Date }\end{array}$ & $\begin{array}{c}\text { Type of } \\
\text { Precipitation }\end{array}$ & $\begin{array}{c}\text { Amount of } \\
\text { Precipitation } \\
\text { (centimeters) }\end{array}$ & $\begin{array}{c}\delta^{18} \text { O } \\
\text { (SMOW) }\end{array}$ & $\begin{array}{c}\text { SD } \\
\text { (SMOW) }\end{array}$ \\
\hline & & & & & & \\
022 & Susanville & $06 / 06 / 95$ & rain & n.d. & -18.9 & -150 \\
020 & Doyle & $06 / 07 / 95$ & rain & 0.4 & -17.7 & -139 \\
019 & Doyle & $06 / 16 / 95$ & rain & 0.3 & -19.3 & -148 \\
069 & Susanville & $11 / 27 / 95$ & rain & 0.8 & -6.9 & -53 \\
070 & Herlong & $11 / 27 / 95$ & rain & 0.4 & -8.0 & -64 \\
071 & Herlong & $12 / 19 / 95$ & rain & 4.6 & -10.2 & -85 \\
072 & Herlong & $01 / 23 / 96$ & rain & 3.3 & -11.8 & -91 \\
073 & Herlong & $01 / 24 / 96$ & snow & $20^{\dagger}$ & -22.8 & -171 \\
074 & Susanville & $01 / 24 / 96$ & snow & $8^{\dagger}$ & -12.6 & -93 \\
081 & Constantia & $02 / 03 / 96$ & snow & $20^{\dagger}$ & -15.0 & -117 \\
084 & Laufman Camp & $02 / 03 / 96$ & snow & $19^{\dagger}$ & -16.0 & -124 \\
085 & Gold Run Rd. & $02 / 03 / 96$ & snow & $15^{\dagger}$ & -14.4 & -111 \\
086 & E. Shaffer Mtn. & $02 / 03 / 96$ & snow & $5^{\dagger}$ & -14.5 & -111 \\
088 & Ft. Sage Mtns. & $02 / 03 / 96$ & snow & $5^{\dagger}$ & -15.8 & -123 \\
120 & Herlong & $02 / 09 / 96$ & rain & 2.5 & -16.0 & -126 \\
150 & Herlong & $08 / 13 / 96$ & rain & 7.1 & -4.4 & -36 \\
\hline & & & & & & \\
\hline
\end{tabular}

n.d. = not determined

' reported as centimeters of snowfall, measured on the ground (not equivalent to rainfall)

Table 4. Evaporation Experiment Data

\begin{tabular}{lcccccccc}
\hline $\begin{array}{c}\text { Sample } \\
\text { Number }\end{array}$ & Date & $\begin{array}{c}\text { Time } \\
\text { (hours) }\end{array}$ & $\begin{array}{c}\text { Volume } \\
\text { (gallons) }\end{array}$ & $\begin{array}{c}\text { Water } \\
\text { Level } \\
(\mathrm{cm})\end{array}$ & $\begin{array}{c}\text { Fraction } \\
\text { Remaining } \\
(\%)\end{array}$ & $\begin{array}{c}\delta^{18} \mathrm{O} \\
(\%)\end{array}$ & $\begin{array}{c}\delta \mathrm{O} \\
(\%)\end{array}$ & $\begin{array}{c}\text { Evaporation } \\
\text { Rate } \\
(\mathrm{cm} / \text { day) }\end{array}$ \\
\hline & & & & & & & & \\
154 & $7 / 31 / 96$ & 0.0 & 30.0 & 14.0 & 100.0 & -14.0 & -117 & - \\
155 & $8 / 05 / 96$ & 120.0 & 21.0 & 10.2 & 72.7 & -4.1 & -80 & 0.76 \\
156 & $8 / 06 / 96$ & 143.0 & 15.0 & 8.3 & 59.1 & -1.8 & -71 & 1.95 \\
157 & $8 / 07 / 96$ & 173.5 & 12.5 & 6.4 & 45.5 & +1.7 & -58 & 1.51 \\
158 & $8 / 08 / 96$ & 195.5 & 11.0 & 5.7 & 40.9 & +3.9 & -46 & 0.69 \\
\hline
\end{tabular}

Fraction remaining was estimated from water level data. 
Table 5. Tritium Data

\begin{tabular}{|c|c|c|c|c|c|c|}
\hline $\begin{array}{l}\text { Sample } \\
\text { Number }\end{array}$ & Sample ID & Location & Date & $\begin{array}{l}\text { Well } \\
\text { Depth } \\
\text { (ft) }\end{array}$ & $\begin{array}{c}\text { Perf. } \\
\text { Interval } \\
\text { (ft) }\end{array}$ & $\begin{array}{c}\text { Tritium } \\
\text { Concentration } \\
(T U \pm 2 \sigma)\end{array}$ \\
\hline \multicolumn{7}{|c|}{ Groundwaters } \\
\hline 023 & W of Herlong & $26 \mathrm{~N} 16 \mathrm{E}-3 \mathrm{NW}$ & $07 / 05 / 95$ & 80 & $64-80$ & $0.4 \pm 0.1$ \\
\hline 025 & S of Doyle & $25 \mathrm{~N} 17 \mathrm{E}-29 \mathrm{NE}$ & $07 / 06 / 95$ & 80 & $54-80$ & $4.7 \pm 0.4$ \\
\hline 029 & NE of Herlong Jct. & $26 \mathrm{~N} 16 \mathrm{E}-16 \mathrm{NW}$ & $07 / 07 / 95$ & 75 & $55-75$ & $0.3 \pm 0.1$ \\
\hline 030 & E of Doyle & 25N17E-4SW & $08 / 08 / 95$ & 350 & $250-350$ & $0.9 \pm 0.2$ \\
\hline 040 & Wendel-Amedee-2 & $28 \mathrm{~N} 16 \mathrm{E}-8 \mathrm{NE}$ & $08 / 11 / 95$ & 1058 & $312-1047$ & $0.2 \pm 0.1$ \\
\hline 041 & Lee Road & 29N16E-30NE & $08 / 11 / 95$ & 400 & - & $0.3 \pm 0.1$ \\
\hline 042 & SLAD UBG-4-MWA & $28 \mathrm{~N} 17 \mathrm{E}-21 \mathrm{NW}$ & $08 / 23 / 95$ & 97 & $76-96$ & $0.5 \pm 0.2$ \\
\hline 057 & SIAD PSW \#2 & $27 N 16 E-36 S E$ & $11 / 14 / 95$ & 700 & $167-655$ & $\overline{0 . \overline{0}} \pm 0.5$ \\
\hline 060 & SLAD PSW \#9 & $26 \mathrm{~N} 16 \mathrm{E}-2 \mathrm{NE}$ & $11 / 14 / 95$ & 530 & $220-520$ & $0.2 \pm 0.1$ \\
\hline \multicolumn{7}{|c|}{ Surface Runoff } \\
\hline 004 & East Canyon Creek & $26 \mathrm{~N} 15 \mathrm{E}-6 \mathrm{SW}$ & $06 / 17 / 95$ & - & - & $9.2 \pm 0.6$ \\
\hline 014 & Susan River & 29N11E-6SE & $06 / 22 / 95$ & - & - & $5.7 \pm 0.5$ \\
\hline
\end{tabular}

Table 6. Noble Gas Data

\begin{tabular}{lcccccccc}
\hline & $\begin{array}{c}\text { Recharge } \\
\text { Altitude } \\
(\mathrm{m})\end{array}$ & $\begin{array}{c}{ }^{4} \mathrm{He} \\
(\mathrm{cc} \text { STP/g) }\end{array}$ & $\begin{array}{c}{ }^{20} \mathrm{Ne} \\
(\mathrm{cc} \text { STP/g) }\end{array}$ & $\begin{array}{c}{ }^{40} \mathrm{Ar} \\
(\mathrm{cc} \text { STP/g) }\end{array}$ & $\begin{array}{c}{ }^{84} \mathrm{Kr} \\
(\mathrm{cc} \text { STP/g) }\end{array}$ & $\begin{array}{c}{ }^{132} \mathrm{Xe} \\
(\mathrm{cc} \text { STP/g) }\end{array}$ & $\begin{array}{c}\text { Excess } \\
\text { Air } \\
(\mathrm{cc} / \mathrm{cc})\end{array}$ & $\begin{array}{c}\text { Recharge } \\
\text { Temp. } \\
\left({ }^{\circ} \mathrm{C}\right)\end{array}$ \\
\hline & & & & & & & & \\
PSW \#2 & 1200 & $1.00 \times 10^{-7}$ & $1.87 \times 10^{-7}$ & $3.49 \times 10^{-4}$ & $4.53 \times 10^{-8}$ & $3.05 \times 10^{-9}$ & $1.8 \times 10^{-3}$ & $10.4 \pm 0.3$ \\
PSW \#9 & 1200 & $1.76 \times 10^{-7}$ & $1.97 \times 10^{-7}$ & $3.35 \times 10^{-4}$ & $4.28 \times 10^{-8}$ & $2.83 \times 10^{-9}$ & $2.7 \times 10^{-3}$ & $13.3 \pm 0.3$ \\
\hline
\end{tabular}


Table 7. Linear Flow Rates for Vertical Infiltration of Groundwater

\begin{tabular}{|c|c|c|c|c|c|c|}
\hline $\begin{array}{l}\text { Sample } \\
\text { Number }\end{array}$ & $\begin{array}{l}\text { Avg. Well } \\
\text { Perforation } \\
\quad(\mathrm{ft})\end{array}$ & $\begin{array}{l}{ }^{14} \mathrm{C} \\
\text { (pmc) }\end{array}$ & $\begin{array}{c}{ }^{14} \mathrm{C} \text { age } \\
\left(\mathrm{A}_{\circ}-100 \mathrm{pmc}\right)\end{array}$ & $\begin{array}{c}\text { Linear Flow } \\
\text { Velocity }(\mathrm{ft} / \mathrm{yr}) \\
\left(\mathrm{A}_{\mathrm{o}}-100 \mathrm{pmc}\right)\end{array}$ & $\begin{array}{c}{ }^{14} \mathrm{C} \text { age } \\
\left(\mathrm{A}_{0}-85 \mathrm{pmc}\right)\end{array}$ & $\begin{array}{l}\text { Linear Flow } \\
\text { Velocity }(\mathrm{ft} / \mathrm{yr}) \\
\left(\mathrm{A}_{\mathrm{o}}-85 \mathrm{pmc}\right)\end{array}$ \\
\hline $006 *$ & 140 & 83.0 & 1540 & 0.0909 & 196 & 0.7143 \\
\hline $009 *$ & 56 & 46.7 & 6290 & 0.0089 & 4950 & 0.0113 \\
\hline $013 *$ & 110 & 54.6 & 5020 & 0.2193 & 3670 & 0.0299 \\
\hline 023 & 72 & 63.6 & 3740 & 0.0192 & 2400 & 0.0300 \\
\hline $029 *$ & 65 & 83.8 & 1460 & 0.0445 & 117 & 0.5556 \\
\hline $030 *$ & 300 & 74.6 & 2420 & 0.1239 & 1080 & 0.2783 \\
\hline $032 *$ & 119 & 62.0 & 3950 & 0.0301 & 2610 & 0.0456 \\
\hline $038 *$ & 1094 & 10.6 & 18550 & 0.0590 & 17210 & 0.0636 \\
\hline $039 *$ & 130 & 79.9 & 1850 & 0.0701 & 511 & 0.2544 \\
\hline $040 *$ & 680 & 10.0 & 19030 & 0.0357 & 17690 & 0.0384 \\
\hline $041 *$ & 400 & 17.1 & 14600 & 0.0274 & 13260 & 0.0302 \\
\hline $042 *$ & 86 & 56.8 & 4680 & 0.0184 & 3330 & 0.0258 \\
\hline 045 & 95 & 46.0 & 6420 & 0.0148 & 5080 & 0.0187 \\
\hline 046 & 97 & 30.7 & 9760 & 0.0099 & 8420 & 0.0115 \\
\hline 050 & 97 & 75.0 & 2380 & 0.0408 & 1030 & 0.0938 \\
\hline 052 & 108 & 35.0 & $8680^{\circ}$ & 0.0124 & 7340 & 0.0147 \\
\hline 057 & 411 & 17.5 & 14410 & 0.0285 & 13070 & 0.0315 \\
\hline 060 & 370 & 55.4 & 4880 & 0.0758 & 3540 & 0.1046 \\
\hline 075 & 487 & 15.0 & 15680 & 0.0311 & 14340 & 0.0340 \\
\hline 076 & 307 & 16.1 & 15100 & 0.0203 & 13750 & 0.0223 \\
\hline 077 & 610 & 13.1 & 16800 & 0.0363 & 15460 & 0.0395 \\
\hline 078 & 179 & 23.4 & 12010 & 0.0149 & 10660 & 0.0168 \\
\hline 079 & 308 & 71.4 & 2780 & 0.1106 & 1440 & 0.2137 \\
\hline 080 & 225 & 50.3 & 5680 & 0.0396 & 4340 & 0.0519 \\
\hline 082 & 455 & 45.2 & 6560 & 0.0693 & 5220 & 0.0872 \\
\hline 083 & 489 & 38.5 & 7890 & 0.0620 & 6550 & 0.0747 \\
\hline $110 \mathrm{~b} *$ & 300 & 37.0 & 8220 & 0.0365 & 6875 & 0.0436 \\
\hline 126 & 160 & 79.8 & 1870 & 0.0858 & 521 & 0.3071 \\
\hline $149^{*}$ & 155 & 37.6 & 8090 & 0.0192 & 6740 & 0.0230 \\
\hline $151 *$ & 115 & 41.3 & 7310 & 0.0157 & 5970 & 0.0193 \\
\hline $152 *$ & 104 & 59.0 & 4360 & 0.0238 & 3020 & 0.0345 \\
\hline \multicolumn{7}{|c|}{ Statistics - All Data } \\
\hline & \multirow{2}{*}{\multicolumn{2}{|c|}{$\begin{array}{l}\text { mean flow velocity } \\
\text { median flow velocity }\end{array}$}} & & 0.0419 & & 0.1071 \\
\hline & & & & 0.0311 & & 0.0384 \\
\hline & \multicolumn{2}{|c|}{ maximum value } & & 0.1239 & & 0.7143 \\
\hline & \multicolumn{2}{|c|}{ minimum value } & & 0.0088 & & 0.0113 \\
\hline & \multicolumn{6}{|c|}{ Statistics - Samples from Recharge Areas Only } \\
\hline & \multicolumn{3}{|c|}{ mean flow velocity } & 0.0417 & & 0.1445 \\
\hline & \multicolumn{2}{|c|}{ median flow velocity } & & 0.0301 & & 0.0384 \\
\hline & \multicolumn{2}{|c|}{ maximum value } & & 0.1239 & & 0.7143 \\
\hline & \multicolumn{2}{|c|}{ minimum value } & & 0.0088 & & 0.0113 \\
\hline
\end{tabular}


Table 8. Linear Flow Rates for Horizontal Infiltration of Groundwater along the Sierra Nevada Range

\begin{tabular}{|c|c|c|c|c|c|c|}
\hline $\begin{array}{l}\text { Sample } \\
\text { Number }\end{array}$ & $\begin{array}{l}\text { Horizontal } \\
\text { Distance } \\
\text { (ft) }\end{array}$ & $\begin{array}{c}{ }^{14} \mathrm{C} \\
\text { (pmc) }\end{array}$ & $\begin{array}{c}{ }^{14} \mathrm{C} \text { age } \\
\left(\mathrm{A}_{0}-100 \text { pmc }\right)\end{array}$ & $\begin{array}{c}\text { Linear Flow } \\
\text { Velocity }(\mathrm{ft} / \mathrm{yr}) \\
\left(\mathrm{A}_{\circ}=100 \mathrm{pmc}\right)\end{array}$ & $\begin{array}{c}{ }^{14} \mathrm{C} \text { age } \\
\left(\mathrm{A}_{\mathrm{o}}-85 \mathrm{pmc}\right)\end{array}$ & $\begin{array}{c}\text { Linear Flow } \\
\text { Velocity (ft/yr) } \\
\left(A_{\circ}-85 \text { pmc }\right)\end{array}$ \\
\hline 013 & 15300 & 54.6 & 5020 & 3.05 & 3670 & 4.16 \\
\hline 023 & 23000 & 63.6 & 3740 & 6.15 & 2400 & 9.60 \\
\hline 029 & 11500 & 83.8 & 1460 & 7.87 & 117 & 98.3 \\
\hline 030 & 16600 & 74.6 & 2420 & 6.85 & 1080 & 15.4 \\
\hline 032 & 17300 & 62.0 & 3950 & 4.38 & 2610 & 6.63 \\
\hline 060 & 25700 & 55.4 & 4880 & 5.26 & 3540 & 7.26 \\
\hline 079 & 26400 & 71.4 & 2780 & 9.48 & 1440 & 18.3 \\
\hline 080 & 26400 & 50.3 & 5680 & 4.65 & 4340 & 6.09 \\
\hline 082 & 26400 & 45.2 & 6560 & 4.02 & 5220 & 5.06 \\
\hline 083 & 26400 & 38.5 & 7890 & 3.35 & 6550 & 4.03 \\
\hline \multirow[t]{11}{*}{126} & 27600 & 79.8 & 1870 & 14.8 & 521 & 53.0 \\
\hline & \multicolumn{6}{|l|}{ Statistics } \\
\hline & mean flow & elocity & & 6.35 & & 20.7 \\
\hline & median flo & velocity & & 5.26 & & 7.26 \\
\hline & maximum & & & 14.8 & & 98.3 \\
\hline & minimum & & & 3.05 & & 4.03 \\
\hline & \multicolumn{6}{|c|}{ Qutliers omitted (samples 029 and 126; $A_{\circ}-85$ pmc data only) } \\
\hline & \multirow{3}{*}{\multicolumn{2}{|c|}{$\begin{array}{l}\text { mean flow velocity } \\
\text { median flow velocity } \\
\text { maximum value }\end{array}$}} & & - & & 8.51 \\
\hline & & & & - & & 6.63 \\
\hline & & & & - & & 18.3 \\
\hline & \multicolumn{2}{|c|}{ minimum value } & & - & & 4.03 \\
\hline
\end{tabular}




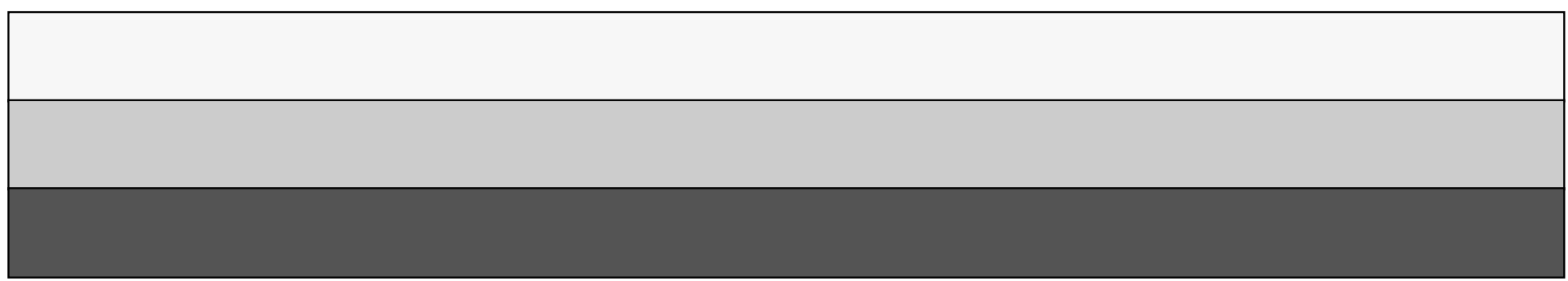

